Historic, Archive Document

Do not assume content reflects current scientific knowledge, policies, or practices. 


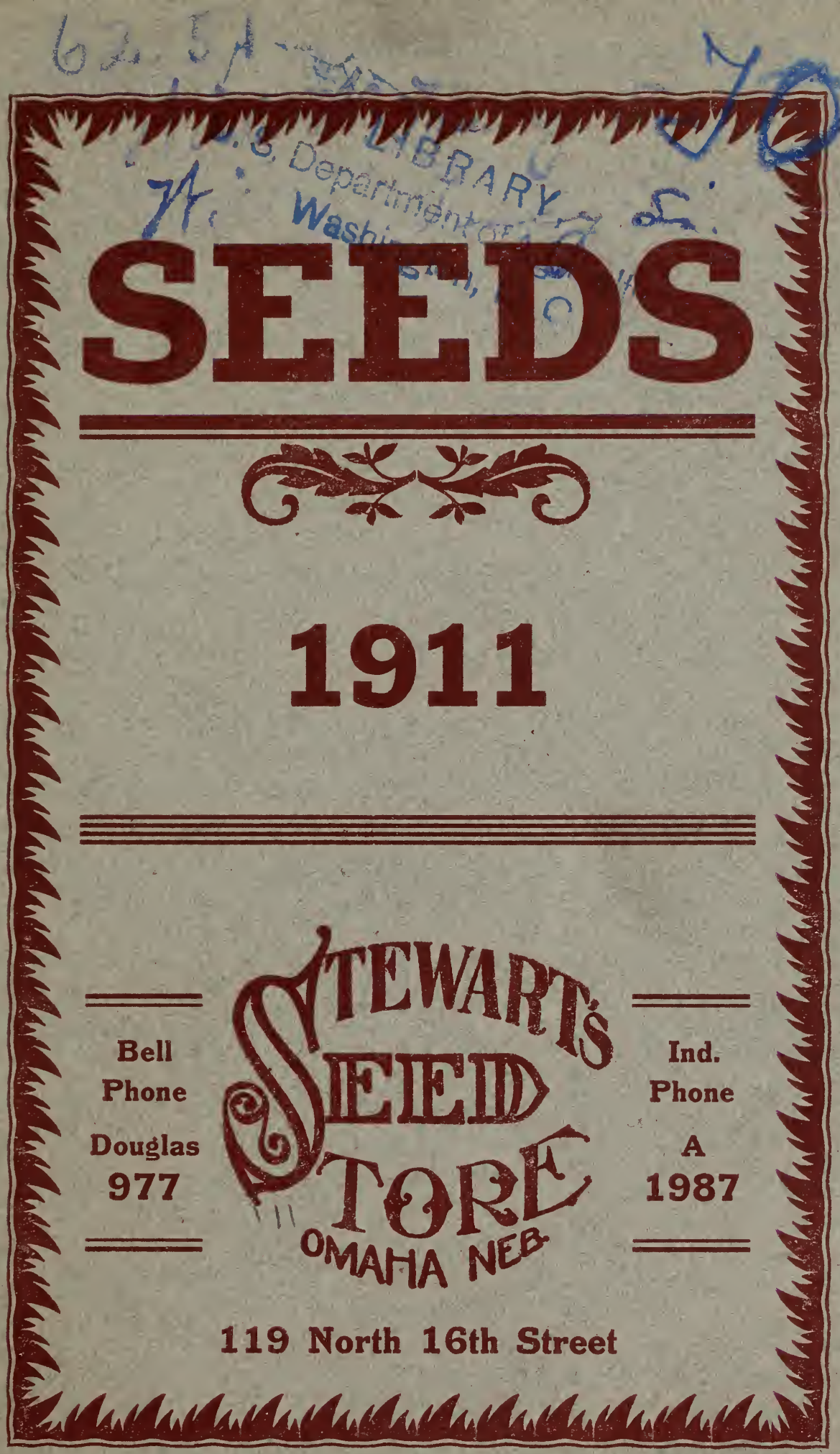




\section{TO OUR TRADE AND CUSTOMERS}

We wish to sincerely extend our thanks for your valued patronage, which each year has made our ANCHORAGE with you stronger, thereby affording us better advantages to supply you with your necessary requirements. We have spared no expense to secure the best stocks. The past season was a good and prosperous one, and, notwithstanding the unusual drouth which was World-wide in its scope, thereby making many crops extremely short, so much so that there is hardly enough to replenish for Seeding purposes, notably PEAS, and many standard varieties of Grass Seed. With all these conditions, we are in a position to fulfill your wants to the very letter.

Having also enlarged our trial grounds last season, we are in a better position to supply you with a choice lot of Dahlias, Perennials and Shrubbery, to which we call your special attention.

Again we thank you for your courtesy, and trusting that we. may have the pleasure of supplying you with your necessary requirements for the coming season, which will have our due and prompt considerations.

\section{FLOWER ARD VEGETABLE SEEDS BY MAIL POSTPAID}

\section{NOVELTIES NOT INCLUDED IN THIS OFFER}

3 Packets, 10 Cents

8 Packets, 25 Cents
17 Packets, 50 Cents

35 Packets, $\$ 1.00$

One packet Peas, Beans or Corn count as two packets.

If bulk seeds are ordered by mail, add 8 cents per quart or 8 cents per pound for postage.

TERMS: Cash with order. Remittance may be made at our risk by draft, money order, cash by express or registered letter, or clean postage stamps. Express money orders are always safe, and in case of loss quick adjustment can be made. 


\section{ORDBR BHAET FOR STEWART'S HIGH GRADE SEED Stewart's Seed Store 119 North 16th Street}

Folease write your name and address distinctly and in full with each order. Old Customers who have moved since last season will please state their former address also.

"Read Suggestions to Customers" on first page o

Catalogue. Extra order sheets and return envelopes on application.

Name

\section{Write Plainly}

Post Office

County

State

Express Office ( $\begin{gathered}\text { If different } \\ \text { from }\end{gathered}$ P. 0.

Please Ship by
Amount Enclosed

$\$$

NOTICE: Our terms are cash with order which may be sent by draft, money order or registered letter. Postage stamps may be sent if more convenient. Shipping C. O. D. adds an unnecessary expense.

Date 1911
QUANTITY or NUMBER
NAME OF SEEDS OR OTHER ARTICLES WANTED

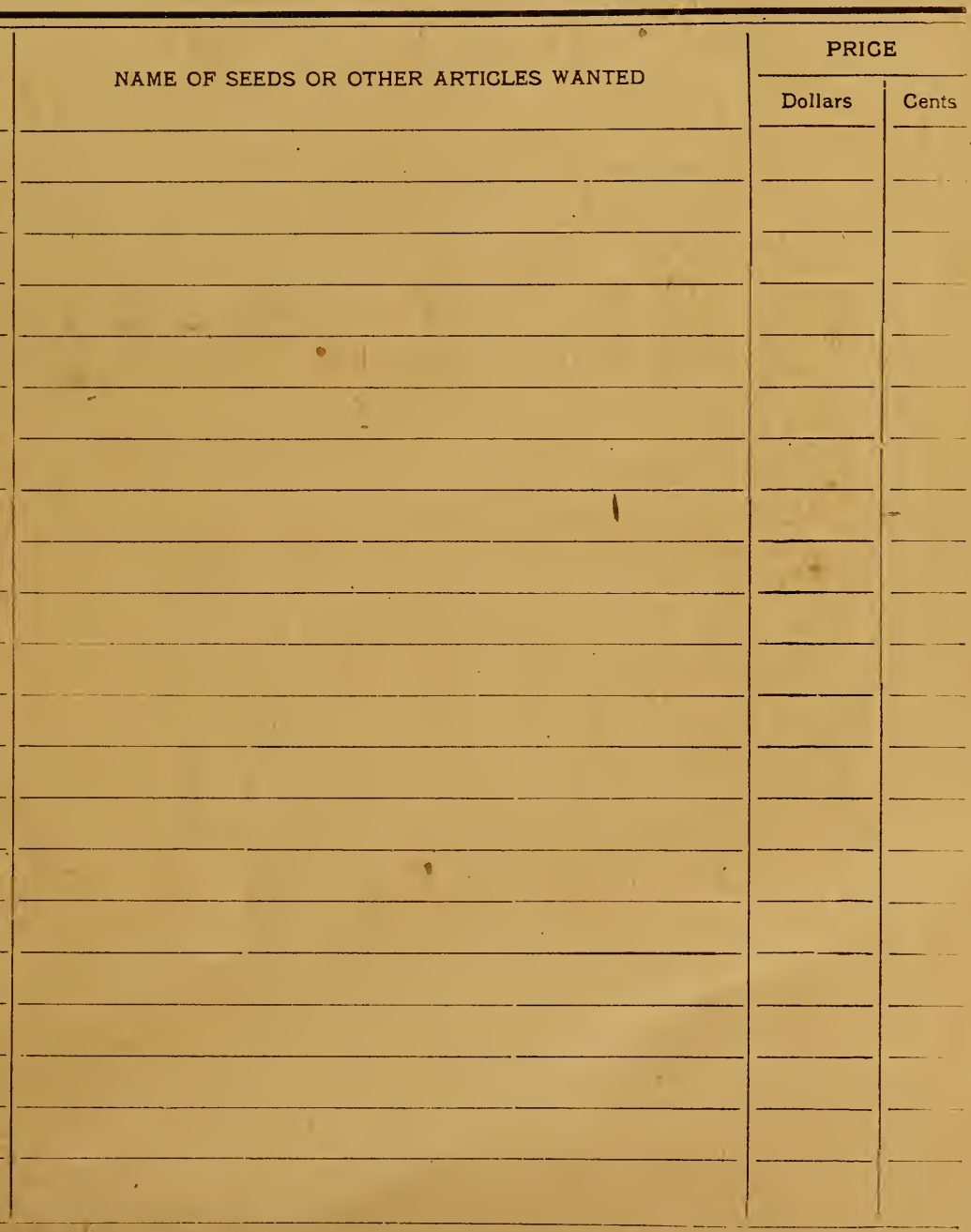





\section{SEED NOVELTIES AHD SPECIALTIES FOR 1911}

Novelties are usually the most interesting to customers, no matter how many favorites they may have among the many standard varieties. It is our aim to offer in this department nothing but varieties of real merit and value, and such as are highly endorsed by leading specialists, farmers and growers throughout the country; hence customers are seldom disappointed in any novelty we offer. One of the uses to which our Trial Grounds, near the city, are put, is the thorough testing of all new things as soon as offered.

\section{COSMOS--LADY LENNOX}

This gigantic Cosmos is the forerunner of an entirely new type of Cosmos. It is of extraordinary size and beauty, the flowers measuring from four to five inches in diameter. Color a delightful shell-pink, lighting up beautifully at night. Pkt. 10c.

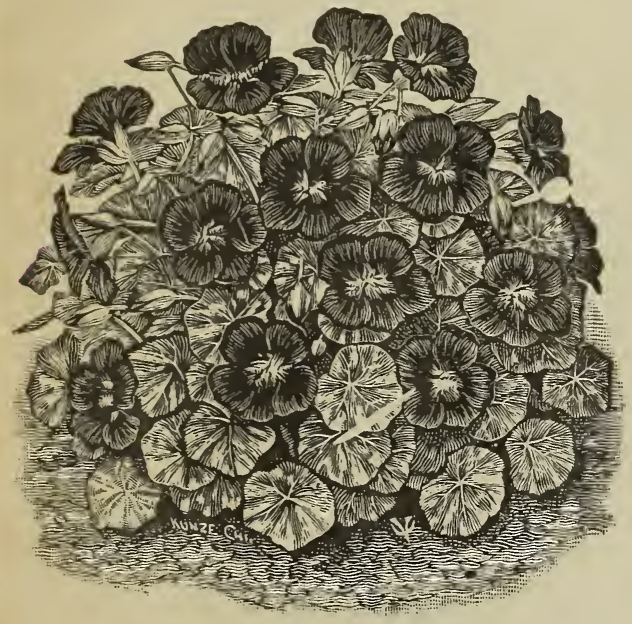

\section{NASTURTIUMS}

Queen of Tom Thumbs-(Silver Varigated Foliage)-This charming novelty produces flowers of a rich bright crimson, which forms a very pretty contrast to the silver, variegated foliage, and is a strikingly handsome and useful bedding or pot plant even before coming into bloom; it is very free flowering and produces 90 per cent. with true variegated foliage. It is very dwarf and compact, and is a great acquisition as a bedding plant. Pkt. 10c.

Queen Wilhelmina-The best of the tall (Lobb's) Nasturtiums, with variegated foliage. The leaves are marbled, streaked and relieved with pure white (not a yellowish white like some sort.) The flowers are rich, brilliant scarlet, which forms a most striking contrast with the white variegated leaves. Comes true from seed. Pkt. 10c.

\section{CHINESE KUDZU VINE \\ "JACK-AND-THE-BEAN-STALK VINE" PUERRARIA THUNBERGIANA}

If you wish a vine that will grow everywhere plant the Chinese Kudzu. It will flourish where nothing else will grow, and will last for many years. The large bold leaves of the brightest green, afford a dense shade. Its greatest feature is its wonderfuly strong growth which makes it invaluable for covering arbors, fences, porches, dead or old trees, etc. The Kudzu Vine is a native of China, where it is grown not only for the beauty of the plant but also for the edible value of its roots. The vine is hardy, grows fifty feet if permiited, and is well filled with dense foliage to the ground. Pkt. $10 \mathrm{c}$.

\section{NEW SPENCER SWEET PEAS}

The "Spencer" Sweet Peas are distinguished for their gigantic size, usually measuring two inches across; the bold, erect standards are uniformly waved, crimpled and fluted in exquisite fashion; the charming blendings of the harmonious colors; the exceedingly long flower stems, which makes them unexcelled for cutting; the great profusion of flowers and the large number of flowers on the stem, usually three to four. The following seven varieties comprise our collection of the Grand New Orchid Flowered Sweet Pea:

\section{NEW SWEET PEAS}

Apple Blossom - (Spencer) - Crimson, pink on white shaded.

King Edward VII-(Spencer) $-A$ dark, rich red of Spencer type.

Mrs. Walter W right-(Spencer) - New, a beautiful mauve of Spencer form.

Mrs. Hard Castle Sykes-New, a blush pink of large size.
Princess Alice (Spencer)-A lavender Spencer.

Miss Millie Maslin--Rosy crimson.

Princess Katherine (Spencer) - $A$ black seeded, white.

Any of the above at $10 \mathrm{c}$ per pkt.; 7 pkts. for 50c. Mixed colors, including above, $10 \mathrm{c}$ per pkt. 


\section{SEED NOVELTIES AND SPECIALTIES FOR 1911}

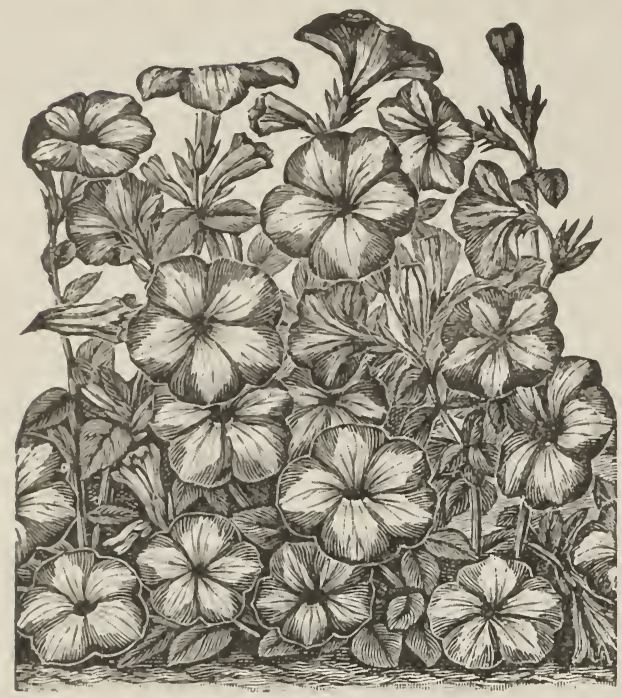

HOWARD STAR PETUNIAS

From the center starts the points of a five-rayed star, which broadens half way up, narrowing to a point at the margin of the flower. The plants are free growers, branching freely and attaining an average height of 18 inches, by 24 inches in diameter. They are remarkably prolific bloomers, single plants often having fifty fully expanded flowers at a time. Pkt. 10c.

\section{GYPSOPHILA ELEGANS ALBA GRANDIFLORA}

Every garden should have a line of it for cutting It comes up and blooms in a few weeks' time, and several sowings should be made during the season to keep up a supply. Pkt. 10c.

\section{BURBANK'S DAHLIA SEED}

EVEN IF SOWN AS LATE AS MAY 2Oth DAHLIA SEEDLINGS WILL BLOOM THE FIRST YEAR - This seed is of Luther Burbank's own saving, "will produce a greater proportion of large, clear, bright colored, perfect double flowers than any be-

fore offered; 90 per cent. of good flowers can be expected." The colors are salmon, light and dark crimson, deepest purple to maroon and almost black, light straw, deepest yellow and a few white, almost of the Cactus type. Dahlias can be raised from seed and will bloom the first year. Pkt. 10c.

\section{NEW POPPY_SANTA ROSA}

This new strain combines all the delicate beauty in color of the original Shirley and Shirley types and with these the whole flower in all its petals is beautifully crimpled as illustrated.

Few garden flowers excel the Poppy in popular favor. Its freedom of growth, beauty and lovely showiness. Pkt. 10c.

\section{DWARF POPPY}

Shirley-(Snow White)-The flowers are of the greatest beauty and if a portion of them, as sometimes happens, have a slight rose tinge towards the tip of the petals, it only adds to their attractiveness. This novelty is of great merit and will become a favorite, having regard to the very simple culture needed and the wealth of bloom which the annual Poppies yield so continuously during the summer months. Pkt. 10c.

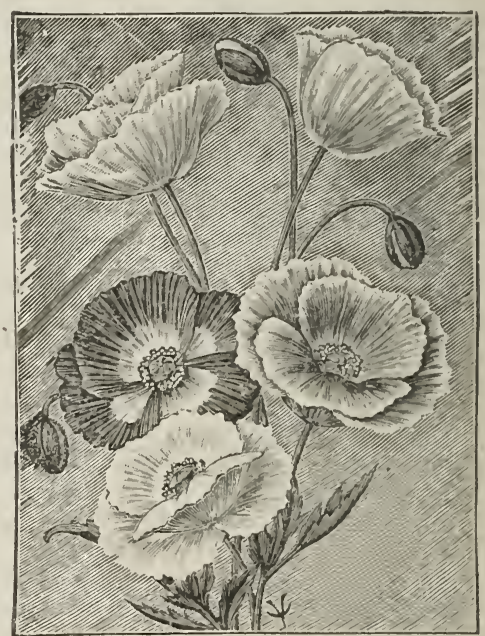

\section{POPPY "MARION"}

The one great drawback with annual Poppies, delightful as they are in their brilliant flowers, is the short duration of their flowers. This has been overcome with "Marion" which is apt to regain the favorite place the annual Poppy used to occupy in our gardens. The growth of this plant is much stronger and more vigorous in comparison to the old type. The foliage is of a rich green, stiff, of almost leathery consistency, while the flowers of a soft heliotrope color, are marvelously fringed and frilled, rendering them most valuable for bouquets. Cut, they keep in water from eight to ten days. Pkt. 10c.

\section{BURBANK'S NEW ESCHOLTZIA CRIMSON AND GOLD}

An especially fine addition to this well known family of California Poppies. Flowers freely. Pkt. 10c. 


\title{
SEED NOVELTIES AND SPECIALTIES FOR 1911
}

\section{RADISH}

\author{
STEWART'S WHITE WONDER \\ THE BEST LONG WHITE RADISH
}

Entirely distinct, long, slender, pure white. Very early, the earliest and finest long white. It is ready for use fully as early as the Long Scarlet Short Top, with less foliage, rendering it more desirable for forcing. In the open ground the roots continue brittle, crisp and mild until they are fully as large as those of the Long Cardinal. Superior .to the finest red ones. Roots pure snowy white, four inches in length and half an inch in diameter; they retain their crispness and fresh, mild flavor until fully six inches long and an inch in diam eter. Lb. 70c, Quarter lb. 20c, Oz. 10c. Pkt. 5c.

\section{PERPETUAL CRIMSON GLOBE}

This variety has given splendid satisfaction to all who have tried it. They are of uni= form good quality, crisp and brittle, and they keep longer in a fit condition for the table than any variety we know of, hence their name Perpetual Crimson Globe. Can be sown any time of the year and will always produce good radishes fit for market early and keep in perfect shape for marketing about four weeks, or longer for home use. Pkt. 5c, Oz. 10c, Quarter lb. 20c.

\section{EARLY SWEET CORN STEWART'S HONEY DEW \\ BEST EARLY SWEET CORN IN THE WORLD}

A genuine Sweet Corn, Extra Early and larger than any other early variety. It is the most valuable early variety ever introduced and not only combines all the merits of the early varieties, but it is really superior to them all in size, quality and yield. It can be planted fully as early as the Adams, for the young plants withstand slight frosts, while the other varieties are tender, and the seed will not rot if planted before the soil becomes warm. The stalks grow about five feet high and are very vigorous, generally bearing two well developed ears to the stalk, large for an early Corn. Pkt. 5c, Pt. 15c, Qt. 25c.

\section{GOLDEN BANTAM}

A new variety of Sweet Corn which many people consider the richest and sweetest of all corns. Some of our customers are now planting this corn at regular intervals during the season, so that they may have it for table use continually, and prefer it to all other sorts. It may be planted thickly and as late as July 17 th. It is a medium early variety and yields very heavily. The corn itself is of a golden 'yellow color which at first gives one an impression of field corn; however, as soon as tasted there is an immediate call for more. Our seed is raised from the originator's stock and has been selected specially for table quality. Pkt. 10c, Pt. 15c, Qt. 25c.

\section{THE DAVIS PERFECT CUCUMBER}

An excellent Cucumber for both outdoor use and forcing. It is carefully selected strain of the extra long White Spine type made by a veteran outdoor greenhouse grower of cucumbers. Its valuable points are length, slimness and its dark green color. It is a very vigorous sort and resists blight longer than most long sorts. Pkt. 10c, Oz. 15c, Quarter lb. $50 \mathrm{c}$, lb. $\$ 1.50$.

\section{PEPPER}

MANGUM DULCE

The largest of all Sweet Peppers; larger than Chinese Giant. Pkt. 10c.

Hardy Perennials and Summer Bulbs-(See pages 35 to 39.) 


\section{VEGETABLES}

\section{ASPARAGUS}

ONE OUNCE WILL SOW FORTY FEET OF ROW

Culture-Sow seeds in spring, in drills about twelve inches apart. Thin out seedlings leaving only the strongest. At one or two years transplant to permanent beds.

COLOSSAL, the standard variety

Pkt. Oz. Lb.

PALMETTO a desirable bright green variety .........

Two-year-old roots, $2.0 \mathrm{c}$ per doz., \$1.50 per 1100

One-year-old roots, 1.5 per doz., $\$ 1.00$ per $1(0)$

\section{BEETS}

ONE OUNCE WILL SOW FIFTY FEET OF ROW, FOUR TO SIX POUNDS FOR AN ACRE

Culture-Sow as early as possible in the spring and every two weeks after for a succession up to the first week in July. The soil should be light and well manured. Sow in drills about flifeen inches apart and thin from four to six inches after they are well up.

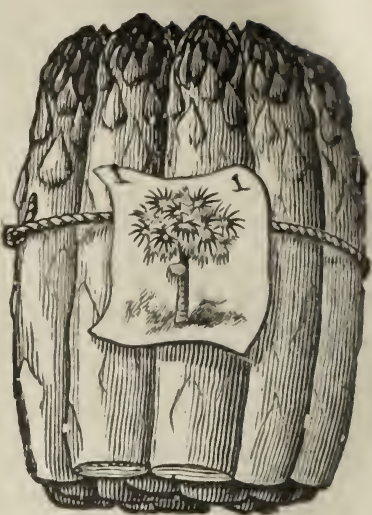

ASPARAGUS

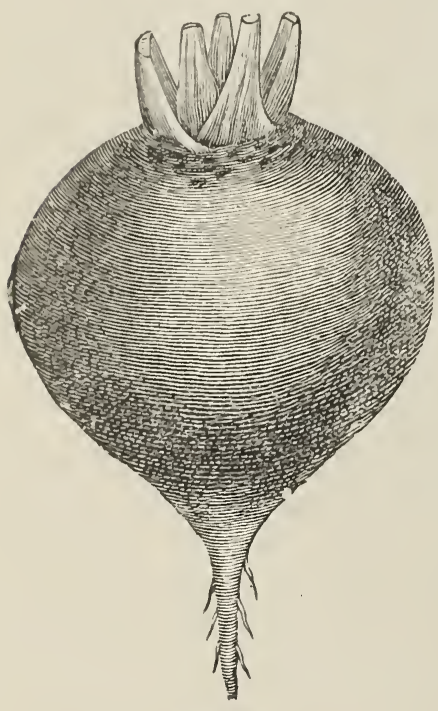

BEET

Farly Exyptian Turuip-Bults are half globular or flattened at the poles; skin smooth, leaves red and green, flesh quite dark Pkt. .jc, ${ }^{1} 4 \mathrm{lb}$. 1.ic, lb. jllc.

Lxtra Larly Eclipse, 40 bays-The bulbs are perfect glodes. blood colored, and develope with astonishing rapidity. Pkt. jc, oz. IIr $1_{4} \mathrm{lb} .20 \mathrm{c}, \mathrm{lb}$. (1)c.

Larly Blood Red Turnip-It is the best turnip-shaped bet for family use, all things considered, and we recommend it to all gaiden ers. Pkt. $5 \mathrm{c}, 0 \mathrm{z}$. $11 \mathrm{cc}, 1 \frac{1}{4} \mathrm{lb}$. $20 \mathrm{c}, \mathrm{lb}$. $70 \mathrm{c}$.

betroit Blood Red Turnip-14 lb. 20)c, lb. 7(loc

Half Lon: Blood ried Dark blood-red, skin smooth; habits much earlier in maturity than the old Long Blood, and only half its length. Pkt. 5c, oz. $10 \mathrm{c},{ }^{1} 4 \mathrm{lb}$. $20 \mathrm{c}$, lb. 70c.

Swiss Chard Beet or Sea Kiale-Much superior to the common Beet for greens and equal to spinach Sown early in the spring. it makes rapid srowth of leaves, and is fit for greens sooner than any other variety. Pkt. $5 \mathrm{c}, \mathrm{oz} .10 \mathrm{c}, 1_{4}$ lb. $20 \mathrm{c}, 1 \mathrm{~b} .70 \mathrm{c}$.

\section{MANGELS}

Culture - Extensively grown in all parts of the country for feeding stock. Sow in April or May, in drills three feet apart, and thin to ten inches in the row. "lf your soil is deep and mellow, try the long varieties; if shallow the round kinds will do better. No crop pays the farmer or stock raiser better than mangels; one thousand bushels to the acre is an ordinary yield, while with good culture over two thousand bushels have been grown on this amount of ground. These make the cheapest of foods for all kinds of live stock-horses, cattle, sheep, pigs, chickens, etc. Easily grown and they help to keep the stock in good condition and free from disease. Use twelve pounds of seed to the acre.

Golden Tankard-A rapidly maturing root adapted to shallow lands though doing well on every soil. Solid sugary flesh and golden foot stock. Lb. $35 \mathrm{c}, 3 \mathrm{lbs}$. $\mathrm{S} 1,(0)$.

Mammotl Long Red-Grows to an immense size and has produced five tons to an acre. Lb. $35 \mathrm{c}, 3 \mathrm{lbs} . \$ 1.00$.

\section{SUGAR BEETS FOR SUGAR MAKING AND CATTLE FOOD}

Silexian sugar-Lb. 35̄c.

Klein Wanzleben-This variety is used by the sugar factories. Lb. 3ac.

SPECIAL PRICES-As prices named above are subject to change during the season we request persons desiring to purchase a large quantity to write for special quotations.

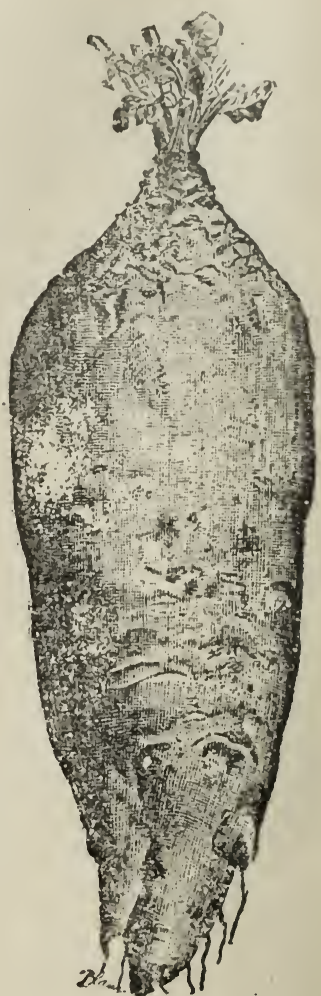

MANGEL 


\section{DWARF WAX BEANS \\ ONE QUART WILL PLANT ONE HUNDRED FEET OF ROW}

Culture-In early May, in a warm and sheltered spot, sow in drills about two inches deep and eight inches apart. Sow every two weeks for successior.

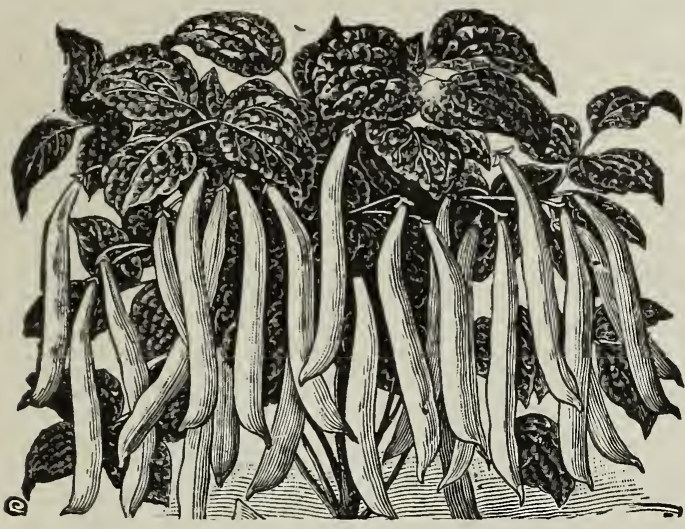

Golden Wax-Maturing for the table in about thirty-five days from germination. A flat podded sort, but probably the best known of the yellow. Pkt. 5c, qt. 30c, pk. $\$ 1.60$.

Dwarf German Wax, Black Seed-Pods round, meaty, curved, and borne in bunches, ready for the table in about forty days from germination. Pkt. 5c, qt. 30c, pk. $\$ 1.50$.

White Wax-Pods broad, flat, yellow, semi-transparent when boiled, of delicate flavor, maturing for table thirty-seven days from germination. Pkt. 5c, qt. 30c, pk. $\$ 1.50$.

Wardwell's Dwarf Kidney Wax-Rust proof, vigorous, pods large, showy, tender and stringless, excellent flavor, and good for either snap or shell. Pkt. 5c, qt. 30c, pk. $\$ 1.50$.

\section{BEANS \\ DWARF OR SNAP BEANS}

Stringless Green Pod-Surpasses all others in crisp, tender flavor. The finely shaped long green pods are absolutely stringless. Pkt. 5c, qt. 30c, pk. \$1.75.

Early Mohawk-Very early and will stand more cold weather than most bush varieties. It can be planted earlier, and will furnish beans fit for use, before any other kind. Pkt. 5c. qt. $30 \mathrm{c}$, pk. $\$ 1.50$.

Extra Early Red Valentine-Color of pods light green and semi-transparent; round and slightly curved. Succulent, prolific and quite free from strings, continuing long in edible condition. Pkt. 5c, qt. 30c, pk. \$1.50.

Long Yellow Six Weeks-A leading market sort. Pkt. 5c, qt. 30c, pk. \$1.25.

Early Refugee or Thousand to One-Most prolific green podded sort, thick and fleshy. Pkt. 5c, qt. 30c, pk. \$1.25.

Giant Stringless Green Pod-This new Bean has a much larger and handsomer pod than the Valentine, and without any strings. It is distinct from the variety introduced as "Burpee's Stringless," as Giant has a much longer pod. The Giant stringless is earlier than the Valentines and more prolific. Qt. 30c, pk. \$1.75.

Navy-The popular white Bean for baking. Qt. 25c, pk. \$1.10.

\section{DWARF LIMA BEANS}

Henderson's Bush Lima--Is at least two weeks earlier than any of the climbing Limas. producing a continuous crop from the middle of July until frost. Enormously productive. Pkt. $5 \mathrm{c}$, qt. $35 \mathrm{c}$, pk. $\$ 1.75$.

Burpee's Bush Lima-A dwarf for bush form of the true, large Lima, which is of great value. They are of perfect bush form, growing eighteen to twenty inches high, of stout and erect growth, yet branching and vigorous. Pkt. 5c, qt. 35c, pk. \$1.75.

Dreer's-Very prolific, single plants often producing 150 to 200 pods and are thick, sweet and succulent. Pkt. 5c, qt. 35c, pk. \$1.75. 


\section{POLE BEANS}

ONE QUART WILL PLANT ONE HUNDRED TO ONE HUNDRED AND FIFTY HILLS

Culture Sow as soon as the soil is warm and dry, about the end of May, in hills about four feet apart each way. Poles eight or ten feet long should be firmly set in the center of the hills before putting in the seed.

Extra Early Jersey Lima - Under favorable conditions, three or four days earlier than the large Lima. Pkt. 5c, qt. 35c, pk. \$1.75.

Large White Lima-Smaller seeded than the Jersey, not so strong in vine nor so large in pod. Otherwise excellent in quality. Pkt. 5c, qt. 35c, pk. \$1.75.

Horticultural-A showy bean, maturing in eighty days. Pods green, dashed with red. Pkt. 5c. qt. $35 \mathrm{c}$, pk. \$1.75.

Tall German Wax, Black Seed A good snap-short. Pods flat, waxy, maturing in seventy-five days from germination. Pkt. 5c, qt. 35c, pk. \$1.75.

Lazy Wife - The pods are produced in great abundance and measure from six to eight inches in length. The pods retain their rich, tender and stringless qualities until nearly ripe, and are unsurpassed in all stages. Each pod contains six to eight round white beans, which make excellent winter shell beans. Pkt. 5c, qt. 35c, pk. \$1.75.

Kentucky Wonder or Old Homestead-An old favorite with long, fleshy, deeply saddlebacked pods. Very prolific, producing an abundance of fine stringless, crisp beans until late in the season. Of best quality. Pkt. 5c, qt. 35c, pk. \$1.75.

\section{BRUSSELS SPROUTS \\ ONE OUNCE OF SEED TO ONE HUNDRED YARDS OF ROW}

A variety of the Cabbage family, possessing the peculiarity of bearing upon its stem, buds resembling minature cabbage heads. Pkt. 5c, oz. $15 \mathrm{c}$.

\section{CRESS}

Cultur. This is used as a salad. It should be sown at close of winter broadcast, or in rows at ten inches and the sowing repeated every two weeks.

Curled--Used for flavoring and as a salad. Pkt. 5c, Oz. 10c.

\section{CAULIFLOWER}

\section{ONE OUNCE WILL PRODUCE ABOUT THREE THOUSAND PLANTS}

(:ulture-Same as cabbage, except that they need a cool and moist atmosphere. As the flower heads appear, the large leaves should be broken down over them to shield them from the sun and rain.

Early Snowball - Throughout the country this is considered not only the earliest of all Cauliflower, but it is more certain to make a head than any other sort. Our stock is extra choice and cannot be excelled. Pkt. 20c. oz. \$2.25.

Extra Early Dwarf Erfurt - A very popular variety. First quality. Pkt. $15 \mathrm{c}, 1 / 4$ oz. $75 \mathrm{c}$.

Early Paris--Well known. Pkt. 10c.

Algiers - A favorite with market gardeners. Try it. Pkt. 10c, oz. 75c.

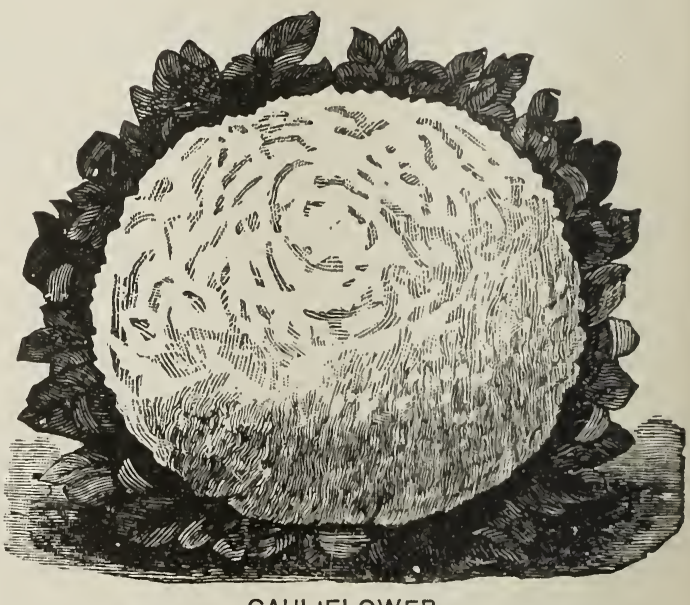

\section{CAULIFLOWER}

Dry Soil Cauliflower--This strong growing, fine and showy strain has proven reliable in many dry sections of the country, providing the soil is deep. mellow, rich and weil cultivated. It has succeeded especially in the vicinity of St. Louis, Mo., a location where most other sorts fail on account of dry weather. It produces very large broad leaves and large solid and pure white heads. Pkt. 15c, oz. \$2.50.

Open orders always filled at lowest prices. If you do not receive our price list regularly. write for them. 


\section{CABBAGE}

\section{ONE OUNCE OF SEED TO ONE HUNDRED YARDS OF ROW}

Culture-Soil for Cabbage should be a heavy loam. On such soil, well manured, excellent crops are sure tó to be grown. Sow the seed in hot-beds in February or March.

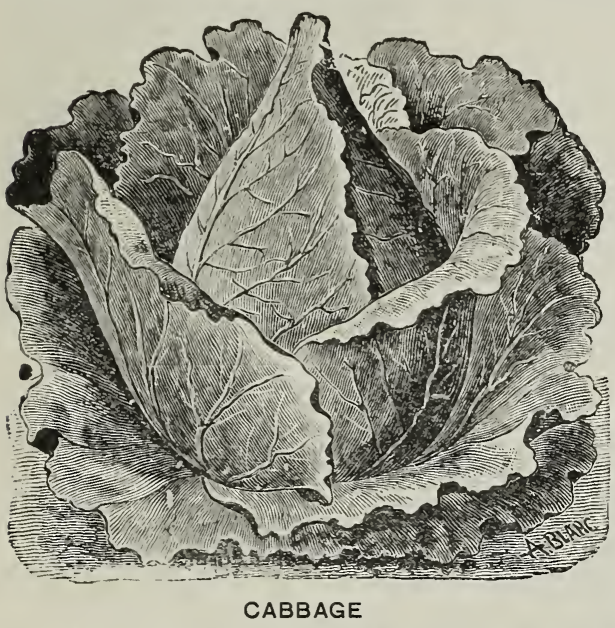

We Especially Call Ittention to (Our Fine First Early Sorts.

\section{FIRST EARLY VARIETIES}

Landreth's Earliest Cabbage-Few outside leaves and short stem. This Cabbage will do well on soil so light that success with late varieties is not possible. Pkt. 5c, oz. 30c

\section{Select Very Early Jersey Wakefeld-} Heading for market in seventy to eighty days. It is very early, short stemmed, head cone shaped. A reliable header and most excellent in all good qualities. Pkt. $5 \mathrm{c}$, oz. $25 \mathrm{c}$

Reedland Early Drumhead--To anyone wanting an early flat-headed Cabbage of reliability, we recommend the Reedland Early Drumhead as uniting all the essentials. It will do for first, second and third early, intermediate and late. Pkt. 5c, oz. 35c.

Early ${ }^{\circ}$ Summer Flathead-Average weight four pounds, sometimes six. A variety which may be planted close. Unquestionably the EARliest Flatheaded Cabbage in Cultivation. Only a day or two behind the earliest Wakefield. Pkt. 5c, oz. 25c.

\section{INTERMEDIATE RIPENERS}

New York Early Summer-Heads oval, color bluish green with lighter colored veins, stem short and stocky. Pkt. $5 \mathrm{c}$, oz. $25 \mathrm{c}$.

All the Year Around--Spring, Summer, Autum or Winter, without respect to habit or quality, it is the hardiest of Cabbages; under the heat of summer it stands unflagging. Pkt. 5c, oz. 30c.

Early Drumhead-Size large, always SOLID, few extra leaves: rather SHORT IN STEM AND WILl STAND Without BURSting. Pkt. $5 \mathrm{c}$, oz. $30 \mathrm{c}$.

Burpee's All=Head Early-The most solid variety on the list. Pkt. 5c, oz. 30c.

\section{LATE VARIETIES}

Market Gardeners' Large Late Flat Dutch-No strain is superior and few equal to this. The head is thick, broad, solid and slightly rounded on top. though the variety is what is termed a Flat-head. Pkt. 5c, oz. 25c.

Market Gardeners' Large Late Drumhead--Very choice. late, large, hardy, certain to head, and, being of heavy weight, quite productive. Pkt. 5c. oz. 25c.

Danish Ball Head-The best keeping of all winter sorts. Head round and more solid than any other cabbage known. Pkt. 5c, oz. 30c.

Red Dutch-Leaves red or purple and exclusively used for pickling. Pkt. 5c, oz. 25c.

Green Curled Savoy--The finest type of Winter Cabbage. After having been frosted it boils like marrow. The strain is not to be confounded with low priced imported seeds. Pkt. 5c, oz. 25c.

St. Louis Late Market-Oz. 30c.

USE SLUG SHOT for Cabbage Worms. It kills them. Lb. 10c, $5 \mathrm{lbs} .30 \mathrm{c}, 10 \mathrm{lbs} .50 \mathrm{c}$. 


\section{CELERY}

THREE OUNCES OF SEED TO ONE HUNDRED YARDS OF ROW

Culture-Sow'when the apple is in bloom, on a finely raked surface and cover scarcely at all, in a moist place or convenient to water, which apply freely in dry weather. When the plants are four inches more or less in height, transplant a portion into very shollow trenches, formed in well manured land, which planting repeat at inter vals of two or three weeks for succession.

Dwarf White - Hearts white and crisp. Pkt. 5c, oz. 25c.

IBosion Market-Much esteemed. Pkt. 5c, oz, 25c.

Iaris Goliten Vellow-Very easily blanched. Pkt. 5c, oz. 30c.

White P'lume-Self bleaching to a great extent. Desirable as an early sort. Pkt. jc, oz. ?.).

l'ink Plume-Stalks beautifully tinged with pink. Pkt. 5c, Oz. $25 \mathrm{c}$.

Large White-The most imposing of all varietles. Pkt. xc, oz. 25.

(iiant P'as'al A mammoth silver-white stalked variety. Pkt. jc, oz. 25:c

Turnip laooted-Grown exclusively for its roots, which are turnip shaped. Used for seasoning meats and flavoring soups. Pkt. ic, oz. $25 \mathrm{c}$.

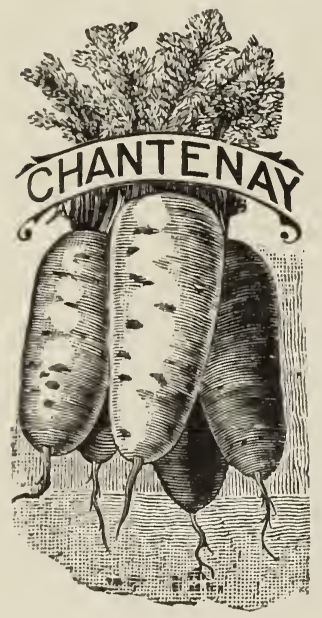

CARROT

\section{CARROTS}

\section{ONE OUNCE WILL SOW ONE HUNDRED FEET OF ROW, FOUR POUNDS FOR ONE ACRE}

Culture-For early crop, sow in spring as soon as the ground can be worked, in drills fifteen inches apart, covering one-half inch: thin plants to three or four inches apart in a row. Sow seed from the middle of April to the first of June. A light, sandy loam deeply tilled is the best. A fair average yield is 800 to $1(x)$ bushhels per acre.

Early Scarlet Horn, Blunt Rooted--Length four to five inches. Pkt. 5c, oz. 10c, 1/4 lb. 25c, lb. 75c.

Early Scarlet Horn, Pointed-Quite desirable; growth rapid; Pkt. 5c, oz. 10c, 1/4 lb. 25c, lb. 75 c.

Ox Heart-Top shaped. Color, orange red, tender, flavor excellent. Pkt. 5c, oz. 10c, 1/4 lb. 25c, lb. $75 \mathrm{c}$.

Chantenay Half=Long Scarlet-Short, thick, stump-rooted, orange. Very productive. Pkt. 5c, oz. 10c, 14 lb. 25c. lb. $75 \mathrm{c}$.

Danver's Half=Long-Admirable in color, fixed in habit. a wonderful producer. Pkt. 5c, oz. 10c. $1 / 4 \mathrm{lb} .25 \mathrm{c}, \mathrm{lb} .75 \mathrm{c}$.

Large White Belgian-Large white root with green top. Grown exclusively for feeding stock. Pkt. 5c, oz. 10c, $1 / 4 \mathrm{lb} .20 \mathrm{c}$, lb. $60 \mathrm{c}$.

Culture-Cucumbers succeed best in warm, sandy loam. They should not be planted in the open air until warm settled weather. The hills should be previously prepared by mixing thoroughly with the soil in each a shovelful of well rotted manure.

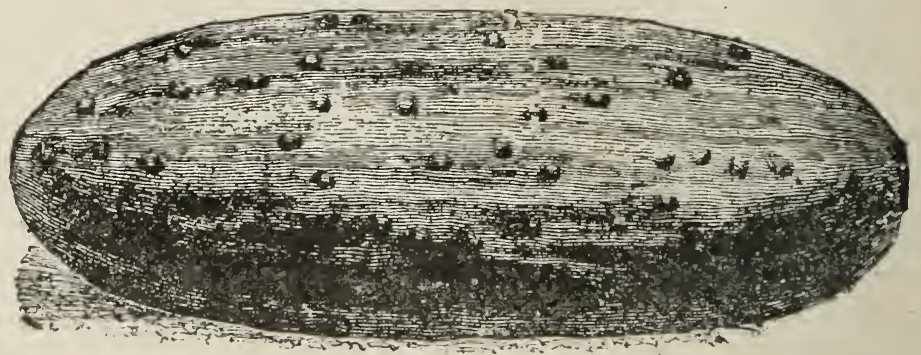

\section{CUCUMBER}

Improvel Viul, White Spine-Used almost entirely for slicing. The fruit is of good size, in quality solid and cossesses the habit of retaining its green color for a long period. Pkt. 5c, oz. 1.5c. ${ }_{4} 4 \mathrm{lb}$. 3ilc.

Jer pickle-Said to "green" better than any other variety, and to "hold color." "Size two to three inches long in sixty days. Pkt. .jc, oz. 1.je, $1_{4}$ lb. 2ic.

Bostun Jicklius-Pkt. sc, oz. 1.ic, ${ }^{4}$ lb. P.c.

Turkay long (ireen-Recommended to all who put up their own pickles. Fruit long and slim. This is not the New England Long Green, but a much superior sort. Pkt. ic, oz. 1.ic. ${ }_{4}$ lb. 2.ic.

Farly l'rame-Pkt. ic, oz. 1.ic, ${ }^{4}$ lb. 2.j.

Farly cluster-Pkt, ic, oz. 1.je, 14 lb. 2. co

Japanec. (limbilı-Climbs like a Morning Glory; bears numerous large, excellent fruir, and very desirable when young for nickles. Pkt. ic, oz. $2(1 \mathrm{c}, 14 \mathrm{lb}$. tic. [Davis Perfect Cucumber SEE NOVELTIES] 


\section{SWEET CORN}

Culture-Plant in drills four feet apart; and plants thinned out to eight or ten inches. Sow in succession every two weeks from the beginning of May until the middle of July, and by properly selecting the varieties continuous supply can be had until killed by the frost.

"Peep O' Day"- The stalk grows from three to four feet in height. The ears average about five inches in length and are of perfect form. Pt. 15c, qt. $25 \mathrm{c}$.

Extra Early Adams-Ready for table sixty-two days after germination. Not a sugar corn, but a decided acquisition so very early in the season. Pkt. $5 \mathrm{c}$, qt. 25c, pk. \$1.25.

Corey-Edible sixty days from germination. Pkt. 5c, qt. 25c, pk. \$1.25.

Extra Early Minnesota Sugar-Among the extra early Sugar Corns. Ears well made out. Pkt. 5c, qt. 25c, pk. \$1.25.

Shakers Early-Qt. 25c, pk. \$1.25.

Extra Early Crosby Sugar-This variety will produce edible ears in seventy days from germination. Pkt. $5 \mathrm{c}$, qt. $25 \mathrm{c}$, pk. $\$ 1.25$.

Mammouth White Cory....25c

Country Gentlemen........25c

Evergreen............25c

Mammouth Sugar ........25c

$\mathrm{Pk}$.

$\$ 1.00$

1.00

1.00

1.00 elties.

Golden Bantam, Honey Dew, see Nov-

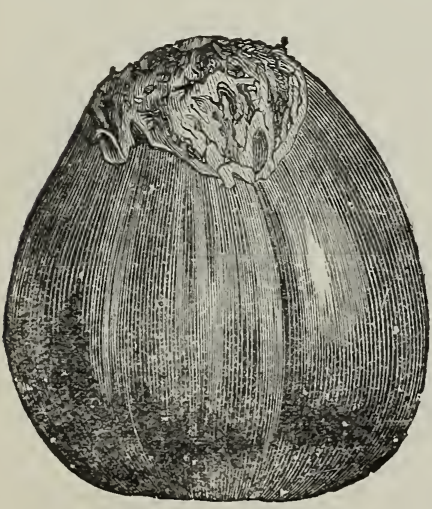

EGG PLANT

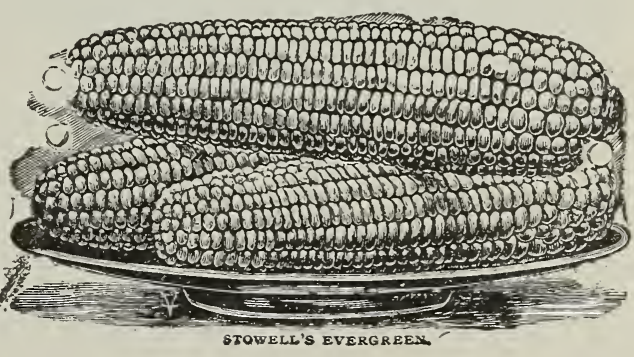

EGG PLANT OF ROW

Culture-Sow in hot-beds very early in spring and transplant when two inches high. If planted earlier they are liable to get checked by the cool nights.

New York Improved-Pkt. 5c, oz. 40c.

\section{ENDIVE}

TWO OUNCES OF SEED TO ONE HUNDRED YARDS OF ROW

Culture-Sow in the spring as soon as the earth is free from frost, and repeat up until sixty days of frost. oz. $15 \mathrm{c}$.

Moss Curled-Green and extra curled. Pkt. 5c,

\section{KALE}

ONE OUNCE OF SEED TO ONE HUNDRED YARDS OF ROW

Culture-Sow in early spring when the oak is in full leaf, and again in early autumn.

Leaves Moss Curled-Height ten inches. Pkt. 5c, oz. $15 \mathrm{c}$.

\section{KOHL-RABI \\ ONE OUNCE OF SEED TO ONE HUNDRED YARDS OF ROW}

Culture-Any good soil will produce a crop, the plants for which may be grown like Cabbage, in seed beds, for transplanting, or sown in permanent position in three foot rows.

White Vienna-Very rapid in growth, early in maturity. Pkt. 5c, oz. 20c. 


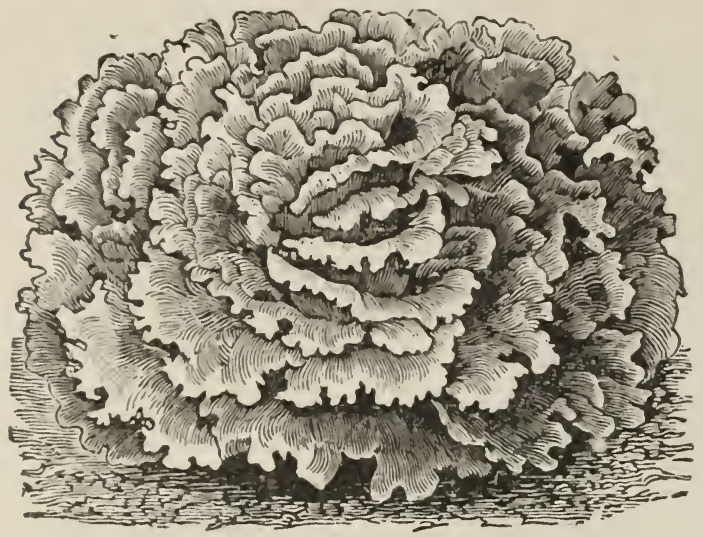

LETTUCE

LETTUCE

TWO OUNCES OF SEED TO ONE HUNDRED YARDS OF ROW

Culture-For early crops sow in hot-beds in March and set out in April.

Black Seeded Simpson-A cutting variety of unusual merit. Pkt. $5 \mathrm{c}$, oz. $15 \mathrm{c}, 1 / 4 \mathrm{lb} .40 \mathrm{c}$.

Curled Simpson--A cutting variety similar to and immediately following the Silesian. Pkt. 5c, oz. 15c, 1 1 lb. 40 c.

Virginia Solid Header Few leaves outside of the head, late to mature, but slow to shoot to seed. Pkt. 5c, oz. 25c, $1 / 4 \mathrm{lb} .75 \mathrm{c}$.

Imperial Cabbage - $A$ showy white cabbaging variety of very choice quality, uniform in character and in every particular. Pkt. 5c, oz. $15 \mathrm{c}, 1 / 4 \mathrm{lb} .30 \mathrm{c}$.

Speckled Dutch Butterhead _Compact heads, the leaves possessing the peculiarity of being irregularly dotted with spots resembling iron rust. Pkt. $5 \mathrm{c}$, oz. $15 \mathrm{c}, 1 / 4 \mathrm{lb} .40 \mathrm{c}$.

Largest of All Magnificent heads. A very large green cabbaging variety, altogether desirable, both for family and market garden. Pkt. 5c, oz. 15c, 1/4 lb. 40c.

Grand Rapids _. Strong grower, free from rot, a desirable variety for sowing in the open ground. Pkt. 5c, oz. $15 \mathrm{c}, 1 / 4$ lb. $40 \mathrm{c}$.

Heat Resisting Cos_Crisp, never wilting under the severest sun. It should be in every garden. Pkt. $5 \mathrm{c}$, oz. $15 \mathrm{c}, 1 / 4 \mathrm{lb} .40 \mathrm{c}$.

May King - It is not easily affected by cold or wet, grows very quickly and produces, even in poor soil, splendid, globular heads. Pkt. 5c, oz. $15 \mathrm{c}, 1 / 4 \mathrm{lb} .40 \mathrm{c}$.

\section{LEEK}

TWO OUNCES OF SEED TO ONE HUNDRED YARDS OF ROW

Culture-Sow when the apple is in bloom; if for transplanting, sow in close beds. To secure a full development thin out.

Musselburg-Remarkably large. Pkt. 5c, oz. $15 \mathrm{c}$.

Large American Flag_Desirable for family use. Pkt. 5c, oz. $15 \mathrm{c}$.

\section{MUSHROOM SPAWN}

Good spawn is one of the most important factors in the successful cultivation of Mushrooms, either for use on the table or for supplying the great demand on the market. The spawn sold by us is carefully made from fresh cultures of the well

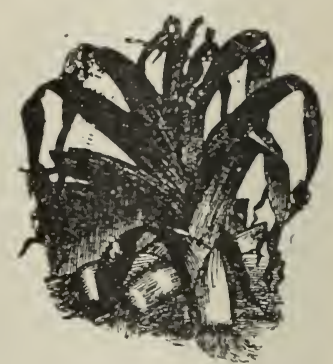

LEEK known edible Mushroom. This spawn is prepared and supplied direct to us by the most careful and efficient growers. We handle only what is known throughout the seed trade as "Pure Culture" and "English" which come in bricks weighing over one pound and which we have proved by both observation and test to be the most satisfactory in use at the present time. Brick 25c, 5 bricks $\$ 1.00$

\section{MUSTARD}

\section{FIVE OUNCES WILL SEED ONE HUNDRED YARDS OF ROW}

Culture-In the spring when the pear is in bloom, drill in rows one foot apart. To have a succession the sowing should be made every two or three weeks until October.

White Pkt. 5c, oz. 10c, lb. 25c. Brown-Pkt. 5c, oz. 10c, lb. 25c.

Lawn grass is a very voracious feeder and will not thrive and hold its beautiful dark green color and velvety appearance unless it receives a sufficient supply of suitable food. Because so few appreciate this fact is the reason there are so many poor, rusty-looking lawns. Stable manure is unpleasant to handle, ill looking and decidedly odorous, and it is also full of waste material. It contains weed seeds which are obnoxious and it often takes years to eradicate the weeds, causing an unnecessary amount of labor. All these objections are obviated by the use of our Lawn Fertilizer. 


\section{MUSK MELON OR CANTALOUPE}

TWO OUNCES OF SEED TO ONE HUNDRED YARDS OF ROW FOUR POUNDS TO THE ACRE

Culture-When the ground has become warm and dry plant eight to ten seeds to a hill. When up and all danger of insects is past, thin out to three or four.

Extra Early Citron-(FIRST in MARKeT) 60 Days. Form, half flat, fairly webbed, flesh green. The merit of this sort consists in its extra early habit. Pkt. 5c, oz. 10c, 1/4 lb. 30c, lb. \$1.00.

Extra Early Hackensack-A week or ten days earlier than the old Hackensack. Small foliage; profitable for market. Pkt. $5 \mathrm{c}$, oz. $10 \mathrm{c}$, $1 / 4$ lb. $30 \mathrm{c}, 1 \mathrm{lb} . \$ 1.00$.

Extra Early Cape May - A very early and large, round Cantaloupe; quality most excellent and exceedingly productive, fruit deeply ribbed and heavily netted, flesh deep green, tender, juicy, very sweet, foliage very small and proof against sunshine. Producing well on lightest soils. Pkt. 5c, oz. $15 \mathrm{c}, 1 / 4 \mathrm{lb} .30 \mathrm{c}, \mathrm{lb} . \$ 1.00$.

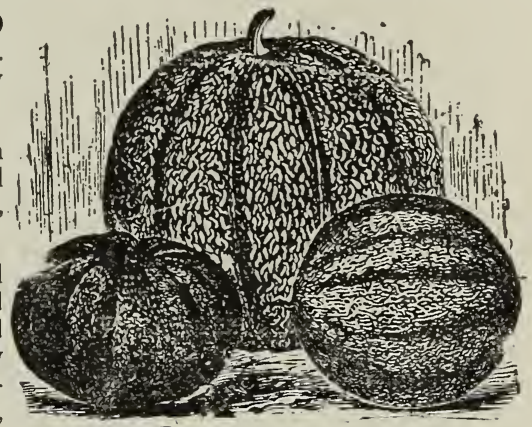

MUSK MELON OR CANTALOUPE

Emerald Gem-A very small, very early melon; form globular, flattened at the poles, ribbed, smooth, deep emerald green skin. Pkt. 5c, oz. 15c, 1/4 lb. 50c.

Rocky Ford-A Cantaloupe of great celebrity, grown in Rocky Ford, Colorado. Small in size but of very superior flavor; rind well ribbed, flesh green with a line of gold just beneath the skin. Pkt. 5c, oz. $15 \mathrm{c}, 1 / 4 \mathrm{lb}$. $40 \mathrm{c}$.

Miller's Cream -A favorite salmon-fleshed variety. Large, oval, slightly ribbed and netted; skin very dark green, very thick and sweet flavored. Pkt. $5 \mathrm{c}$, oz. $15 \mathrm{c}, 1 / 4 \mathrm{lb} .40 \mathrm{c}$.

Montreal- $\bar{A}$ showy citron, average weight ten pounds, though going up to twenty. Well ribbed and netted. Flesh deep, sugary, and green in color. Flavor fine. Suitable for heavy soil. Pkt. 5c, oz. 15c, 1/7 lb. 40c.

Paul Rose (Petoskey) - In the Paul Rose we have a successful cross of the Osage with the netted Gem, which combines the sweetness of the one with the fine netting of the other. In fact a large size Netted Gem with deep orange flesh. Pkt. $5 \mathrm{c}$, oz. $15 \mathrm{c}, 1 / 4 \mathrm{lb} .40 \mathrm{c}$.

Jenny Lind $-A$ very small, early variety, flattened at the poles, of surprising good quality, recommended for family garden, rather small for market. Pkt. $5 \mathrm{c}, 0 \mathrm{z}, 15 \mathrm{c}, 1 / \mathrm{lb} .40 \mathrm{c}$.

Netted Gem - This has become one of the most popular of small or basket melons. The fruit is oval, slightly ribbed, densely covered with coarse netting. Flesh thick, green, very sweet and highly flavored. Pkt. 5c, oz. 15c, 1/4 lb. 40c.

Banana-An entirely distinct variety, bearing long, slender banana-like fruit. Skin creamy white and entirely free from netting. Flesh deep salmon color, thick and good quality. Pkt. 5c, oz. $15 \mathrm{c}$.

\section{WATERMELON}

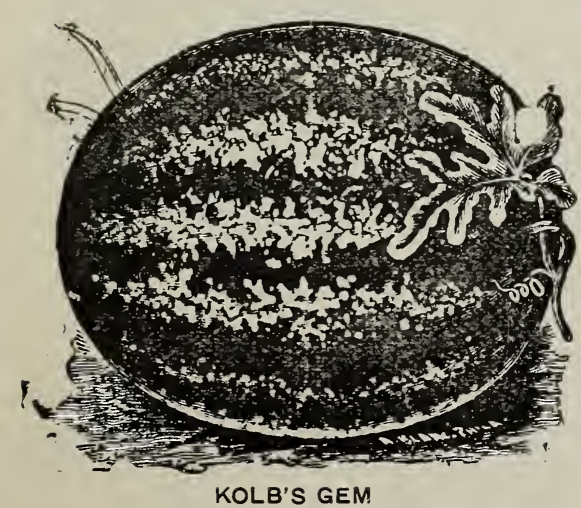

Cole's Early Watermelon_-Sweet and delicate in texture of flesh, which is a deep red color. The rind is thin, and the quality of the flesh is sustained clear to the rind. The melons are of medium size, nearly round in shape, rind green, striped with lighter shades. Pkt. $5 \mathrm{c}$, oz. $10 \mathrm{c}, 1 / 4$ lb. $15 \mathrm{c}, \mathrm{lb} .60 \mathrm{c}$.

Extra Early-Very desirable as the first Watermelon to ripen. Form oblong, weight from 15 to 16 lbs. Pkt. 5c, oz. 10c, $1 / 4$ lb. 20c, lb. 75 c.

Black Diamond_-It is enormously productive, reaching a mammoth size, with rich, dark green skin. It is one of the best "all-around" melons in existence, and for the family garden it is also without a peer. Pkt. $5 \mathrm{c}$, oz. $10 \mathrm{c}, 1 / 4$ lb. 20 c, lb. 60 c. 


\section{WATERMELON-CONTINUED}

Landreth's Boss-(Eighty days)--No Melon has ever been introduced which can be compared with the Boss. Everything going to make a perfect Melon; the edible portion of the flesh extending to within less than half an inch of the skin. Pkt. 5c, oz. 10c, 1/4 lb. 35c.

Icing-Unexcelled in all good qualities. Pkt. 5c, oz. 10c. $1 / 4$ lb. 15c, lb. 60c.

Dixie-The meat is fine, rich scarlet and of very superior quality. Pkt. 5c, oz. 10c. ${ }_{4}$ lb. 20c, lb. $75 \mathrm{c}$.

Arkansas Traveler-(Seventy-five days)-A large, long, weighty Melon; rind dark green with waving stripes of black; interior always solid: red, sweet, tender, crystaline Pkt. 5c, oz. 10c, 1/4 lb. 20c, 1b. 75 c.

Florida Favorite-A popular Melon, oblong, green with dark stripes. Pkt. 5c, oz. 10c. 1/4 lb. 20c, lb. 60c.

Gem-(Kolbs)-A solid shipper. Pkt. 5c, oz. 10c, 1/4 lb. 15c, lb. 50 .

Indiana Sweetheart-Good bearer and standing any amount of rough handling Pkt. 5c, oz. 10c, 1/4 lb. 20c, lb. 60c.

Kleckley Sweets-This splendid and most sweet Watermelon has certainly become very popular wherever it has been thoroughly tested. It is of superb, luscious flavor. While the skin is perhaps too thin to admit of the Melons being shipped very great distances to market, it is most desirable to plant for home use or local markets. The Melons themselves are very large, oblong in form, with dark green skin, thin rind. Oz. 10c, 1/4 lb. 25c.

Preserving Citron-Only for winter use. A round, light and dark striped Melon, meat greenish white, used for preserving only; seeds red and small. This should be more generally used. Pkt. 5c, oz. 10c, 1/4 lb. 20c, lb. 60c.

We make quality a first consideration. No effort is spared to make all our seeds the purest and most reliable.

\section{ONIONS}

\section{ONE OUNCE WILL SOW ABOUT IOO FEET OF ROW. FOUR POUNDS WILL SOW ONE ACRE}

\footnotetext{
Culture-Sow as early in the spring as practicable in rich, light soil, in drills atout fifteen inches apart, and
} when the plants are up thin to three or four inches.

There is no vegetatable where the quality of the seed exerts a greater influence upon the crop than in Onions. Good Onion seed is of the utmost importance. Sowing seed to produce large onions is the cheapest, easiest and most satisfactory way. Large onions can easily be grown the first year from the seed by obtaining our seed.

Extra Early Red-Matures very early; of medium size, flat shape, deep red in color, very close grained, solid and heavy. This will often form bulbs in cold and mucky soils where other varieties fail. It is recommended particularly for the North and Northwest. Pkt. 5c, oz. $15 c, 1 / 4 \mathrm{lb} .40 \mathrm{c}, \mathrm{lb} . \$ 1.25$.

Yellow (ilobe Danvers-A very handsome globeshaped variety of large size, yellow skin, white flesh, mild, very firm and the best of keepers. Pkt. 5c, oz. 15c, $1 / 4$ lb. 50 c. lb. $\$ 1.50$.

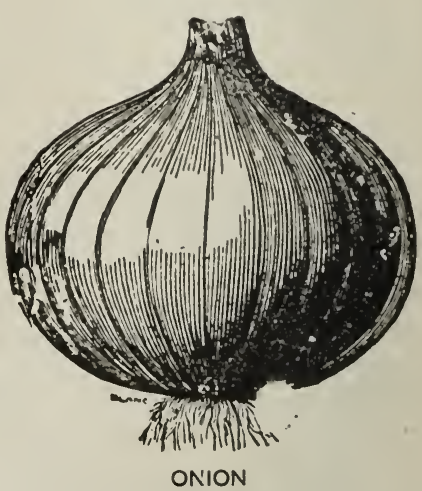

Extra Farly Long-Keeping Brown Australian-Planted with the Red Wethersfield, it proved to be nearly four weeks earlier and ripened off more uniformly. It will keep longer in good condition than any other Onion known. The color of the skin is a clear amber brown. Pkt. 5c, oz. 15c, 1/4 lb. 40c. 


\section{ONIONS-CONTINUED}

Large Red Wethersfield-Grow to a large size; fine form, skin deep red, fine grained and very productive; an excellent keeper. Our seed of this variety is extra select and cannot be excelled. Our price is low, but should you want five pounds or more, ask for special rates. Pkt. 5c, oz. $15 \mathrm{c}, 1 / 4 \mathrm{lb} .35 \mathrm{c}, \mathrm{lb} . \$ 1.30$.

Southport Red Globe-Matures quite early (none of the globe-shaped onions are as early as the flat varieties;) grows to a large size, skin deep red, flesh fine grained; mild and tender. Pkt. 5c, oz. $15 \mathrm{c}, 1 / 4$ lo. $40 \mathrm{c}, \mathrm{lb}$. $\$ 1.40$.

Southport White Globe-A showy, large white variety. Pkt. 5c, oz. 20c, lb. \$2.25.

Mammoth Prizetaker-Admittedly the largest of all varieties, having been grown to the enormous weight of over three pounds. Of a clear, bright straw color and uniform perfect globe-shape. Produces enormous crops and they bring an extra price. Keep wonderfully well and present the handsomest possible appearance in the market, while the pure white flesh is fine grained. Pkt. 5c, oz. $15 \mathrm{c}, 1 / 4 \mathrm{lb} .40 \mathrm{c}, \mathrm{lb} . \$ 1.50$.

Giant White Garganus-Also known as Silver King. Pkt. 5c, oz. 15c, 1/4 lb. 50c, lb. $\$ 1.75$.

Italian Queen-An extra early small silver skin onion. Pkt. 5c, oz. 15c, 1/4 lb. 40c, lb. $\$ 1.50$

Silver Skin or Portugal-Best white Onions for sets. Oz. 20c, lb. $\$ 2.00$.

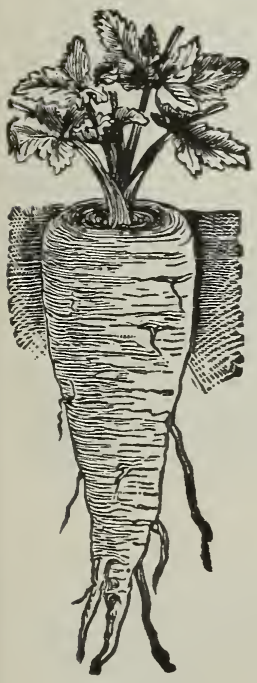

PARSNIP

\section{ORKA}

\section{TWELVE OUNCES OF SEED TO ONE HUNDRED YARDS OF ROW}

Culture-Plant the seed when the apple is in bloom, in drills three feet apart and eight or ten inches between the plants. The seeds are liable to rot in the ground and should be put in thickly. Very rich ground is demanded by this vegetable. It is necessary to make an earlier and later sowing to secure an uninterrupted supply throughout the season.

White Velvet-Tender, white pods. Pkt. 5c, oz. $10 \mathrm{c}$.

\section{PARSNIP \\ THREE OUNCES OF SEED TO FIFTY YARDS OF ROW, EIGHT POUNDS TO THE ACRE}

Culture-When the apple is in blossom, sow in shallow drills in good ground, deeply dug, cover the seed lightly. When the plants are up two or three inches, thin them to stand four inches.

Bloomsdale-The Bloomsdale is the best bred and handsomest Parsnip to be found. It is half long, wedge-shaped; hollow crowned and very broad at the shoulders, easily taken out of the ground, and producing more tons to the acre than the longer and more slim varieties. Pkt. 5c. oz. 10c, 1/4 lb. 15c, lb. 40c.

\section{PARSLEY \\ TWO OUNCES OF SEED TO ONE HUNDRED YARDS OF ROW}

Calture-Sow in early spring in rows twelve inches apart. Thin out the plants to four inches. To preserve in winter transplant in cold frames or light cellar.

Plain or Single-Pkt. $5 \mathrm{c}$, oz. $10 \mathrm{c}, 1 / 4 \mathrm{lb}$. 15c, lb. 50c.

Fine Curled or Double-Pkt. 5c, oz. 10c, $1 / 4$ lb. $15 \mathrm{c}, \mathrm{lb} .50 \mathrm{c}$.

Moss Curled-Pkt. 5c, oz. 10c, 1/4 lb. 15c. ib. $60 \mathrm{c}$

Hamburg, Turnip Rooted - Fleshy roots; used in soups and stews. Oz. 10c. $1 / 4$ lb. 20 c, lb. 50 c.

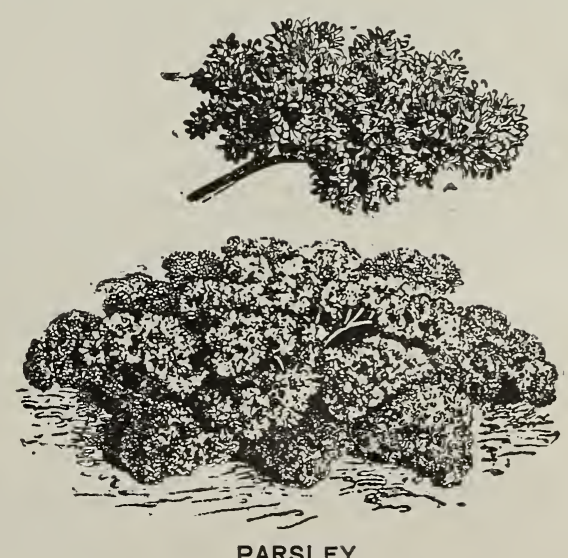

PARSLEY 


\section{PEAS}

\section{ONE QUART WILL PLANT ONE HUNDRED FEET OF DRILL THREE BUSHELS PER ACRE}

Culture-For the first early crop, sow as early as the ground can be worked, and at intervals of two weeks for succession. Sow in single or double rows, two inches deep and from three to four feet arart, according to the height and variety and strength of soil, supporting tall varieties with brush. Plant early varieties in August anc you will get a profitable crop by fall.

Landreths Extra Early Peas-The earliest of all very early peas. It is very profitable for the gardner, ripens uniformly, so that all the pods may be picked within seven weeks from the time of planting, and that at one picking. No brush or other support is required, as they seldom, under any circumstances, grow to exceed twenty inches in height. Pkt. 5c, pt. 20c. qt. 35c.

Alaska-A variety of remarkable earliness and hardiness. It is a good yielder and produces pods of good size and dark green color, which are well filled with round, smooth peas of splendid flavor. Height two feet. The color of the dried pea is green. It ripens very evenly, so that one pickıng will nearly clean off the crop. Pkt. 5c. pt. 20c, qt. 35c.

First and Best-Pods are good size and well filled with round, smooth peas of excellent flavor. Extremely early, productive. and ripen all at the same time. Pkt. 5c, pt. 20c, qt. 35c.

American Wonder-Vine six to eight inches high, and very prolific in pods of striking form and size. In maturity it is among the first earliest. Pkt. 5c, pt. 20 c, qt. 35 c.

Nott's Excelsior-An improvement on American Wonder, a shade earlier and large podded. Vine almost identical. Pkt. 5c. pt. 20c, qt. 35c.

McLean's Little Gem-An admirable second early, maturing for table fifty four days from germination. Pkt. 5c, pt. 20c, qt. $35 \mathrm{c}$.

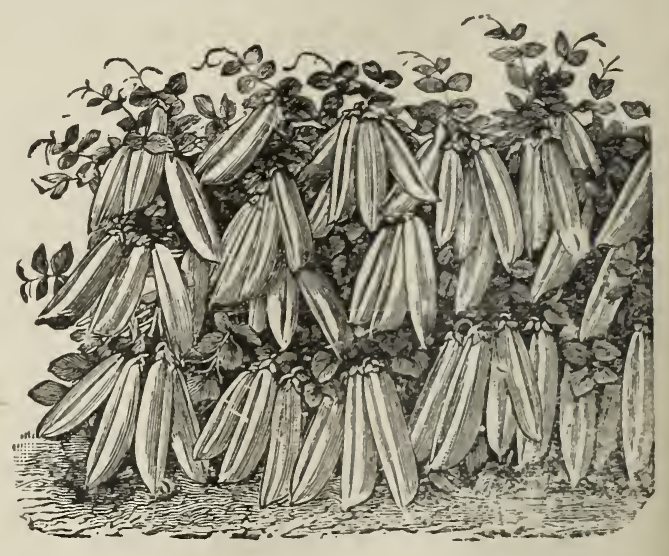

PEAS

Prosperity, or Gradus-This remarkable Pea is not only large and of the best quality. but is nearly or quite as early as the small, round, extra early sort. Gradus is a wrinkled pea, with a vine growing about thirty inches high. The pods are of a bright green color. and measure four inches or more in length, being as large as a Telephone, and equally as well filled with luscious peas, eight to ten or more in a pod. Pkt. $5 \mathrm{c}$, pt. $25 \mathrm{c}$, qt. $50 \mathrm{c}$.

Everbearing-Somewhat similar to Abundance. Pkt. 5c, pt. 20c, qt. 35c.

Champion of England-One of the best. Delicious flavor; profuse bearer of large pods, well filled with large green wrinkled peas; four feet. Pkt. 5c, pt. 20c, qt. 35c.

Main-Crop Long Island Marrowfat-Used profitably by market gardeners, being productive, showy in the basket, the pods having somewhat the appearance of Telephones. but are earlier by four or five days, being ready to pick for market in sixty days. Pkt. 5c, pt. $20 \mathrm{c}$, qt. $35 \mathrm{c}$.

Irish Large White Marrowfat-Pkt. 5c, pt. 20c, qt. 35 c.

Peruvian Black=eyed Marrowfat-Plant on thin soil. Pkt. $5 \mathrm{c}$, pt. 20c, qt. $35 \mathrm{c}$.

Open orders always filled at lowest prices. If you do not receive our Price Lists regularly, write for them. 


\section{PEPPER}

ONE OUNCE OF SEED TO ONE HUNDRED YARDS OF ROW

Culture-Start the plants under glass in the early snring, or outside when the apple is in bloom, against the shelter of a board fence or garden wall Transplant after corn-plarting time; setting in rows at three feet and two feet in the row.

Small Chili Réd-_.Fruit red. Very hot. Pkt. 5c, oz. 25c.

Very Small Cayenne_-Very superior to the old Cayenne, bearing fruit all over the plant. Fruit one inch in length and very hot. Pkt. $5 \mathrm{c}$, oz. 30c.

Cayenne-Fruit three inches in length. Pkt. 5c, oz. 25c. oz. $25 \mathrm{c}$

Golden Bell Similar in form to Sweet Spanish. Pkt. 5c,

Large Sweet Spanish_Generally used for pickles. Pkt. 5c. oz. $25 \mathrm{c}$.

Bull Nose_Larger fruit than the S not. Pkt. $5 \mathrm{c}$, oz. $25 \mathrm{c}$.

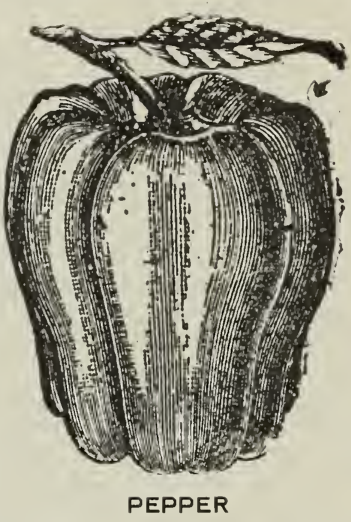

Celestial -From one to two inches long. Fruit green from the blossom, turning alternately to lemon, golden and scarlet. Pkt. 5c, oz. 25c.

Magnum Dulce See Novelties.

\section{PUMPKIN}

TWO QUARTS TO THE ACRE HILLS EIGHT BY EIGHT FEET

Yellow Cashaw_Large, yellow-crook neck, weigh as high as 60 to 100 pounds. Not the winter crook-neck squash, four times as big and ten times as desirable. Pkt. $5 \mathrm{c}, \mathrm{oz} .10 \mathrm{c}$, $1 / 4$ lb. $20 \mathrm{c}, \mathrm{lb} .75 \mathrm{c}$.

Cheese-Shape flat, like a rheese box. Pkt. 5c, oz. 10c, 1/7 lb. 15c, lb. 40c.

Common Field-Pkt. 5c, lb. 30c.

Monster Yellow_Growing to the weight of 100 to 200 pounds. Pkt. $5 \mathrm{c}$, oz. 10c, lb. $\$ 1.00$.

\section{RHUBARB}

\section{FOUR OUNCES OF SEED WILL SOW ONE HUNDRED YARDS TEN POUNDS TO THE ACRE}

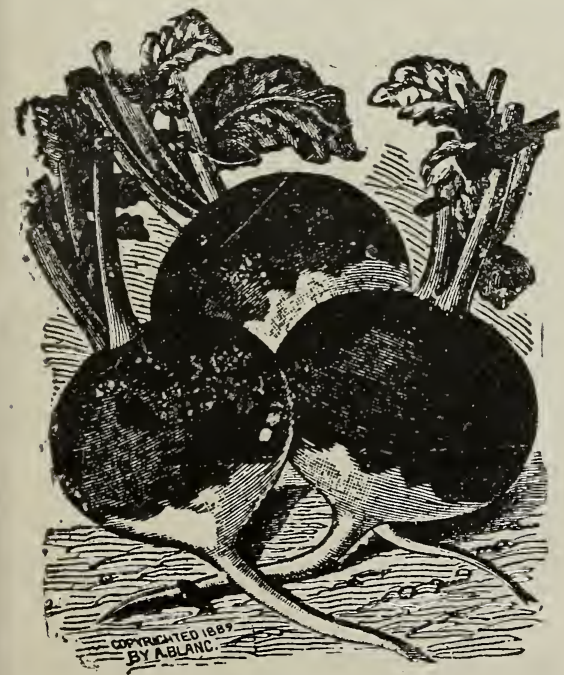

RADISH

Culture-Sow the seed when the cherry is in bloom, in rows at one foot and thin the plants to ten inches. Mark the ground $3 \times 4$ or $4 \times 4$ feet, preparing a rich bed for each plant. Success can only be obtained on well manured grcund. The fertilizing cannot be over done. Oz. 20c.

We supply roots as well as the seed. They continue vigorous many years. Price $75 \mathrm{c}$ per dozen; 10c each. They are shipped only by express, being too heavy for the mails.

\section{RADISH}

\section{TWO OUNCES OF SEED WILL PLANT ONE HUNDRED FEET OF ROW}

Culture-Sow early in the spring in rows a foot apart, and every week or ten days for a succession up to the middle of June, after which they are but little used, unless a cool northern spot can be secured. Sow in early fall for late crops and winter use.

Earliest Scarlet Turnip_-Among quickest maturing of the Red Turnip Radishes. Small root and small top. An excellent forcing variety. Pkt. $5 \mathrm{c}$, oz. $10 \mathrm{c}, 1 / 4 \mathrm{lb} .20 \mathrm{c}$.

White Tipped Early Scarlet TurnipScarlet bulb with white blossom, very showy and delicate; a choice variety. Pkt. $5 \mathrm{c}$. oz. $10 \mathrm{c}$. $1 / 4$ lb. $20 \mathrm{c}$. 


\section{RADISH-CONTINUED}

French Breakfast-Olive shaped, the upper part of bulb scarlet, the bottom tipped with white. Pkt. 5c, oz. 10c, 1/4 lb. 20c.

Early Scarlet, Olive Shaped-Clear, deep scarlet; flesh tender and excellent; very early; fine for forcing and general crop. Pkt. 5c, oz. 10c, 1/4 lb. $20 \mathrm{c}$.

Market Gardeners' Early Long Scarlet-An admirable long variety for forcing. fully ten days earlier than the long scarlet, and very superior to it for that reason. Twentythree days to maturity, Pkt. 5c, oz. 10c, 1/4 lb. $20 \mathrm{c}$.

White Ladyfinger-Twenty-three days to maturity. A large white, crisp variety about half as long as the Long Scarlet and similar in shape. A very desirable sort, decidedly the best of its kind ever introduced. An admirable market sort of nutty flavor. Pkt. 5c. oz. $10 \mathrm{c}, 1 / 4 \mathrm{lb} .20 \mathrm{c}$.

Early Long White Vienna-- An early long white variety of good quality. Pkt. 5c, oz. 10c, 1/4 lb. 20c.

White Strasburg - Long, white. early to develop, and keeping in edible condition for five or six weeks. Pkt. 5c. oz. $10 \mathrm{c}, 1 / 4 \mathrm{lb} .20 \mathrm{c}$.

Long White Icicle Half long, slightly stump rooted; matures quickly, suitable for forcing. Pkt. 5c, oz, 10c, $1 / 4 \mathrm{lb} .20 \mathrm{c}$.

Golden Globe-Shape globular, color amber, flavor mild, keeping long in eating condition. Pkt. 5c, oz. $10 \mathrm{c}, 1 / 4 \mathrm{lb}$. $20 \mathrm{c}$.

Earliest White Turnip, Short Top -Of quick growth, roots round, pure white, leaves short, flavor excellent, fine for forcing and open ground. Pkt. 5c. oz. 10 c, $1 / 4$ lb. 20 c.

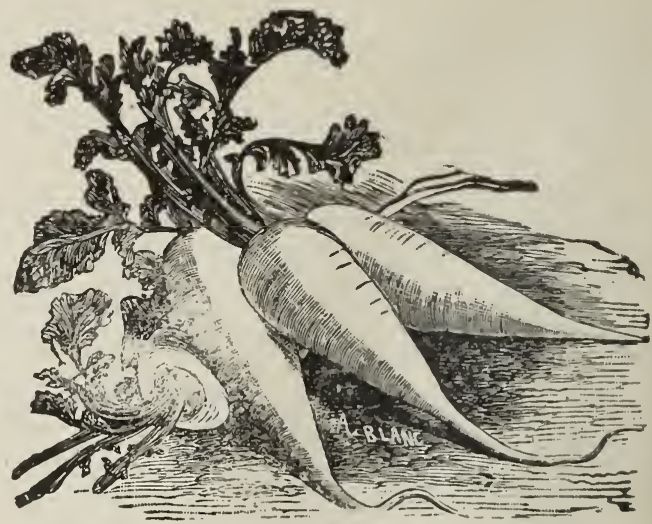

RADISH

Round Black Spanish-A winter Radish, cultivated in autum, and keeping like a potato for months after harvesting. Pkt. 5c, oz. 10c, 1/4 lb. $20 \mathrm{c}$.

Scarlet China Winter-Root a half-long stump two or three inches, tipped with white keeps perfectly. Pkt. 5c, oz. 10c, 1/4 lb. 20c.

White Wonder-See Novelties.

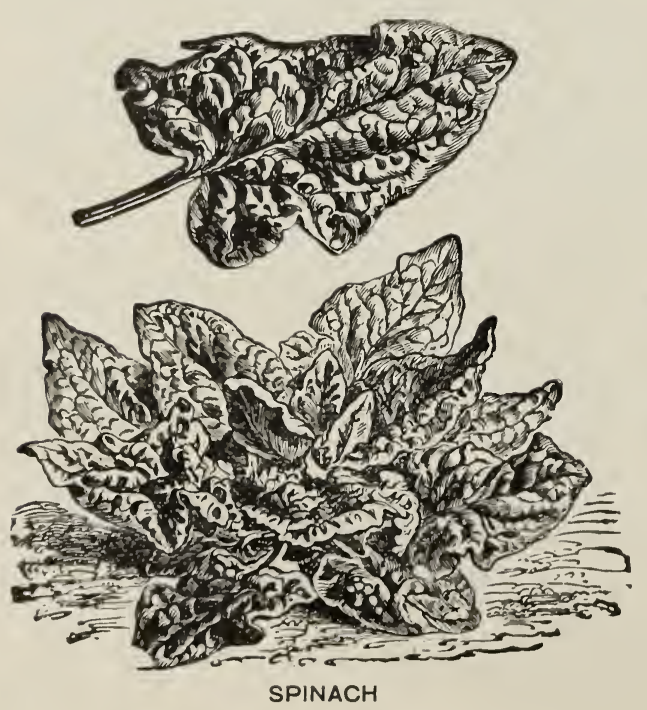

\section{SPINACH}

\section{SIX OUNCES OF SEED TO ONE HUNDRED YARDS OF ROW. THIRTY POUNDS TO THE ACRE}

Culture-Sow when the peach is in bloom, in drills at one, two or three feet, or broadcast, which is the usual system. If sown in drills, six ounces of seed will sow one hundred yards of row, or a square equal to ten by ten yards, if sown broadcast.

Bloomsdale Spinach-Curled quality. giving the leaves an elasticity while at the same time giving the crop large measuring qualities, many more barrels of the Bloomsdale Spinich being cut to the acre than any other variety. Pkt. 5c, oz. 10c, lb. 30c. 4 lbs. $\$ 1.00,10$ lbs. $\$ 2.00$.

Ever Ready-So named because it arrives at cuttıng size as soon as any other sort, and continues in cutting condition three weeks longer than the latest. Pkt. 5c. oz. $10 \mathrm{c}, 1 \mathrm{~b} .30 \mathrm{c}$.

Long Standing Prickly SeededSame habit as the round seeded, seed prickly. Pkt. 5c, oz. 10c, lb. 30c. 


\section{SQUASH}

\section{THREE OUNCES OF SEED WILL SOW ONE HUNDRED YARDS. THREE POUNDS TO THE ACRE}

Culture-This seed may be planted first when the apple is in bloom and for several weeks subsequently.

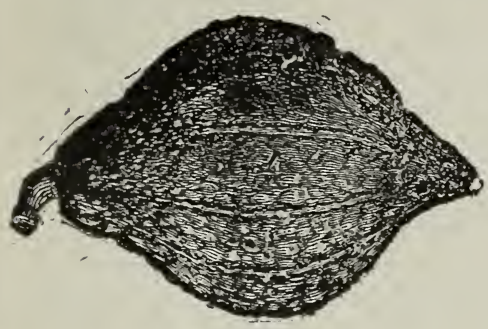

SQUASH

Extra Early Bush-(Forty days)-Maturing fruit for table use within forty days from germination. Pkt. 5c, oz. 10c, $1 / 4$ lb. $25 \mathrm{c}$.

Golden Summer Crookneck-(Forty days)Best of the Summer Squashes, golden in color. Pkt. 5c. oz. $10 \mathrm{c}, 1 / 4 \mathrm{lb} .25 \mathrm{c}$.

Hubbard - This old variety has for years stood the test of all rivals; hard green shell; flesh bright orange yellow, fine grained, very dry, sweet and of a rich flavor. Pkt. 5c, oz. $10 \mathrm{c}, 1 / 4 \mathrm{lb} .25 \mathrm{c}$.

Warty Hubbard-The wartiness indicates a very hard shell, which is one of the best features of a long keeping Squash. Pkt. 5c, oz. 10c, 1/4 lb. $25 \mathrm{c}$.

\section{SALSIFY, OR OYSTER PLANT \\ FOUR OUNCES OF SEED WILL SOW ONE HUNDRED YARDS}

Culture-This plant produces an edible root, long and slim, white fleshed and smooth, white skin. Sow when the cherry is in bloom, in drills, in deeply dug and well manured ground; the drills should be eighteen inches apart. When the plants are up a few inches, weed and thin them so as to stand four or five inches from each other. Preserve in pits, same as Carrots and Beets. Cultivate in all respects as directed for carrots.

Sandwich Island-Producing smooth, large and vigorous roots. Pkt. 5c, oz. 15c, 1. lb. $40 \mathrm{c}$.

\section{TABLE TURNIP}

\section{THREE OUNCES OF SEED WILL SOW ONE HUNDRED YARDS. FOUR POUNDS TO THE ACRE} in July.

Culture-For early Turnips, sow as soon as the ground can be worked in the spring. For winter use sow

Extra Early Purple=Top Milan-The bulb is very flat, of medium size, quite smooth, with a bright purple top, Pkt. 5c, oz. $10 \mathrm{c}, 1 / 4 \mathrm{lb}$. 20c, lb, 60c,

Early Flat Red or Purple=Top-Pkt. 5c, oz. 10c, 1/4. lb. $20 \mathrm{c}, 1 \mathrm{~b} .60 \mathrm{c}$,

Early Flat Dutch-Pkt. 5c, oz. 10c, lb. 50c.

Large Early Red=Top Globe-A very much heavier producer than any of the preceeding. We confidently recommend it as an acquisition. Pkt. 5c, oz, 10c, 1/4 lb. 20c, lb. $60 \mathrm{c}$.

Golden Ball-A small yellow Turnip of second size, early and a good keeper. Pkt. 5c, oz. 10c, $1 / 4$ lb. $15 \mathrm{c}, 1 \mathrm{~b}, 50 \mathrm{c}$.

Amber Globe, Green Crowned--Is a vigorous, free grower, valuable for both table and cattle feeding. Productive and a good keeper. Pkt. 5c, oz. 10c, 1/4 lb. $15 \mathrm{c}, 1 \mathrm{~b} .50 \mathrm{c}$.

Yellow Aberdeen, or Scotch Yellow-This is a highly approved Cattle Turnip, attaining a large size. Pkt. 5c, oz. $10 \mathrm{c}, 1 / 4 \mathrm{lb} .15 \mathrm{c}, 1 \mathrm{~b} .50 \mathrm{c}$.

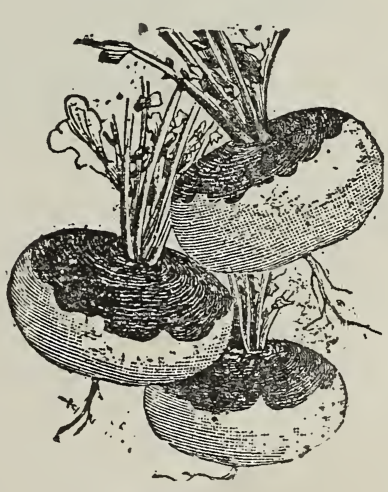

TURNIP

Bloomsdale Swede, or Ruta Baga-The Bloomsdale is delicate in texture, purple crowned, golden skinned, almost perfectly globular in form, and earlier to mature than any other known form of Ruta Baga. Pkt. 5c, oz. 10c. 1/4 lb. 20c, lb. 60c. 


\section{TOMATO}

ONE OUNCE WILL PRODUCE ABOUT TWO THOUSAND PLANTS

Culture-Sow in the hot bed in early spring. Transplant into the open ground as soon as all danger of frost is past. Some support should be provided for the vines to keep the fruit from touching the ground.

\section{SPARK'S EARLIANA}

The Earliest, Large, Smooth, Red Tomato. - This is not only remarkable for its earliness, but for its very large size, handsome shape and bright red color. Its solidity and fine quality are quite equal to the best medium and late sorts. Pkt. 5c, oz. 30c.

\section{NEW GLOBE TOMATO}

A good general cropper, and one of the very best for first early crop; on stakes or trellis. An entirely distinct and fixed new sort. Every grower of Livingston's New Globe, whether he grows for private or market purposes, will be pleased with the beautifi: and attractive globe-shaped fruit. Pkt. 5c, oz. 30c.

\section{DWARF STONE TOMATO}

The strong, upright growth allows very close planting, at least a half closer each way than the distance required by the ordinary vining varieties. In small gardens the plants may be set $18 \times 24$ inches apart each way, and yet produce an abundant crop. Pkt. 5c, oz. 30c. $1 / 4$ lb. 75 c.

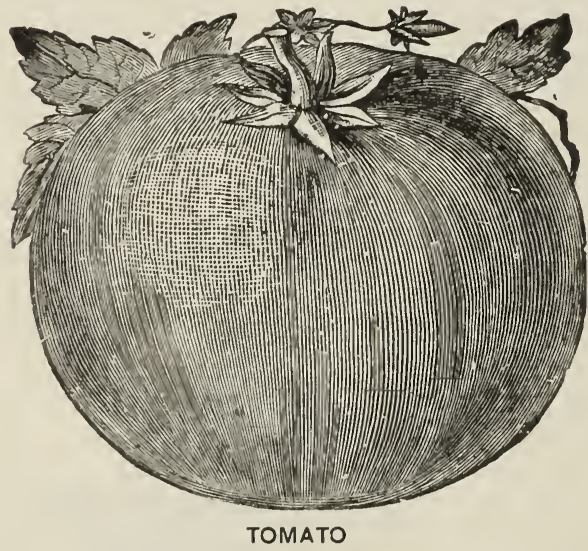

Dwarf Champion - Fruit borne in showy clusters, quite large, nearly round, solid. red color with purple tint. Pkt. $5 \mathrm{c}$, oz. $25 \mathrm{c}$. $1 / 4$ lb. $75 \mathrm{c}$.

Early Acme-Very productive; fruit of medium size, perfect form, round, slightly depressed at the ends, and very smooth; a giossy red with purple tinge. Pkt. 5c, oz.25c, $1 / 4 \mathrm{lb} .60 \mathrm{c}$.

Livingston's Stone--Its solidity and carrying qualities are remarkable. Its color is a desirable red; in shape perfectly smooth and thicker from stem to blossom than most varieties. Pkt. $5 \mathrm{c}$, oz. $25 \mathrm{c}, 1 / 4 \mathrm{lb} .60 \mathrm{c}$.

Perfection - Invariably smooth and of a handsome blood-red color. All who have tried it pronounce it of the highest quality. Pkt. 5c, oz. 25c. $1 / 4$ lb. 60c.

Livingston's Beauty Large size, always smooth, perfect in shape and excellent in quality. The color is very glossy crimson. Pkt. 5c, oz. $25 \mathrm{c}, 1 / 4 \mathrm{lb} .60 \mathrm{c}$.

Ponderosa The fruit ripens quite early and keeps on coming until very late. Of immense size, solid. almost seedless. The fruits are somewhat scattered on the vine. Pkt. 5c. oz. $30 \mathrm{c}, 1 / 4 \mathrm{lb}$. S1.00.

Peach Tomatoes It is desirable for eating from the hand. The skin is thin and peals off like a peach. Oz. 35c.

Golden Queen Pkt. 5c. oz. 25c.

Pear Shaped Yellow Pkt. 5c, oz. 30c.

Grape, Cherry or Currant Fruit borne in clusters; very desirable for pickles or preserves. Ornamental. Pkt. 5c, oz. 30c.

Husk, or Strawberry ...This delicate husk-enveloped Tomato is unequalled for making preserves and pies. They are handsome in color. Pkt. $5 \mathrm{c}, \mathrm{oz} .50 \mathrm{c}$. 


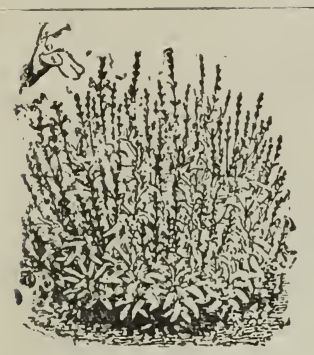

SAGE

\section{HERBS}

For flavorıng soups, meats, etc., a few pot and sweet herbs are necessary for every garden. If they are to be used during the winter, the stocks should be cut on a dry day, when not quite in full bloom. They should then be dried quickly in the shade, and when dry be packed closely in boxes, with the air entirely excluded.

Sage-Leaves and tops are used for seasoning and stuffing. Pkt. $5 \mathrm{c}$, oz. $15 \mathrm{c}$.

Summer Savory-The leaves and young shoots are used for flavoring, especially for boiled string beans. Pkt. 5c, oz. $15 \mathrm{c}$.

Anise-Use for garnishing, seasoning and for cordials. Pkt. $5 \mathrm{c}$, oz. $10 \mathrm{c}$.

Thyme-Used for seasoning. Pkt. 5c, oz. 25c.

Caraway-Seeds are used for flavoring bread, pastry, meats, etc. Pkt. 5c, oz. 10c.

Dill-Leaves are used in pickles, and for flavoring soups and sauces. Pkt. $5 \mathrm{c}, 0 \mathrm{z}, 10 \mathrm{c}$.

Lavender - The leaves are sometimes used for seasoning, but the plant is chiefly grown for its flowers which are used in the manufacture of perfumery. Pkt. $5 \mathrm{c}$, oz. $15 \mathrm{c}$.

Majoram, Sweet-The leaves and the ends of the shoots are used for flavoring, both in summer, and also dried for winter use. Pkt. 5c. oz. $15 \mathrm{c}$.

Catnip-Pkt. 5c.

Martynia-Pkt. 5c.

Mint Root-Each 10c, doz. $\$ 1.00$.

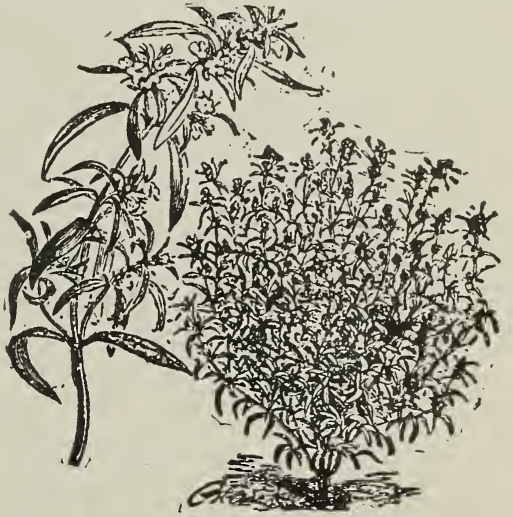

SUMMER SAVORY

\section{VEGETABLE PLANTS}

Cabbage, Early-Ready by April 20th. Extra. Early Wakefield, All-Seasons and Early All-Head. Doz. 10c; $10055 \mathrm{c} ; 1000 \$ 4.25$.

Cauliflower, Early-Ready by April 20th. Snowball and Extra Early Erfurt, Doz. $15 \mathrm{c} ; 100 \$ 1.00 ; 1000 \$ 6.00$.

Celery, Early-Ready in June. White Plume, Golden Self-Blanching, Doz. 10c; 10050 c; $1000 \$ 4.00$.

Egg Plant-Ready about May 15th. New York Improved Purple. Doz. 20c; 50 60c; $100 \$ 1.00$.

Pepper-Ready about May 15th. Bell or Bull Nose, Sweet Mountain, Extra Ruby, King and Cayenne. Doz. 20c; $100 \$ 1.00$.

Sweet Potato Ready about May 15th. Yellow Jersey. 100 35c; $1000 \$ 2.50$.

Tomato Ready about May 15th. Acme, New Stone, Dwarf Champion, Ponderosa. Doz. 10c; 100 75c; $1000 \$ 7.00$.

Chives $10 \mathrm{c}$ bunch.

\section{ONION SETS}

\section{SUBJECT TO FLUCTUATIONS}

These are the product of seed, and are used for "green" onions or to produce large onions. which they do much quicker than can be grown from seed.

White Bottoms -Our sets of this are very choice, small, dry and unsprouted. Bu. (32 lbs.) \$3.00; pk. 90c; qt. 20c.

Yellow Bottoms - Fine dry sets, medium in size and unsprouted. Pk. 90c; qt. 15c.

Red Bottoms -Bright, deep red in color, even and dry. Bu. \$2.00; pk. 90c; qt. 15.

\section{SEED SWEET POTATOES}

Yellow Jersey -Prices on application. 


\section{SELECTED FARM SEEDS}

SUBJECT TO MARKET CHANGES

Fully appreciating the great importance of good field crops, we have given particular attention to this department of our business, and have made the selection of Farm Seeds a specialty, exercising great care to secure the best varieties, thoroughly cleaned and of the finest possible quality.

\section{CORN}

Pride of the North - This variety has been grown and improved in the extreme northern part of Iowa. Pk. 60c, bu. \$1.75.

Extra Early Dent-Ripening in ninety days. The ears are small, but is a great yielder Pk. 60c, bu. $\$ 1.75$.

lowa Gold MIne-Pk. 60c, bu. \$1.75.

Improved White Dent-- Pk. 60c, bu. \$1.75.

Legal Tender-Is a heavy Corn, rich in fattening substance, and will sell for the highest price upon any market. Pk. 60c, bu. \$1.75.

White Pearl, Silver Mine, Leaming-Pk. 60c, bu. $\$ 1.75$.

\section{POP CORN}

Queen's Golden- Pkt. 10c. pt. 15c, qt. 25c. White Rice-Pkt. 10c. pt. 15c, qt. 25c

SUGAR CANE

PRICES ON APPLICATION

MILLETS

German Millet Golden Millet Rye

PRICES ON APPLICATION

DWARF ESSEX RAPE

TRUE BIENNIAL VARIETY

Twenty-five pounds or over, $8 \mathrm{c}$ per pound. Send for special price.

\section{CHOICE SEED POTATOES}

\section{PRICES SUBJECT TO MARKET CHANGES}

A Change of Seed is Absolutely Necessary to insure large crops of Potatoes. The difference in yield will many times pay the cost of new seed. At the price we offer Potatoes no one can afford to plant his own seed, if it has been grown in the same soil two years or more. Some of our patrons buy seed of us each year, rather than to plant that of their own growing, and the universal success with which our patrons have met by planting them assures us of the fact that our Seed Potatoes are unsurpassed.

Extra Early Ohio Potatoes are selected with utmost care, and the result is grand. such as to delight everyone who knows and appreciates a good Potato. Pk. 50c, bu. \$1.75.

Early Six Weeks -Potatoes are marketable size in six weeks after planting. It is certainly a very early and a very good Potato. Pk. 50c, bu. \$1.75.

Clark's No. 1-Handsome, uniformly large; an enormous yielder. Pk. 50c. bu. \$1.25.

Rurual New Yorker-Intermediate in ripening and unsurpassed in table quality. $\mathrm{Pk}$ 50c. bu. $\$ 1.75$.

Bliss Triumph--One of the earliest Potatoes: chunky in shape, medium size, pink skin. An exceedingly fine sort. Pk. 50c. bu. \$1.75. 


\section{GRASS AND CLOVER SEEDS}

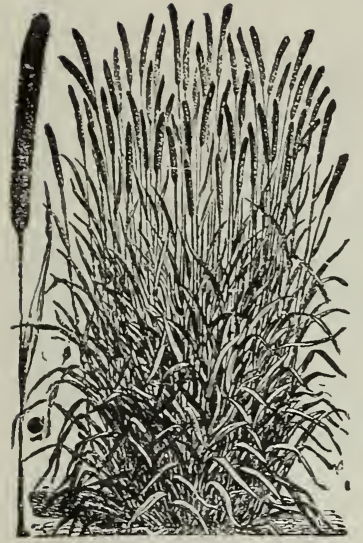

TIMOTHY

Customers understand that prices on Grass and Clover Seeds are changing almost daily, and that we can only give prices subject to market fluctuations. Those wanting seed in larger quantity than here quoted should write for special prices.

Blue Grass-Sow in fall and spring at the rate of two or three bushels per acre. Fancy, clean seed. (Bu. 14 lbs.) Lb. 4.0 c, bu. $\$ 4.00$.

Orchard Seed-Furnishes an abundance of pasture during the entire season. One and a half to two bushels per acre. (Bu. 14 lbs.) Lb. 25c.

Red Top Grass - Thrives best in low land, and produces a very firm sod. Lb. $25 \mathrm{c}$.

Timothy - Write us for latest prices.

English Rye Grass, Perennial Ryé-(Bu. 24 lbs.) Lb. $25 \mathrm{c}$.

Brome Grass-The yield of hay varies from one to four and a half tons per acre, according to climatic conditions and fertility of soll. (Bu. 14 lbs.) Lb. $15 \mathrm{c}$.

\section{CLOVERS}

Mammoth Clover-Being a rank grower it is largely used for plowing under as a fertilizer. Bu. \$12.00.

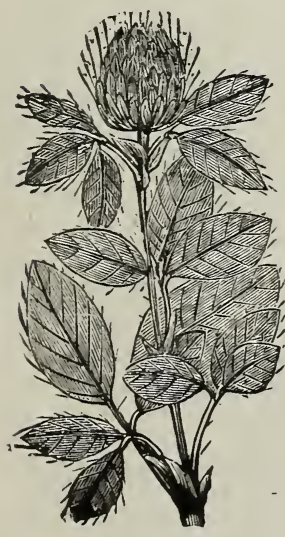

ALSIKE

\section{White Dutch-Lb. $40 \mathrm{c}$.}

Medium or Common RedThe most important and valuable of the clover family for agricultural purposes. Sow 15 pounds to the acre. (Bu. $60 \mathrm{lbs}$.) Bu. $\$ 9.00$ to $\$ 12.00$.

Alsike--On rich, moist soil it yields an enormous quantity of hay or pasturage, but its greatest value is for sowing with other clover and grasses, as it forms a thick bottom, has fibrous roots like White Clover. Esteemed highly by the bee keeper. Lb. 25 c.

Alfalfa-Very popular in many portions of the country. Lb. $25 \mathrm{c}$, bu. $\$ 10.00$ to $\$ 12.00$.

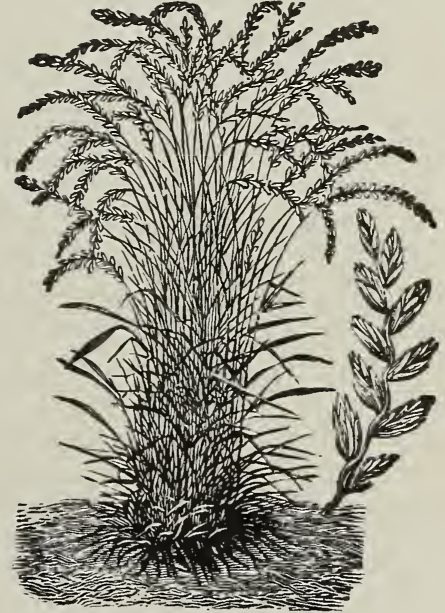

ORCHARD GRASS

\section{GRASS SEED MIXTURES FOR MEADOWS AND PASTURES}

It is a well ascertained fact that a thicker and more prolonged growth is produced by a mixture of many sorts of grasses than by only one or two. For every different kind and condition of soil there are grasses which are especially suitable. Some sorts do best on high ground and in dry weather. Others prefer plenty of moisture. Some mature so early, and others so late, that from the beginning of spring until winter sets in there is no time when one species or another is not at its best. $15 \mathrm{c}$ per lb. $25 \mathrm{lbs}$. to the acre. 


\section{LAWN SEED}

It will produce an even dense growth of permanent sward as early in the season as it is possible to do. This mixture contains no annual grasses for making quick show to the detriment of a good lawn, but only those of lasting value and hardiness. which when once established, need no reseeding for years. Our seed, which we know to be as pure as can be found anywhere, is of the best varieties. best suited for even and permanent growth; it is carefully cleaned. Lb. 35 c. 3 lbs. \$1.00.

\section{FOR SHADED LAWNS}

A selection of the fine grasses which thrive naturally under the shade of trees or buildings, or are suitable for light, sandy soil. This mixture was extensively used on the World's Fair grounds, where it gave splendid results. Lb. $35 \mathrm{c}, 3$ lbs. $\$ 1.00$.

\section{QUANTITIES TO USE}

One pound for 400 square feet......S .35

Five pounds for 2000 square feet.... 1.60

Ten pounds for 4000 square feet.... 3.00

Fifteen pounds for 6000 square feet. $\$ 4.30$

Twenty-five pounds for one-fourth acre 7.25

Fifty pounds for one-half acre...... 14.25

Kentucky Blue Grass-Many prefer this to a mixture of grasses, and the fact cannot be denied that a lawn of Blue Grass only is magnificent. It takes longer, however to get it established. Lb. 40c.

\section{White Clover- Extra choice seed. Lb. 40c.}

Red Top Grass - Fancy clean seed. Where an immediate effect for one season is desired there is none better than the Red Top Grass, as it comes up quickly and makes a beautiful lawn, but the grass is liable to winter-kili. Lb. 30c.

\section{LAWN FERTILIZER}

Lawn grass is a very voracious feeder and will not thrive and hold its beautiful dark green and velvety a ppearance unless it receives a sufficient supply of suitable food. Because so few appreciate this fact is the reason there are so many poor, rusty-looking lawns. Stable manure is unpleasant to handle. ill lookıng and decidedly odorous, and it is also full of waste material. It contains weed seeds which are obnoxious and it often takes years to eradicate the weeds. causing an unnecessary amount of labor. All these objections are obviated by the use of our Lawn Fertilizer. If the lawn is in fair condition it is only necessary to rake off the dead leaves and grass in the early spring and scatter broadcast over its surface. some of our Lawn Fertilizer with a little Lawn Seed over the thin spots, and the work is done.

Directions for Use - The first application should be made early in the spring, as soon as the frost is out of the ground, at the rate of twenty-five pounds of fertilizer to every 1000 square feet of lawn, evenly distributed. For seeding down a new lawn scatter double the amount, say fifty pounds of fertilizer, broadcast on every 1000 square feet and rake it in thoroughly before sowing the seed. Lb. $5 \mathrm{c}$, eight lbs. 35c, twenty-five lbs. 51.00 , fifty lbs. $\$ 1.75$, one hundred lbs. $\$ 2.75$. 


\section{FLOWERS}

Our constant aim is to secure the very best strain obtainable, both of home and foreign growth, and we spare no pains and expense with this object in view.

\section{ASTERS}

For profusion of flowers and richness of display the Asters are unrivaled, and constitute the principle adornments of our gardens during the autumn.

\section{QUEEN OF THE MARKET}

The earliest of all the Asters. Grows about nine inches high and very branching; the fine double flowers are produced freely on long stems, making it valuable for cutting. Pure White 10c, Blue10c, Crimson 10c, Mixed 5c.

\section{SEMPLE'S BRANCHING}

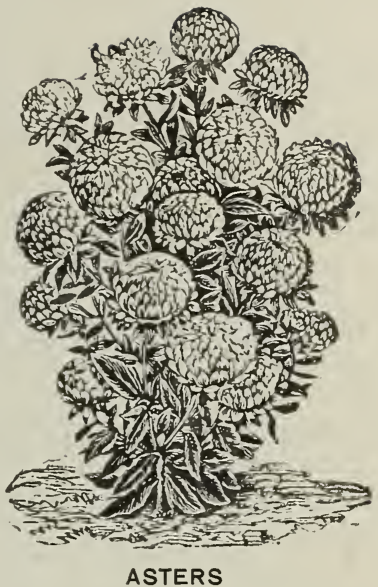

A beautiful class of Asters, useful for cut flowers. The flowers are very large, and double, borne on long, stiff stems, and the colors are clear and handsome. A favorite with florists. Pink 10c. White 10c, Dark Red 10c, Lavender 10c, Mixed, 1/8 oz. 25c, pkt 5c.

\section{PAEONY FLOWERED PERFECTION}

A magnificent globe-shaped. Seeds saved from the most perfect of this grand strain. $11 / 2$ feet. Snow White 10c, Pink 10c, Crimson 10c, Light Blue 10c, Dark Scarlet 10c, Mixed, many choice colors, $1 / 8$ oz. $25 \mathrm{c}$, pkt. $5 \mathrm{c}$.

To have a continuous bloom all season select one of each variety. Three for $10 \mathrm{c}$

\section{CHRYSANTHEMUM FLOWERED}

Mixed. Mauve. Red-White Edged. Rose. Violet-White Edged. White.

Produces the largest flowers of all the Asters; fine for border or pots. One ft. Pkt. 1.0c.

\section{VICTORIA}

A beautiful class. Flowers very large and perfectly double, of globular shape and beautifully imbricated. Plants grow in fine pyramidal form about eighteen inches high. All colors mixed, $1 / 8$ oz. $25 \mathrm{c}$, pkt. $5 \mathrm{c}$.

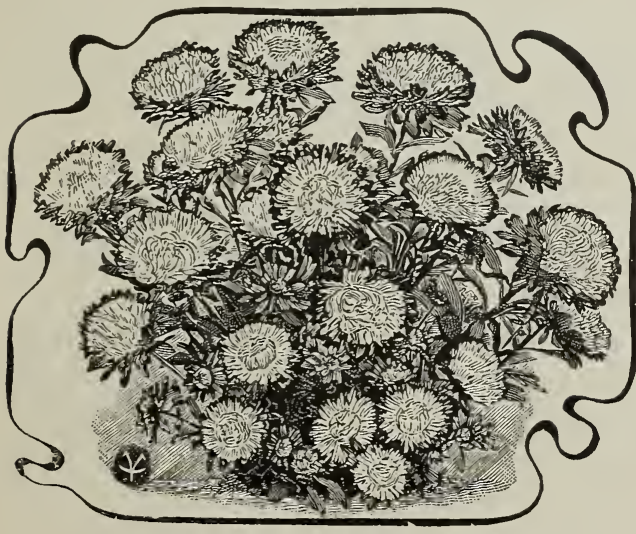

GLORIA OR BUTTONHOLE ASTER

\section{GIANT COMET}

This class is one of the handsomest of the tall growing sorts. The plants grow about eighteen inches high and bear in great abundance their immense flowers. These flowers, with their long, twisted petals, strikingly resemble Japanese Chrysanthemums. Snow While, of immense size, 10c, Striped 10c, Pink 10c, Mixed. $5 c$.

\section{VIOLET KING ASTER}

\section{A NEW AND DISTINCT VARIETY}

In shape and size the bloom is round, full and very large, many of the flowers measuring from four to five inches in diameter. Its color is soft violet lilac. Pkt. $10 \mathrm{c}$.

\section{GLORIA OR BUTTONHOLE ASTER}

The plants grow to a height of ten inches, are very branching and free blooming. As many as forty flowers have been counted on many plants. The flowers are about two and one-half inches in diameter and pure white with a brilliant scarlet margin. Pkt. 10c. 


\section{ALYSSUM--SWEET}

A very desirable, hardy annual, flowerIng from early spring until killed by the frost. Pkt. 5c, oz. 40c.

Little Gem - Three to four inches high. They soon become one mass of white, remaining in full bloom from spring to fall Pkt. 5c. 14 oz. $15 \mathrm{c}$.

\section{AMARANTHUS}

A most beautiful plant; height two feet; the leaves are long and narrow, the upper ones of the brightest glowing crimson. Pkt. 5c.

\section{ANTIRRHINUM}

The Snapdragon is an old favorite, with dark, glossy leaves and curiously shaped flowers. Mixed, all colors. Pkt. 5c.

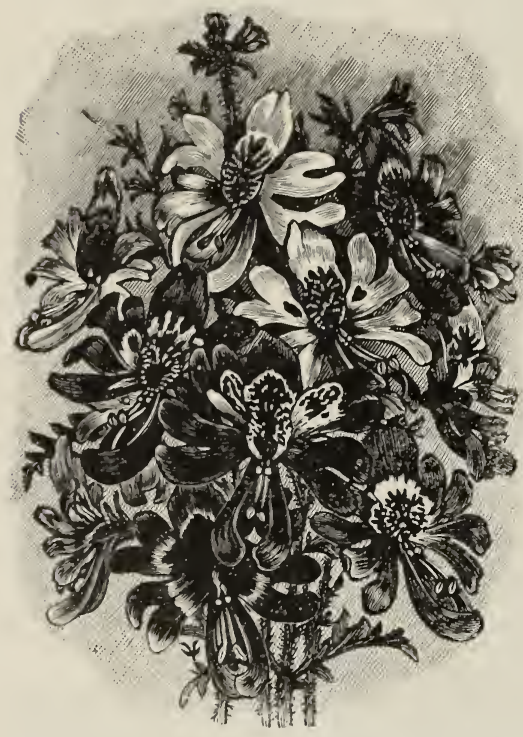

SCHIZANTHUS, OR BUTTERFLY FLOWER

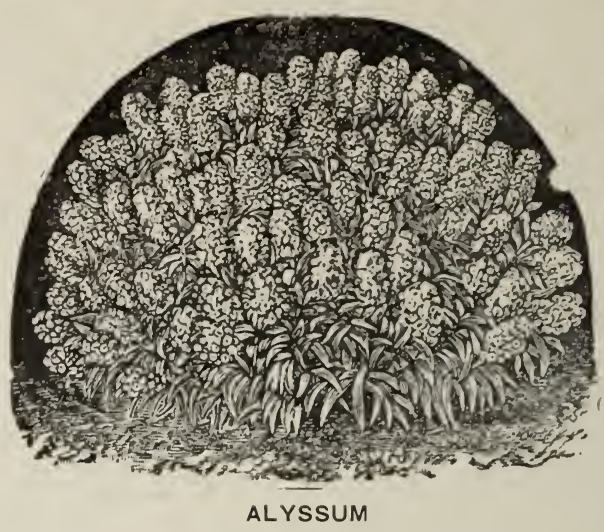

AGERATUM

Princess Pauline-Of dwarf compact habit, its peculiarity being that both colors, blue and white. are combined in the same flower. Pkt, 5c.

BUTTERFLY FLOWER--THE POOR MAN'S ORCHID

It grows well if sown in the open ground in March or April, where it is to bloom, but may also be sown in frames and transplanted later into the garden or pots, and if sown in August or September, several plants together in a pot. cultivated in a cool greenhouse or conservatory, they will make a splendid show in winter. Pkt. 10c.

\section{BALSAM}

Camilla, Flowered, Snow White-Pkt. 5c.

Solferino-Beautiful striped and spotted. Pkt. 5c Double Spotted-In splendid mixture. Pkt. 5c. Mixed from above and other kinds. Pkt. $5 \mathrm{c}$.

\section{BALOON VINE--LOVE IN A PUFF}

$A$ rapid growing climber; thrives in light soil. One of the prettiest climbers. Pkt. 5c.

\section{BALSAM APPLE--MOMORDICA}

Curiously trailing vines; with ornamental foliage and odd shaped fruit which, when ripe, open, showing a brilliant red interior. Pkt. 5c, oz. 25c.

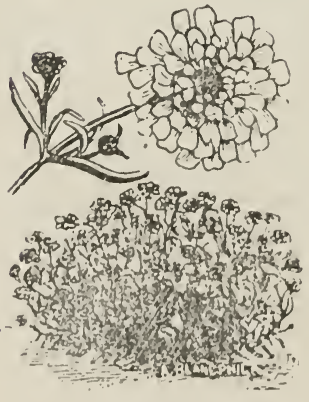

CANDYTUFT

\section{BATCHELOR'S BUTTON}

Hardy annual; flowers freely in almost any situation. For cut flowers they are largely used.

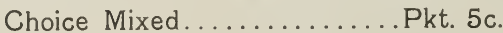
White ................... " $5 \mathrm{c}$. Brilliant Rose............. "5c. Purple ............... "5c.

\section{CANDYTUFT}

Universally known and cultivated. Considered indespensible for cutting.

White Rocket.............Pkt. 5c. New Carmine ............... "5c. Mixed Colors .......... 20. 20c. " 5c.

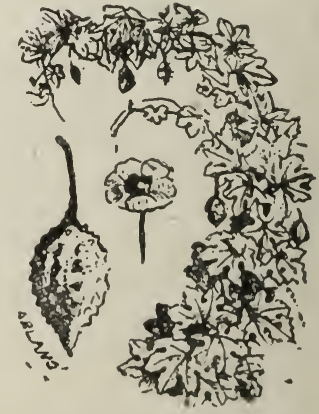

BALSAM APPLE 


\section{CALENDULA-POT MARIGOLD}

FREE BLOOMING AND ATTRACTIVE PLANTS, GROWING WELL IN ALL SITUATIONS

Meteor-This magnificent variety has large and beautiful imbricated double flowers. with stripes of deep orange on a pale yellow ground. Pkt. 5c.

Fine Mixed -Pkt. $5 \mathrm{c}$, oz. $25 \mathrm{c}$.

\section{COLEUS}

Mixed-Splendid selection. Pkt. $5 \mathrm{c}$.

\section{COBAEA}

A fine rapid growing climber, large bellshaped flowers, beautiful deep violet blue. Pkt, 5c.

\section{COSMOS}

A magnificent race of plants growing about three to four feet high, and in fall literally covered with graceful flowers resembling single dahlias, but better for cutting. As a cut flower for vases or personal wear, its grace and beauty are unequaled.

New Early Blooming-Coming into bloom in about two months from time of sowing and continuing until destroyed by frost. The plants have fine feathery, light green foliage and delicate rose, purple, white

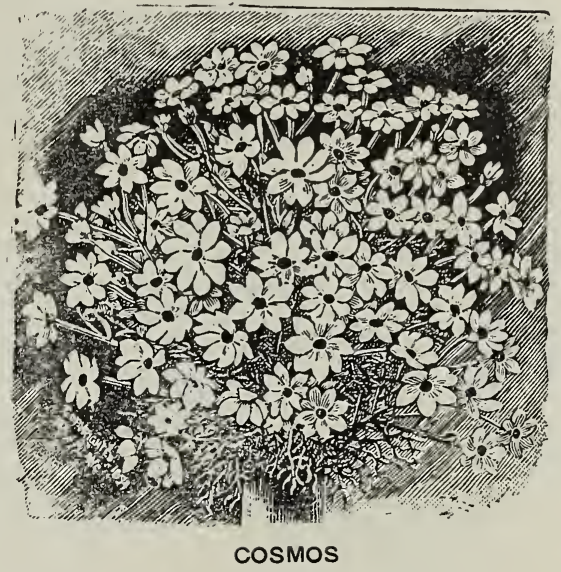
and lilac flowers. Mixed colors. Pkt. 5c.

Mammoth Perfection-Flowers double the size of the old large flowering Cosmos. measuring twelve to fifteen inches in circumference; the petals are broader and overlapping: flowers white, pink or crimson. Pkt. 5c.

Woodside Early Flowering-Pkt. 5c. Lady Lenox - See Novelty page.

\section{CANNA}

Are erect and stately plants, from two to six feet in height. The leaves are green in some varieties, and in some purplish and reddish. The flowers are bright colors, red or yellow, and variously marked. Pkt. $5 \mathrm{c}$.

\section{CYPRESS VINE}

This is a most beautiful climber, with delicate dark green feathered foliage, and an abundance of bright, star-shaped rose, scarlet and white blossoms.

White ......Pkt. $5 \mathrm{c}$, oz. 25c

Rose .........Pkt. 5c, oz. 25c
Scarlet ......Pkt. 5c, oz. 25c

Mixed ......Pkt. $5 \mathrm{c}$, oz. $25 \mathrm{c}$

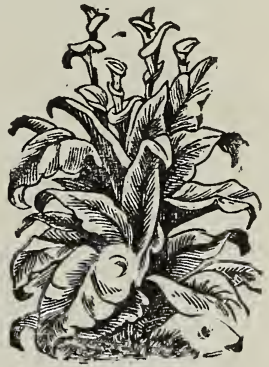

CANNA

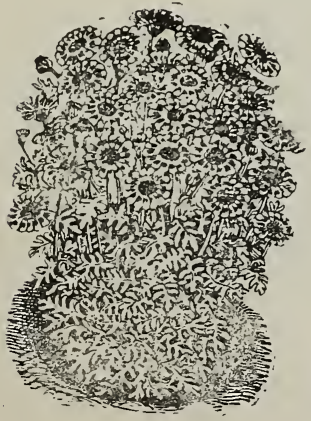

CHRYSANTHEMUM
CALLIOPSIS-COREOPSIS Pkt. 5c.

Mixed Colors of every shade.

\section{CHRYSANTHEMUMS}

The flowers are borne on long stems, and are represented by a great variety. The single ones are particularly handsome. Pkt. 5c.

A nice lawn adds greatly to the value of any place. It is easily, quickly and cheaply made by using our Lawn Grass seed described on another page.

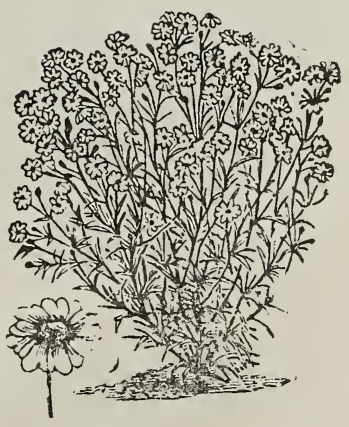

CALLIOPSIS 


\section{COCKSCOMB}

Producing crested heads of flowers, resembling a cock's comb. Fine Mixed, Pkt. 5 c.

\section{CUCUMBER \\ WILD}

A handsome, hardy climber, valuable for covering unsightly objects, tree stumps, etc. It is a rapid grower, attaining a height of twenty-five to thirty feet. The beautiful green foliage is dotted over with small white flowers, which develop into small prickly fruit, making an attractive display throughout the entire season. Pkt. $5 \mathrm{c}$.

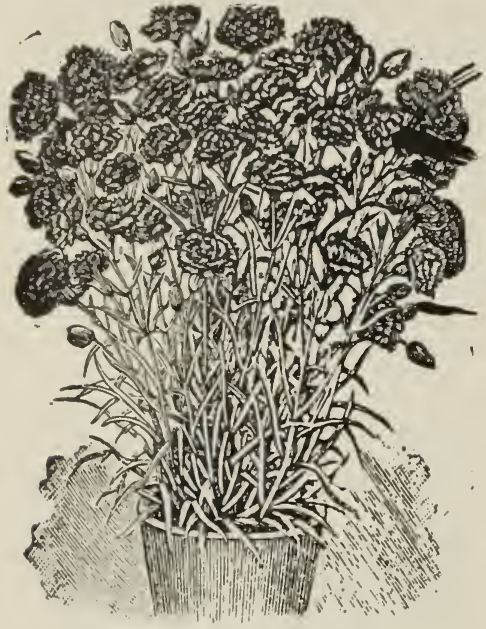

CARNATION

\section{CARNATIONS}

The most magnificent of all the Pink family, and are general favorites for their delicious fragrance and richness of coior. Pkt. 5c.

\section{MARGUERITE CARNATIONS}

Without exception the most abundant bloomers of all. The flowers are of perfect form, large and very sweet-scented. The different colors range through many beautiful shades of red, pink white, variegated. Pkt. 5c.

\section{CAMPANULA \\ CANTERBURY BELL}

The Campanulas are a very large genus of showy plants, mostly perennial. The Campanula, medium (Canterbury Bell) claims a situation in all gardens. Easy of culture and certain to flower, all succeed well in good soil. Plant $8 \times 12$ inches. Pkt. 5c.

\section{DIGITALIS \\ FOXGLOVE}

Handsome, stately growing plants, with beautiful mottled. thimble shaped flowers; produced in profusion on a stem usually about three feet high. The racemes. of flowers are about two feet long. Fine Mixed, Pkt. 5c.

\section{DOUBLE DAISY}

Give it a cool, partially shaded place. Sow seeds very early. The flowers are abundant in early spring, and may be made to flower later by the use of water.

Longfellow_- Has very double dark rose flowers; come true from seeds, of unusual size. Pkt. 5c.

Snowball A large and very double pure white Daisy of the Longfelıow type. Flowers on long stems, excellent for cutting. Pkt. 5c. $5 c$.

Double Mixed Finest German Seed. Pkt.

Swan River Daisy A dwarf free-bloomer. excellent for baskets and edgings: blue flowers. Pkt. 5c.

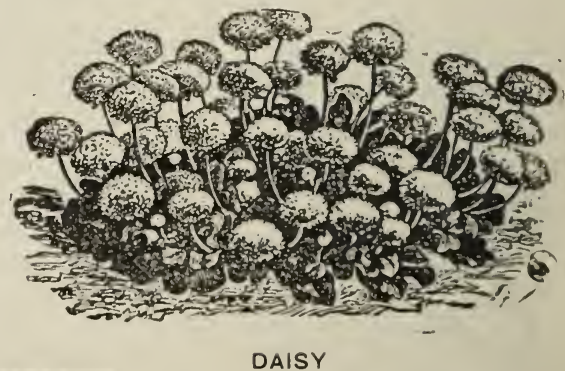

A nice lawn adds greatly to the value of any place. It is easily, quickly and cheaply made by using our Lawn Grass Seed described on another page. 


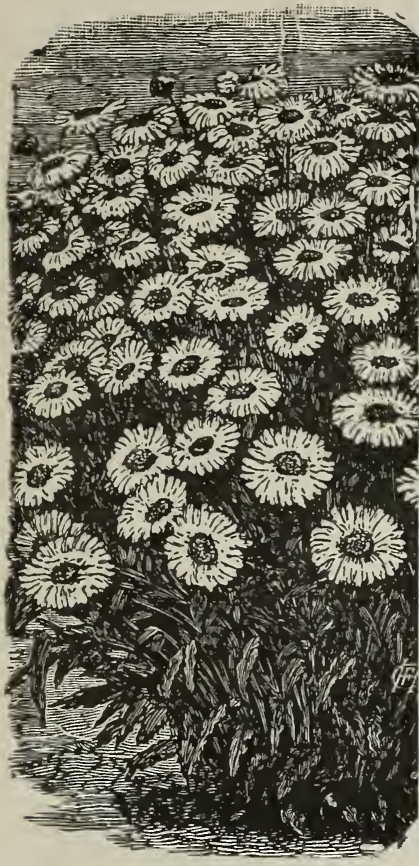

BURBANK'S SHASTA DAISIES

\section{BURBANK'S SHASTA DAISIES}

Can be grown out of doors by everybody where it is not cold enough to kill the oak trees. They are perennial, blooming better and more abundantly each season. They can be multiplied rapidly by simple division, and they are not particular as to soil. They bloom for several months, in California nearly all the year. The flowers are very large and graceful, averaging about four inches, often more in diameter, with three or more rows of petals of the purest whiteness, on single, strong, stiff, wiry stems, nearly two feet in length. Pkt. 10c,

\section{DIANTHUS PINK}

All of this beautiful class of Pinks are hardy and will flower the second season if not allowed to flower too freely the first season,

\section{DOUBLE VARIETIES}

Chinese Double, Mixed... Pkt. 5 e

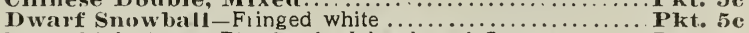
Dwarf Hireball-Blood-red. globe-shaped flowers........... Pkt. 5e Choice Double, Mixed-Splendid for boquets.............. Pkt. 5c

\section{DAHLIAS}

Many people are not aware that Dahlias from seed sown in the spring will bloom beautifully the first summer, and give quite as good, if not better satisfaction than bulbs.

Double Larse Flowering-Choice mixed, from selected flowers

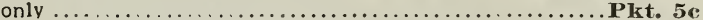

New Single-Mixed colors. The fiowers of Single Dahlias are large, periectiy star-shaped, formed of broad petals, which are gay and beautiful in color.................................... Burbank's Dahlia Seed-See Novelties, page 2.

\section{NEW DAHLIA}

\section{"TWENTIETH CENTURY"}

The New Orchid Flowered Dahlia -The flowers are very large, single, $41 / 2$ to 6 inches in diameter, of perfect form and exquisite finish. The color is intense rosy crimson with white tips and white discs around the yellow center. The color contrasts are exquisitely lovely and can be compared with the beautiful orchids. The flowers have stems two to three feet long, keeping a long time after being cut in perfect condition. In addition to the rare beauty of the flower it combines a sweet fragrance. Pkt. 10c.

\section{FORGET-ME-NOT}

The Forget-Me-Not is an old and favorite plant, bearing clusters of star-shaped, delicate blue flowers with white and yellow eyes. Pkt. 5c.

\section{FOUR O'CLOCK MARVEL OF PERU}

Old-fashioned, but none the less beautiful; makes a pretty hedge. Flowers are funnel-shaped, white and striped, very fragrant. and open about four o'clock in the afternoon, remaining open all night.

Hybrir Mixture......................... Pkt. se. oz. 25.

\section{ORNAMENTAL GOURDS \\ A GOOD CLIMBER}

Most sorts are good for twenty to thirty feet in a season, and the blossoms of some are striking and handsome. With all sorts the fruit is unique and ornamental, and often useful. If you have an old tree, dead or nearly so, Gourds will cover it to perfection. The small, fancy gourds are excellent toys for children, while the larger gourds may be used as dippers. Mixed, many beautiful varieties, pkt. 5c, oz. $30 \mathrm{c}$.

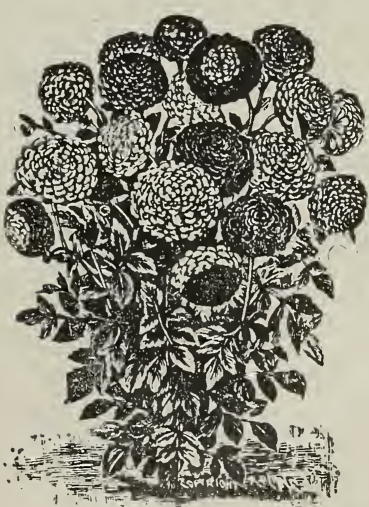

DAHLIAS 


\section{GAILLARDIAS}

Of magnificent and wonderful profusion, the flowers are greatly admired for their fine forms and rich blending of colors: they thrive anywhere.

Fine Mixed Varieties, Pkt. 5c.

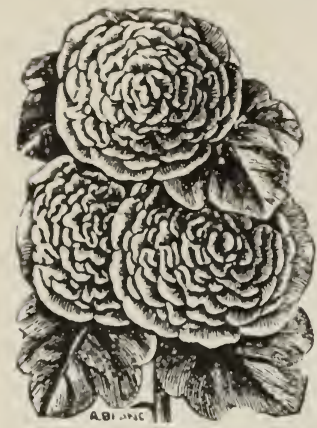

HOLLYHOCKS

\section{HOLLYHOCK}

For a background to a flower garden perhaps no plant is so useful. The flowers are as double as the Rose, of many shades of color.

Double Pure White $\quad$ Pkt.

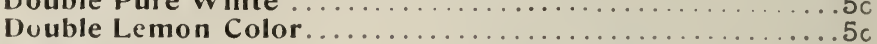

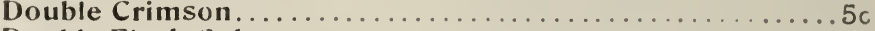

Double Flesh Color........................

Extra Choice-Double mixed, many kinds.............

Mammoth Flowering "Allegheny Hollyhocks"-From four to six inches in diameter, ranging from semi-double to double. and finely fringed and curled. The colors are shell pink, rose and ruby red, a shade or two deeper at the center and exquisitely tinted towards the edge.

Everblooming ............................. $5 \mathrm{c}$

\section{HYACINTH BEAN}

A rapid growing plant, flowering freely in clusters. For covering arbors, trellises, etc. Sow the seed in the garden where desired. Mixea-Pkt. 5c.

\section{HUMULUS}

A rapid growing climber, with luxuriant foliage; excellent for covering verandas, etc Withstands heat and drouth well, and is not covered with insects.

Variegated Japan Hop-Pkt. 5c.

\section{HELIOTROPE}

Flowers purple, borne in trusses, and exceedingly fragrant, Delights in light, rich soil.

Extra Choice Mixed, Pkt. 5c.

\section{HIBISCUS}

These immense flowers are pure white, with a large crimson eye, often measure seven inches in diameter, and a plant will often have as many as fifty of them. It blooms from seed the first year, sown in the open ground. A perennial, and lasts year after year. Pkt. 5c.

\section{JOB'S TEARS}

An old-fashioned but valuable remedy for sore throat. goiter and teething babies, when the seed is strung on linen

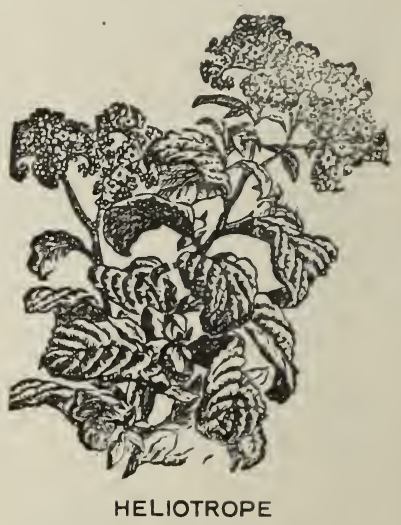
thread and worn around the neck as a chain. They are cheaper than amber beads, which are used for the same purpose, and are a sure cure. Two ounces make a chain. Pkt. 5c. oz. $15 \mathrm{c}$.

\section{KOCHIA, OR "BURNING BUSH"}

Kochia Tricophylla $\AA$ highly ornamental annual of unusually rapid growth, which forms regular pyramids from two to three feet in height, having a cypress-like appearance. The leaves are slender and of a light pea-green until September, when they change to carmine and blood-red. Its bright autumn coloring has given it two other names, "Mexican Fire Plant" and "Burning Bush." Pkt. 5c.

\section{LARKSPUR}

Producing beautiful spikes of double flowers in many colors. If sown early in the spring they will flower in June or July. Pkt. 5c. 


\section{LINUM \\ Grandiflorum Rubrum-(Scarlet flax). \\ LOBELIA}

The profusion of their charming little flowers render them extremely ornamental. Very fine for hanging-baskets,

Crystal Palace-Dark blue, splendid..............Pkt. 5c

\section{MIGNONETTE}

It is in bloom nearly the whole season, and the perfume is so strong and fragrant that the whole atmosphere around is perfumed.

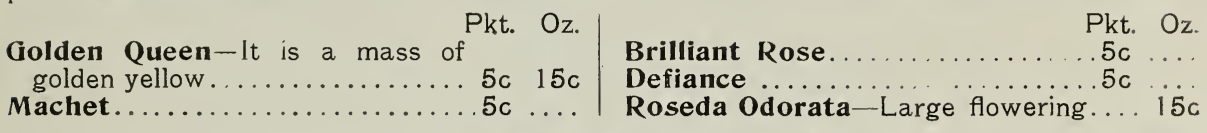

\section{MOON FLOWERS}

Beautiful climbers and exceedingly attractive, mixed with other climbers. Flowers of graceful form. Pkt. 5c.

Japanese Imperial Morning Glories - Their varieties of color are infinite, running from snowwhite through all possible shades of blue and of red, from palest pink to darkest reds and purples. They are streaked, mottled, striped, marbled and bordered in wonderful fashion, and sometimes show rare shadings of ash-gray, bronze, terra cotta, brown and slate-blue, colors rarely found in any other flowers. The leaves are also very handsome. Pkt. 5c, oz. 25c.

Double Flowering-They are white, with a slight spot of red or blue at the base of the larger petals. About eighty per cent. of the seedlings will reproduce themseives true from seed. When sown early in the spring, a long season of beautiful double flowers will repay you. Pkt. 5c.

Morning Glory-Suitable for covering arbors, windows, trellises, old stumps, etc. It is so perfectly hardy as to grow in almost any soil. Mixed pkt. $5 \mathrm{c}$, oz. $15 \mathrm{c}$.

\section{NICOTIANA}

\section{(SWEET SCENTED TOBACCO PLANT)}

An annual with sweet-scented, pure white, star-shaped flowers, three inches across, blooming continually. If the plants are taken up in the fall, cut back and potted, they will bloom nicely in the house during the winter. Two to three feet. Pkt. 5c.

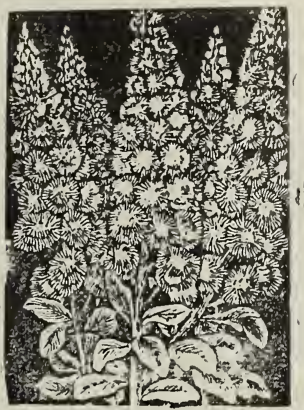

MIGNONETTE

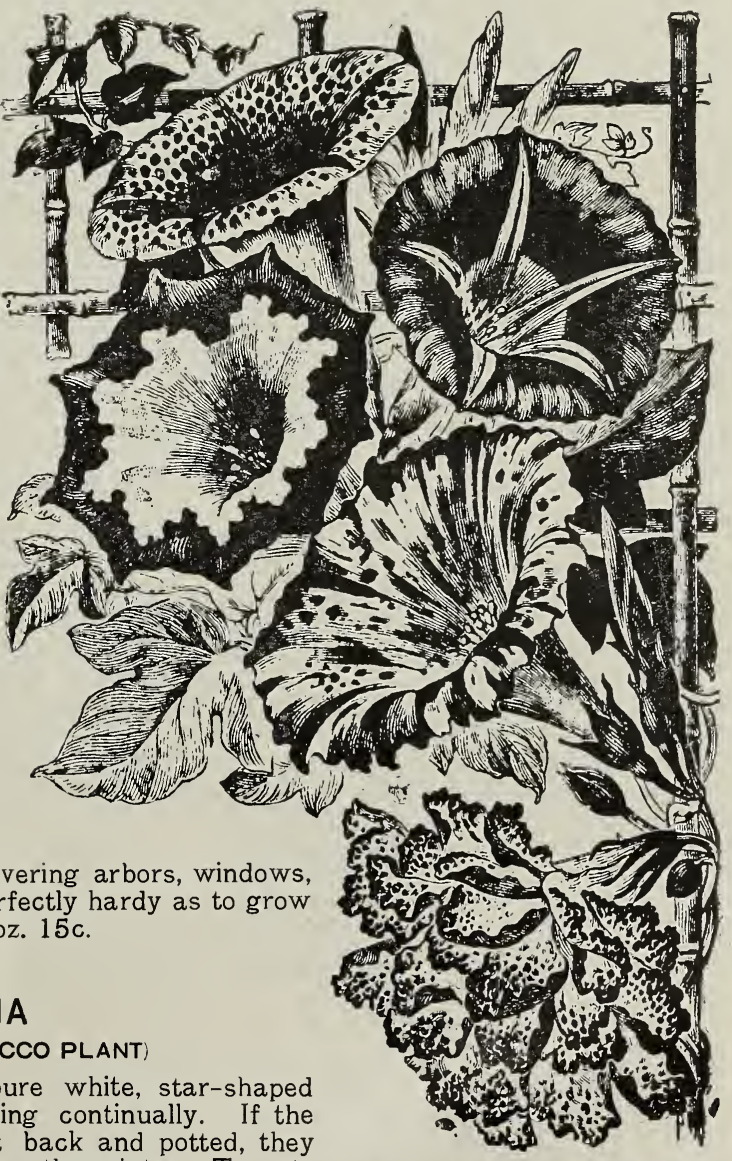

JAPANESE MORNING GLORY 


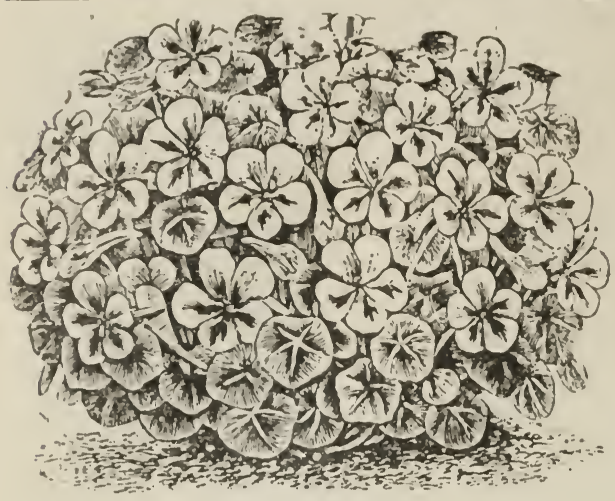

NASTURTIUMS

\section{NASTURTIUMS}

Should not be planted in too rich soil. The dwart varieties are among the most useful of annuals, for bedding, massing, etc., owing to their comract growth. richness of color and profusion of bloomers. The tall sorts are admirably adapted for rock work, covering trellises or rustic work.

\section{DWARF NASTURTIUMS}

Empress of India-Foliage purple blue, bearing brilliant, deep scarlet flowers, a profuse bloomer of a most showy class. Pkt. 5c, oz. 20 c.

King of Tom Thumbs-Quite distinct, leaves very dark, flowers rich crimson; a very brilliant, effective sort. Pkt. 5c, oz. 20c.

Bronze Curled-Flowers of bronze, metalic lustre, a very distinct color. Pkt. 5c. oz. 20c.

Cattel's Crimson-Showy variety, equal to any in startling effect. Pkt. 5c, oz. 20c.

Pearl-Flowers white, a rare color among Narsturtiums, producing a pleasant effect.

Pkt. 5c, oz. 20c.

King Theodore-One of the best dark red sorts, with dark, blush green foliage; a great favorite with florists. Pkt. $5 \mathrm{c}$.

Mixed Dwarf Sorts-A mixture of the best dwarf sorts, producing when in bloom an agreeable effect of colors of scarlet, crimson, bronze, gold and white. Pkt. 5c, oz. 15c.

Queen of Tom Thumbs-See Novelties.

\section{TALL NASTURTIUMS, THREE TO TEN FEET}

Pearl Delicate creamy-white flowers, contrasting finely with the orange, gold and scarlet of more brilliant varieties. Pkt. $5 \mathrm{c}$, oz. $20 \mathrm{c}$.

Spit Fire-Remarkable in its intensity of startling brilliancy; one of the finest sorts. Pkt. 5c, oz. 20c.

Bright Rose-Very choice sort, producing a rose colored flower. Pkt. 5c, oz. 20c.

Dunnett's Orange - A very vigorous grower, producing a showy, deep orange flower. Pkt. 5c, oz. 20c.

Chameleon - On one and the same plant are found self-colored flowers, others stained and blotched on a clear ground, while others are broadly edged or banded with light or dark shades. Pkt. 5c.

Golden Cloth-Distinct and striking. The foliage is of a bright yellow while the flowers are intense scarlet. Pkt. 5c.

New Climbing Nasturtium. Mme. Gunther's Hybrids-For richness and variety of colors, these new Hybrids have no equal among Nasturtiums. There are shades of rose, salmon, brightest rose, pale yellow; either as self colors or striped and spotted. The foliage is mostly dark and contrasts very effectively with the rich colors. They are climbers and continuous bloomers. Contains a great many colors that are not found in any other mixture. Pkt. 5c, oz. 20c.

Black Prince-(New Climbing) - Undoubtedly the darkest colored variety amongst the whole collection of Lobb's Climbing Nasturtiums. The plants are of strong, vigorous growth and produce their flowers very freely. When unfolding their buds the color is a deep blackish-purple, which changes to a velvety-black when in full bloom. The shade of color is much darker than that of the well-known "King of the Black." The foliage is exactly as rich and dark as that of the Dwarf Nasturtium "Empress of India." Very effective. Pkt. 5c.

Virchow-(Climbing) - The flowers are of a distinct ruby-rose, shading into lighter and darker tints. Pkt. 5c.

Jupiter-(Climbing)-The flowers, which are very numerous, measure $31 / 2$ inches in diameter. They are exquisitely formed, with overlapping, crinckled petals. The color is a bright golden-yellow, with a glow of orange around the throat. Pkt. 5c.

Mixed Tall Sorts - $A$ combination of many tall varieties: colors, white, cardinal, orange, rose. scarlet, etc. Pkt. 5c, oz. $15 \mathrm{c}$.

\section{PORTULACA} ROSE MOSS

Makes a dazzling display of beauty; many hued, highly colored; are in bloom from about the first of July until frost. Plant in open ground, after it has become warm, in light, sandy soil and in a dry situation. Bed should be exposed to the sun. Double Rose=Flowered Perfectly double. of many brilliant colors, as well as striped. Pkt. 5c. 


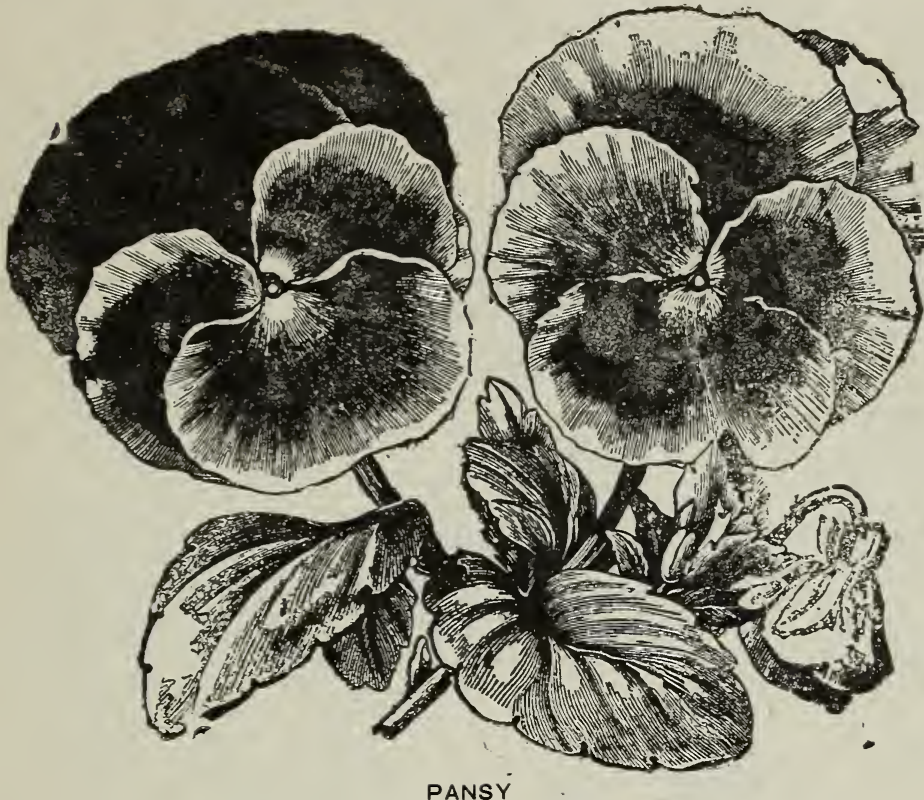

PANSY

\section{PANSY}

This superb collection cannot be surcassed for size, shape, markings or richness of color of the flowers. No pains are spared to make this strain absolute perfection in form, firmness of texture, size and freedom of bloom, and elegance and variety of markings and colorings.

BUGNOT S-A celebrated French strain; very large. Pkt. 10c.

CASSIER:S FIVW BLOTCHED_Round flowers of great sub stance, with each petal finely blotched. Pkt. $10 \mathrm{c}$.

II STER PIECEFrilled and curled. The flowers are very large, borne very freely well above the plant. Pkt. $10 \mathrm{c}$.

PKT.

PKT.

Odier Blotched Rich colors ........10c

English Show Mixture............

Azure Blue_Very fine ..........

Belgian Striped ...............10c

Black....................

Blue ........................

Emperor William Ultamarine blue...10c Giant White ................10c

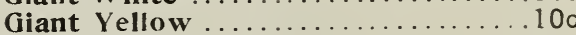

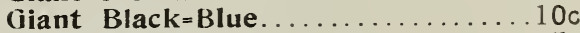

Gold Margined................

Mixed All above varieties and many others. Pkt. $10 \mathrm{c}$.

\section{POPPIES}

Showy and ornamental plants, with large flowers of brilliant colors. Very attractive in large beds. They are of very easy culture, and succeed in any garden soil.

Carnation Flower Splendid double flowers, mixed colors. Pkt. $5 \mathrm{c}$.

The Shireley_-Delicate shades of rose, pink and carmine to deep crimson. Pkt. 5c.

California Poppy - Of many brilliant and showy colors. Pkt. 5c.

New Oriental Hybrid Poppies_-For brilliancy of colors there is nothing to equal these Oriental Poppies. The flowers are of enormous size, often measuring over six inches in diameter, while the colors range from soft flesh and rose to the most brilliant, dazzling scarlet and richest maroon purple. Their culture is as simple as the garden Poppies. They are perfectly hardy perennials, living through our winters with but little protection and increasing in size and beauty from year to year. Pkt. 5c.

Poppy Marion_See Novelties, page 2.

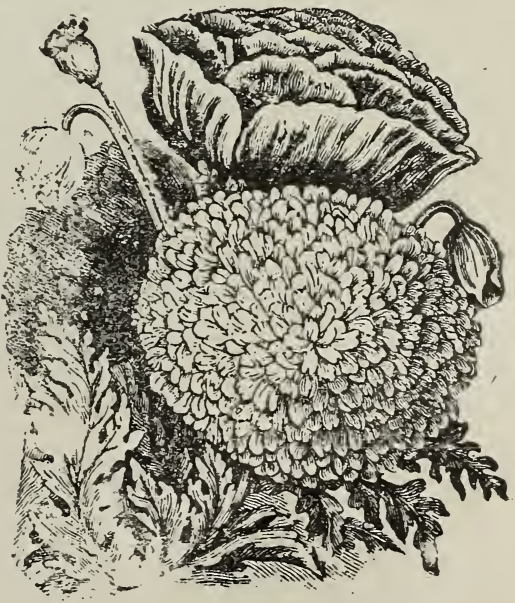

CARNATION POPPIES 


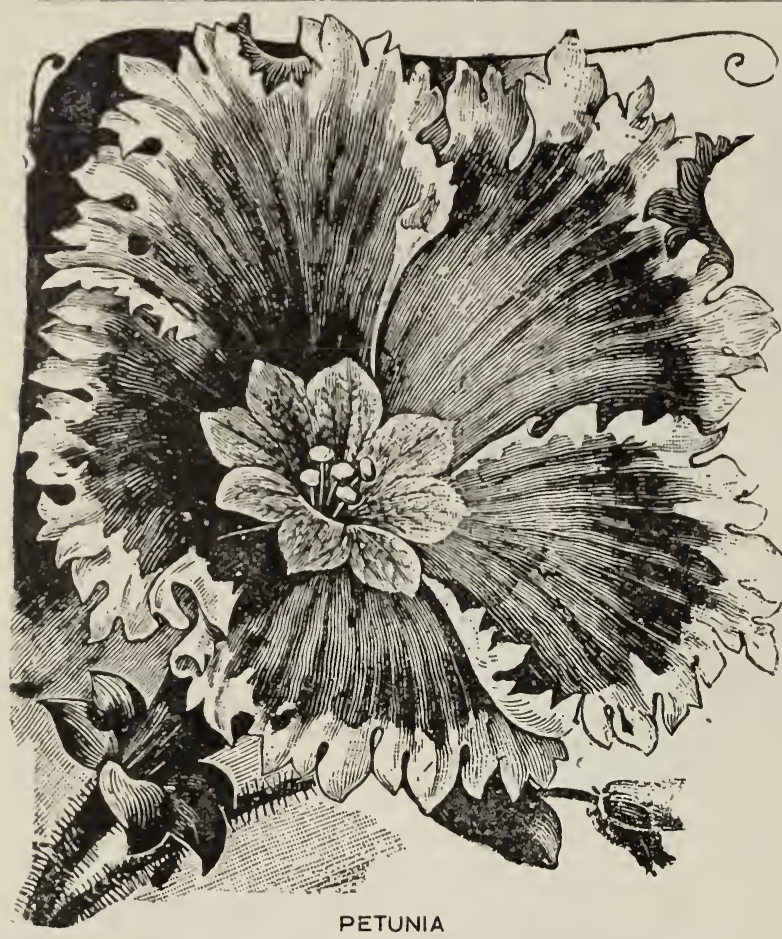

\section{PETUMIA}

Petunias will produce their handsome sweet scented flowers in their delicate and gorgeous colors throughout the whole summer. Pkt. 5c.

Petunia Giants of California-The flowers are very large, and the colors embrace every conceivable shade of crimson, white, violet, lavender, etc. Pkt. 10c.

See Novelty page.

\section{DOUBLE PETUNIA}

MIXTURE OF DOUBLE PETUNIAS

This is a mixture of the best large flowering and fringed double Petunias. Carefully hand fertilized and will produce grand flowers. Of course everyone knows that only a certain percentage of double flowers may be expected from seed, but our mixture will produce from 20 to 30 per cent. of doubles, while the remainder will be choice. large single flowers. Pkt. 25c.

\section{PHLOX DRUMMONDII}

The Phlox Drummondii, for splendid mass of colors and a constant display, is not excelled by any other annual or perennial. Pkt. 5c, oz. 75c.

Star Phlox - A regular star-like form, of compact habit, and bears large flowers. Pkt. 5c.

\section{RICINUS CASTOR OIL BEAN}

Magnificent, tall growing folıge plants, very useful as specimen plants on lawns or groups in center of large beds. Their brilliant leaves and fruits create a grand sub-tropical effect.

Barboniensis-Very large and handsome foliage: fifteen feet. Pkt. 5c, oz. 10c.

\section{SWEET WILLIAM}

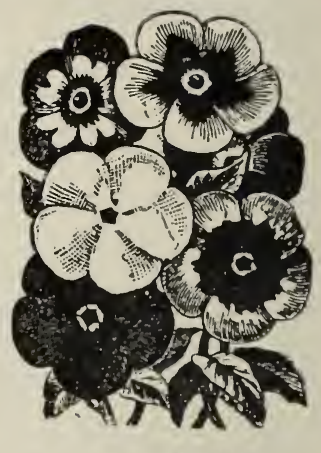

PHLOX DRUMMONDII

Giant Flowered Single-The single flowers are often as large as a twenty-five cent piece, and are simply enormous in comparison with the old time Sweet William. Pkt. 5c.

Giant Flowered Double-Like the above it is an improvement on the old-fashioned Sweet William, producing umbles of enormous size. Pkt. 5c.

\section{SMILAX}

Charming, tender perennial climber for window gardens. Pkt. $5 c$.

\section{NEW SALVIA}

Drooping Spikes - This new flowering Salvia (Scarlet Sage) has three times the flowering capacity on each spike of the ordinary Salvia Splendens. The flowers are produced in great numbers, causing the spikes to droop with their own weight. Pkt. 5c. 


\section{SWEET PEAS}

This mixture contains the cream of the new and standard sorts. It is made up entirely of new and separate sorts, carefully proportioned as to its composition, and we can safely say, "there is no better general mixture in existence." no matter at what price or under what name it may be offered.

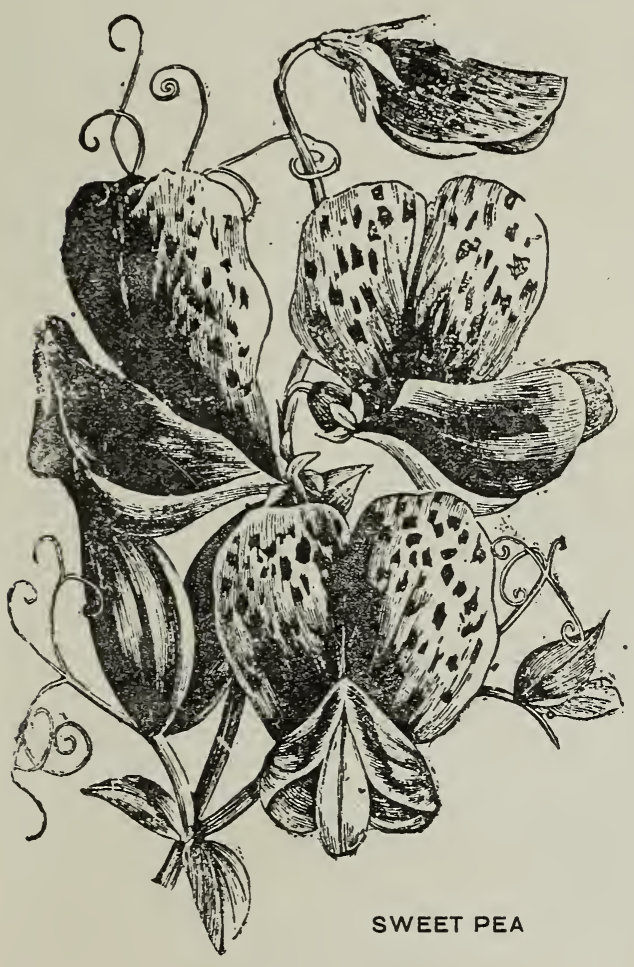

In planting the seed, it should be put into the soil in very early spring, to secure an early development, as early if not earlier, than the plan'ing of garden peas. If sown in rows, the trenches to receive the seed should be marked out three or four inches deep and half filled with manure, and the seeds placed half an inch arart, the plants to be finally thinned to three inches arart. Planted in single rows, one ounce of Sweet Peas will seed twenty feet: but for effective purposes one ounce should be allowed to every ten feet, or even less.

\section{PINK AND SCARLET CLASS}

Fairy Queen-White, penciled with pink. Pkt. ǰc. oz. $10 \mathrm{c}$.

Lady Beaconsfield-Yellowish white with rosy wings. Pkt. 5c, oz. 10c.

Lottie Ekford-White, shaded with pink and indigo. Pkt. 5c, oz. inc.

Mrs. Gladstone-Fale rose and buff. Fine large fiower. Pkt. 5c, oz. 10c.

Blushing Beau1y $-\AA$ heliotrore pink suffused with lilac. Pkt. $5 \mathrm{c}$, oz. $10 \mathrm{c}$.

Venus-Rose with buff and decided sulphur tint Pkt. 5c, oz. 10c.

Katherine Tracy-Brilliant pink. Pkt. 5c, oz. 10c

Gaie1y-Magenta and white striped, very desirable. Pkt. 5c, oz. 10c.

Queen of the Isles-Carnation flowered, white and striped. Pkt. 5c, oz. 10c.

Apple Blossom-Bright, rosy, pink and white. Very choice. Pkt. כ́c, oz. 10c.

Improved Painted Lady-Rosy, crimson and white. An excellent short vine. Pkt, 5c, oz. 10c.

Lady Penzance-Bright rose and pink. Very fine. Large flower. Pkt. 5c, 0z. 10c.

Her Majesty-Rich. deep scarlet rose. Very fine One of the best. Pkt. כc, oz. 10c.

Firefly-Brightest of the iscarlets. Fine, solid color. Pkt. 5c, oz. 10c.

Triumph-Bright pink suffused with orange-scar let. Pkt. 5c, oz. 10c.

Extra Early Blanch Ferry-Wings white, shading to purplish pink. Pkt. כ́c, oz. 10c.

Balopian-One of the best of the dark reds. Pkt. ōc, oz. 10c.

Mrs. Joseph Chamberlain-Whlte, striped with deep clear rose. Pkt. jc, oz. $10 \mathrm{c}$.

Red Rilling Hood-Pink, shading to blush white. Pkt. 5c, oz. 10c.

Lovely-Soft shell pink. Pkt. 5c, oz. 10c.

Agnes Johnson-Deep pink, shaded cream. Pkt. j̃c. oz. $10 \mathrm{c}$.

George Gordon - A carmine crimson, standard, wings lavender. Flowers very large. Pkt. 5c, oz. $10 \mathrm{c}$.

Golden Rose-The flowers are extra large. Color, primrose-yellow flushed with rosy pink. Pkt. 5c, oz. $10 \mathrm{c}$.

Gracie Greenwood-Soft salmon pink: distinct edg ing of deeper pink. Pkt. 5c, oz. 10c.

Janet Scott-A rich, deep pure pink, flowers very large size. Pkt. 5c, oz. 10c.

Jeanie Gorden - The standards bright, rose shaded cream. Flowers large; a charming variety. Pkt. sc, oz. $10 \mathrm{c}$.

King Edward VII-A true giant flowered variety, with no inclination to burn in the sun. $A$ fine variety, in fact the best dark red in existence. Pkt. כ́c, oz. 10c.

Lady M. Ormsby Gore-Color, primrose delicately shaded with butf. Pkt. 5 c, oz. 10c.

Lord Roseberry-Color, rosy carmine, with deeper veins. Pkt. $5 \mathrm{c}$, oz. $10 \mathrm{c}$

Majestic-Rich, deep, rosy pink. Pkt. ãc, oz. 10c.

Miss Wilmot-Standards rich, deep orange, pink. wings a shade lighter. Pkt. כ̇, oz. 10c.

\section{WHITE CLASS}

Blanche Burpee-The finest pure white. Blossoms freely. Pkt. 5c, oz. 10c.

Sensation-Pkt. $5 c$, oz. $10 c$.

Sadie Burpee-Large size. Purest white. Pkt. óc. oz. $10 \mathrm{c}$.

Mrs. Sankey-Pure white flowers, large. Pkt. õc. oz. $10 \mathrm{c}$.

Emily Henderson-Pure white. Earliest to flower Pkt. 5c, oz. 10c.

White Wonder-The flowers are pure white of the largest size and are borne six to eight and frequently as many as ten to twelve large flowers on a long stout stem. The stems are frequently double. Pkt. $5 \mathrm{c}, \mathrm{oz} .10 \mathrm{c}$. 


\section{PURPLE AND BLUE CLASS}

Black Knight -Rich, glossy, blackish-maroon.....................

Captain of the Blues - Purplish flower, wings deep blue ...............

Princess of Wales-Lavender, purple, mauve and carnation, striped.........

Boreaton-Purple-crimson, very dark, velvety-maroon, distinct color.........5c 10c

Countess of Radnour-Delicate lavender and reddish mauve. Very superior....5c 10c

Emily Eckford Violet blue, best of that color. Large bold flower............5c 10c

Dorothy Tennett - Showy, purple blue, fine variety................. $5 \mathrm{c}$ 10c

Grand Blue-Body royal blue, blue-crimson standard..................

\section{YELLOW CLASS}

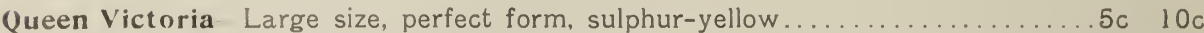

Golden (ileam - Deep prımrose tinted ........................... $10 \mathrm{c}$

Meteor-Orange, salmon, wings pinkısh hue................. $10 \mathrm{c}$

Mrs. Eckford-Light canary, nearly yellow...................... $10 \mathrm{c}$

\section{MIXED CLASS}

First Selection $A$ All the above sorts mixed, Lb. $\$ 1.00,1 / 4 \mathrm{lb} .25 \mathrm{c} \ldots \ldots \ldots \ldots \mathrm{c} \quad 10 \mathrm{c}$

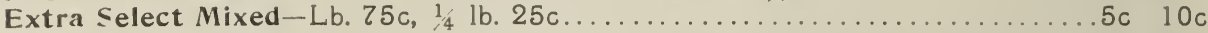

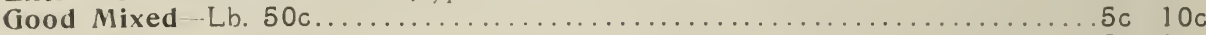

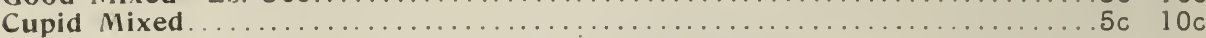

\section{DOUBLE SWEET PEAS}

The varieties we offer will, under ordınary circumstances, produce a large percentage of double flowers. These double flowers are very attractive, being waved and crimped, with none of the usual stiffness of double flowers. Our mixture is composed of very choice sorts, representing a wide range of colors. Pkt. 10c, oz. 15c, lb. $\$ 1.00$.

Stocks, Ten Weeks-Are greatly prized for cut flowers on account of their fragrance and diversity of color. Fine mixed, pkt. $5 \mathrm{c}$.

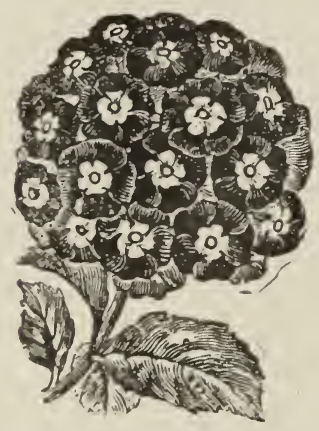

VERBENA

\section{VERBENA}

One of our finest bedders, displaying a great variety of shades. Plants from seed produce more flowers than those from cuttings.

Pkt.

Extra Choice Mixed-Very fine.................

Scarlet Defiance-Glowing scarlet.............5c

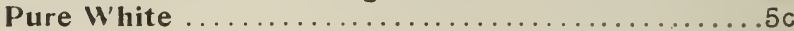

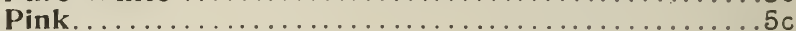

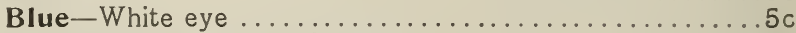

Auricula Flowered-Striped ...............

\section{THE WILD-FLOWER GARDEN}

Our Wild-flower mixture consists of many varieties of beautiful, easy-growing flowers, producing a constant and varied bloom the whole season, for sowing in shrubbery, under trees and in beds, on which no care will be bestowed, or even for sowing

in exposed situations, where wildness is preferred to order and precision. Large pkt. 5c.

\section{ZINNIA}

The Zinnia is a beautiful annual and general favorite, its splendid double flowers rivalıng in beauty, size and form, moderate sized Dahlias. They bloom until frost sets in.

Mixture of Colors-Colors finest strain. Pkt. 5c.

Pure White Pkt. 5c, oz. 50c.

Dwarf Scarlet-Pkt. 5c, oz. 50c.

Golden Yellow-Pkt. 5c, oz. 50c.

Double CrImson-Very double. Pkt. 5c, oz. 50c.

Double Pink-Pkt. 5c, oz. 50c.

Carnation Striped-Flowers are of perfect form, double and as finely striped as a Carnation. Pkt. 5c, oz. 50c.

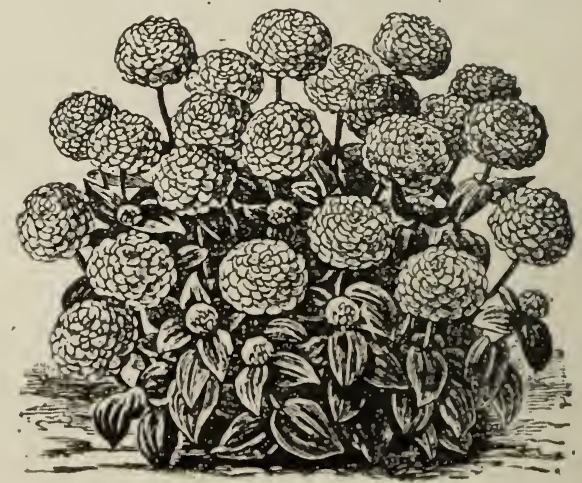

DWARF ZINNIAS 


\section{HARDY PERENNIAL PLANTS.}

No home ground is complete without a collection of hardy perennial plants and bulbs, and the demand for these is increasing wonderfully with every succeeding season. We have simply been astounded at the ever growing interest in ornamental gardening all over this country. We are growing the best stocks of these subjects, as will surely give every satisfaction to beginners as well as experts. By proper selection, one may have flowers in abundance from April to November, and a pleasing picture by proper arrangement for color effect. The plants may be arranged in formal designs or along the shubbery border. They bloom so freely that one may cut and come again, and are so easily grown that anyone may succeed with them. Moreover, the cost need deter no one from having a choice selection, since the plants are permanent, and once planted remain from year to year with but little care and hardly any winter protection in our climate. We have a very fine lot of these plants of our own growing. They are well rooted and sure to give entire satisfaction. Many perenniai plants are mere weeds. The list offered below has been carefully selected, and and comprises only varieties of real merit:

Aquilegia-Columbine-The distinct, clear cut foliage and delicate arrangement of colors in the flowers of Columbine make it one of the showiest and most desirable of the hardy garden plants, especially suitable for rock work, at the base of foundation walls and under trees. Each 10c, doz. \$1.00.

Bleeding Heart - Dielytra Spectabills-Pretty spring bloomers, with graceful, drooping sprays of heart-shaped pink and white flowers; very ornamental and bloom freely early in the season. Hardy, increase in size from year to year. Each $25 \mathrm{c}$ and $35 \mathrm{c}$.

Boltonia Asteroids - This beautiful hardy perennial grows to a height of four feet and is very showy when covered, during the summer and autumn, with its countless pure white, single, asterlike flowers. Valuable for cutting. Each $15 \mathrm{c}$, two for $25 \mathrm{c}$, doz. $\$ 1.50$.

Coreopsis Lanceolata - A beautiful hardy border plant fifteen to eighteen inches high; bright golden-yellow flowers in great profusion the entire season. A handsome vase flower for table decoration. Each 10c, doz. $\$ 1.00$.

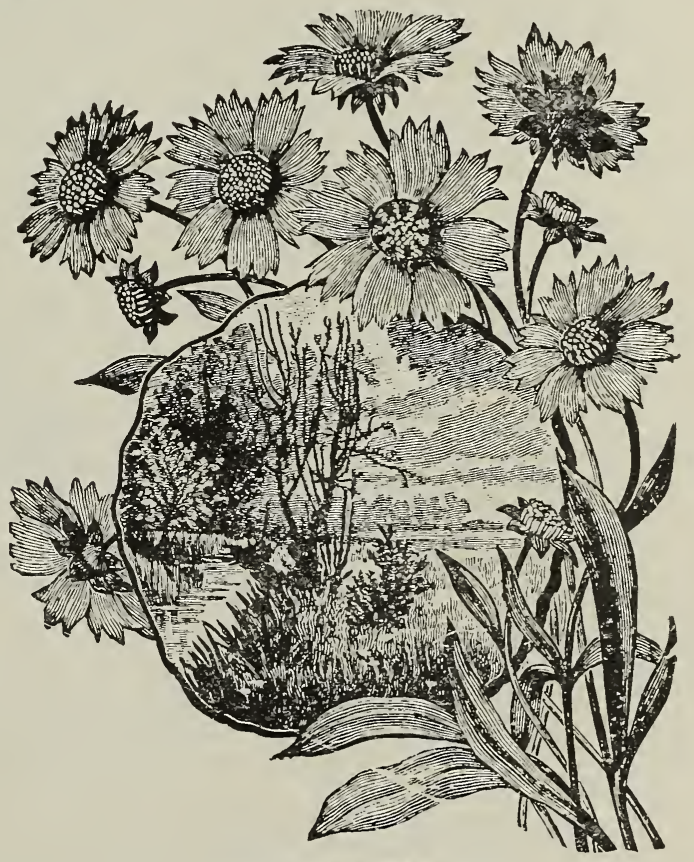

BOLTONIA ASTEROIDS

Digitalis-Fox Glove-A choice garden variety in mixed colors, including white. Each 15c, doz. $\$ 1.50$.

Giant Daisy-Great $\mathbf{0 x = e y e}$ or Giant Daisy--Upright in growth, attaining four to five feet, with bright green foliage. White with bloom from mid-summer to autumn. The great snowy flowers have yellow centers, and are from two to three inches across. Each 15c, doz. $\$ 1.50$.

Daisies-Shasta-No other flower is of greater usefulness. They are very hardy; can be grown out doors, where it is not cold enough to kill oak trees. They are perennial, blooming better and more abundantly each season; can be multiplied rapidly by division of roots and are not particular as to soil. They bloom for several months -in California nearly all the year. The flowers are large and graceful, with three or more rows of petals of the purest glistening whiteness, borne on single stems nearly two feet in length. Each $15 \mathrm{c}$, doz. $\$ 1.50$.

Funkia-Day Lilly-By some called Plantain Lilly. A superb autumn flower, desirable to plant on the side of lawns or at the edge of shubbery; succeeds in either sun or shady places. Fine for cemetery. Each $35 \mathrm{c}$. 


\section{HARDY PERENNIAL PLANTS-CONTINUED}

Golden Glow-Rudbeckia-A beautiful, hardy perennial, eight feet high, blooming from July to September. Flowers double, deep golden yellow, borne on long stems, making it suitable for cutting. One of the most effective decorative plants for garden or lawn. Each $10 \mathrm{c}$, doz. $\$ 1.00$.

(iaillardia Grandiflora-Blanket Flower-Of all hardy plants, the Gaillardia is very satisfactory. Begins to bloom in early summer and continues until after first frost. Perfectly hardy. Flowers two or three inches in diameter, with center of brownish red, while petals are shaded into rings of orange, crimson and red. Stems long; grand for cutting: does well in any soil. Each $15 \mathrm{c}$, two for 25c.

Hollyhocks -For planting in masses by itself, or as a background for lower growing plants, the Hollyhock plant cannot be dispensed with. Once planted they keep coming up year after year. Can supply the following separate colors: White, Lemon, Pink, Red and Maroon. Each 15c, dozen \$1.50.

Allegheny-We can this year offer you a splendid lot of these New Fringed DoubleFlowering Hollyhocks. Try them, they are fine. Mixed colors, each $15 \mathrm{c}$, doz. $\$ 1.50$.

Hibiscus-Crimson Eye-A robust grower, with dark stems and foliage. Flowers large, sometimes six inches across, purest white with large spots of deep velvet crimson in center. Perfectly hardy; blooms first year in open ground. Each $15 \mathrm{c}$, two for $25 \mathrm{c}$.

Vinca-Periwinkle-A well known evergreen traling plant, extensively used in the cemetery for covering grave mounds. It is also very valuable for carpeting under trees and in shady places, being an excellent substitute for grass. Each 10c, doz. \$1.00.

Achillea-The Pearl The flowers are borne in great profusion and are pure white, double; blooms all summer. Each 25c.

Hardy Poppies-Papaver Orientale - Nothing can equal this in gorgeous effect, and whether planted singly or in masses, their large flowers, rich coloring and freedom of bloom render them conspicuous in any position. They grow three feet high and bloom from May to August. Goliath-Flowers scarlet, of enormous size. Each 25c, doz. $\$ 2.50$.

Helianthus - Hardy Sunflowers-The perennial Sunflowers are among the most effective hardy plants for hardy borders, for planting among shrubbery or as clumps on the lawn. Multiflorus Plenus (Dahlia Sunflower) loaded with yellow flowers; excellent for cut flowers; five feet. August to September. Each 25c.

Hemerocallis-- Yellow Day Lilly. Each $15 \mathrm{c}$.

German Iris-Fleur=de=Lis-The German Iris is one of the most desirable early spring flowering plants. No garden is complete without a collection of these beautiful flags. Each 10c, doz. \$1.00.

Mixed Japanese Iris - We have a large mixed stock of extra fine bulbs in best varieties. and offer these at the following low price: $\$ 1.00$ per dozen.

Iris Sibirica Orientals, "Yale Blue"-Among the free-growing Iris, adapting themselves to almost any position, and producing a mass of deep blue flowers under the most adverse conditions from June to August. First size, each $15 \mathrm{c}$.

Pure Gold-Each 10c.

Mixed, all Colors-Each, 5c, doz. 50c. Fine for border or bedding.

Delphiniums - Hardy Larkspur - The Hardy Larkspurs are one of the most important and satisfactory plants in the herbaceous garden, and should be planted extensively even in the smallest garden. Their long spikes of flowers are produced continuously from June until late in the fall. Each $15 \mathrm{c}$, doz. $\$ 1.50$.

Platycodon-Balloon Flower or Japanese Bell Flower-The Platycodons are closely allied to the Campanulas, and form neat, branched bushes of upright habit, which bear a continual succession of flowers from June to October. Each 15c, doz. \$1.50.

\section{PAEONIES}

\section{WILL LAST A LIFETIME WITH LITTLE CARE}

These great big-hearted flowers grow from one to three feet high, producing the most magnificent blooms. The plants are never attacked by either insects, animal or fungal disease. Paeonies will succeed in most any kind of soil, but give best results when planted in a deep, rich and somewhat moist loam.

Humei-Immense, cinnamon centered pink. L'Esperence-Splendid, fragrant, early pink Queen Victoria-Standard white.

Andre Lauries-Late, fragrant, red.

Victoria Tricolor-Pink, cream and white.

Prices of above five kinds, each $25 \mathrm{c}$, the five for $\$ 1.00$. 


\section{HARDY PERENNIAL PLANTS-CONTINUED}

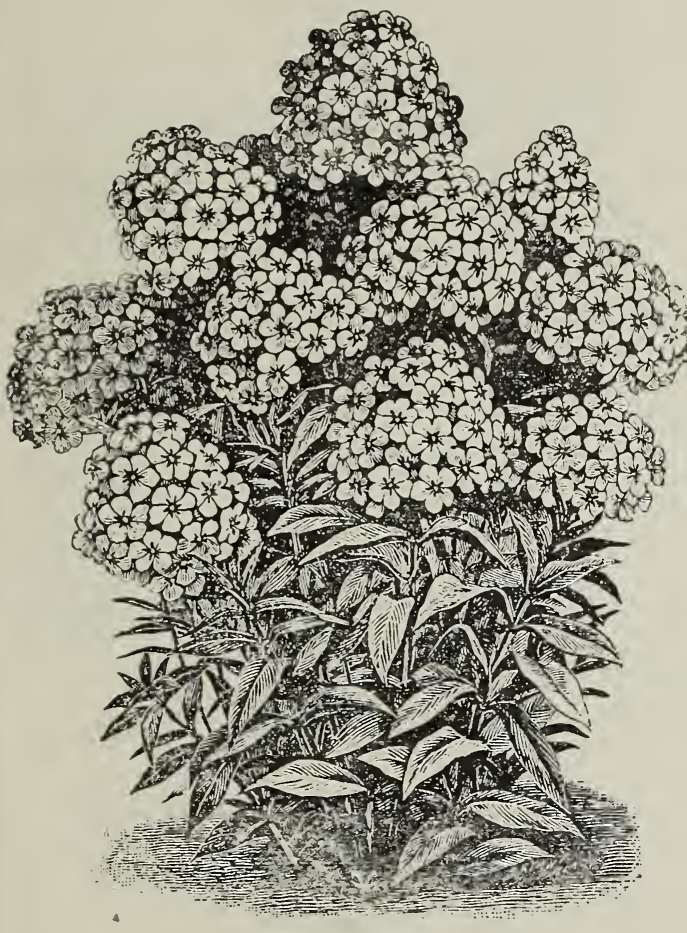

HARDY PHLOX
HARDY PHLOX

CHOICE PERENNIAL VARIETIES

Hardy Phloxes have long been so popular that it is rare to find a garden without a collection of at least a few of the many beautiful varieties now in cultivation. No plant is more attractive or more useful either for the adornment of the garden or for supplying cut flowers. The gardener's art has succeeded wonderfully in producing varieties which are marvels of beauty, both as to size of blossoms and variety, richness and delicacy of cnlor. To those not familiar with these plants we desire to say that they are perfectly hardy, and succeed well in almost any kind of soil. Small plants are usually selected to start with, as they increase rapidly in size, not in height so much, which is from two to three feet, but in the number of flower stems, which multiply year after year

Albatros-Pink, shaded purple.

Andreas Hoffer-Pure white.

Bacchante-Dark crimson, salmonpink eye.

Beranger - White, suffused with pink, rosy-lilac eye.

Boule de Feu--Bright salmon, crimson eye.

Bridesmaid-Pure white, crimson eye.

Comte-Dark Red.

Any of the above, each $10 \mathrm{c}$. or set of seven $50 \mathrm{c}$, post paid

\section{HARDY ORNAMENTAL SHRUBS}

\section{SNOWBALLS}

Japan Snowball--(Viburnum plicatum)--This Japanese variety of the old fashioned Snowball is one of the most valuable of our hardy shrubs. It forms an erect, compact bush, six to eight feet high. It blossoms in early June, and for a long time is a solid mass of white. The plant is completely covered from the ground to the top of the branches with large balls of flowers, as white as snow. Bushes three feet high, each 35c.

Old Fashioned Snowball--(V. Sterilis)--Bushes two to three feet high. Each 35c.

\section{VIBURNUM}

Dentatum--May and June. A free flowering shrub, especially admired for the abundance of its scarlet fruits that cling to the branches a long time. Two to three feet. Each 50c.

Opulus-(High-bush Cranberry)-May. Spreading habit. Single white flowers borne in flat, imperfect clusters, followed by clusters of berries that cling to the leafless branches all winter. Three to four feet, each $50 \mathrm{c}$.

\section{RHODOTYPHUS}

Kerrioides - $A$ very ornamental shrub of medium size with handsome foliage and large single white flowers in the latter part of May. succeeded by numerous small fruits. Two feet, each 35c. 


\section{HARDY ORNAMENTAL SHRUBS-CONTINUED}

\section{SPIRAEA MEADOW SWEET}

Anthony Waterer-(New Perpetual-blooming Red Spirea)-A fine hardy, perpetualblooming shrub, particularly desirable for the lawn. Makes nice, round bushes, three feet high and wide; beginning to bloom almost as soon as planted; rosy red flowers in large. round clusters all over the bush. One to two feet high. Each $25 \mathrm{c}$, doz. $\$ 2.50$.

Van Hout tii-A splendid garden shrub, entirely hardy and one of the most beautiful of all; immense bloomers; pure snow-white flowers. This is the plant for the people. Bushes two to three feet high. Each 25c, doz. $\$ 2.50$.

\section{PHILADELPHUS, OR SYRINGA (MOCK ORANGE)}

Indispensable well known shrubs that are prized for their beautiful foliage and white flowers. The taller kinds flower profusely and nothing is finer in their season. Each $35 \mathrm{c}$.

\section{ALMOND, DOUBLE FLOWERING}

A desirable class of early-flowering shrubs blooming in early spring. The flowers are double and are either pink or white. Strong bushes two to three feet, pink or white, $35 \mathrm{c}$.

\section{TAMARIX}

Shrubs of strong but slender, upright growth, clothed in foliage as light and feathery as that of the asparagus. Their delicate fringing flowers are usually some warm shade of pink or red, and very ornamental at the back of shrubbery border. Each 35c.

\section{CORNUS DOGWOOD}

Siberica-(Red Siberian Dogwood.)-A rare and remarkable variety with bright red bark in winter. Strong bushes three to four feet. Each $50 \mathrm{c}$.

\section{LILACS}

These old favorites are so well known that any description would seem superflous. Sufflce to say they are indispensable.

Persica-(Persian Lilac)-A very popular plant; flowers purple. Each 35c.

Vulgaris-(Common Lilac) - Larger foliage than the former; flowers purple. Each 35c. Alba-Flowers pure white. Each 35c.

\section{HONEYSUCKLES}

Chinese Sweet=scented Honeysuckle-A fine variety of vigorous growth; white and yellow flowers. A very fragrant and constant bloomer. Each $25 \mathrm{c}$.

Evergreen Sweet=scented Honeysuckle-A hardy, vigorous grower; blooms nearly all the sezson; deliciously fragrant; flowers buff, yellow and white; very desirable for veranda and trellis-work. Each 25c.

Red Coral Honeysuckle- $\AA$ hardy, rapid grower, suitable for rock-work, etc. Bright red, trumpet shaped flowers. Each 25c.

\section{HYDRANGEA (PANICULATA GRANDIFLORA}

One of the finest hardy shrubs in cultivation. The flower trusses are immense heads from nine to twelve inches in length and nearly as broad. Color purest white. changing to deep pink as the season advances. It blooms in July, at a time when no other shrub is in flower. and remains beautiful until destroyed by frost. Hardy as a lilac bush. The plants we offer will all bloom the first season. Prices according to size. First size, each $50 \mathrm{c}$.

\section{JAPANESE CLAMATIS (CLEMATIS PANICULATA)}

This is by far the best of all the Clematis of the small flowered class. A vine of very rapid growth, quickly covering trellises and arbors with handsome, clean, glossy foliage. which is of that healthy green color that so few of this class of plants possess. The flowers are pure white, borne in immense sheets, almost completely hiding the foliage, and of the most delicious fragrance. It flowers in September, when few other flowers are in bloom. The extreme rapidity of growth, the showy foliage, beautiful fragrant flowers, and hardiness serve to make this one of the choicest of recent productions. Prices: One year, each 25c. two years, each $35 \mathrm{c}$, three years, each 50c.

Clematis-Jackmanii Purple, each $50 \mathrm{c}$ and $75 \mathrm{c}$. 


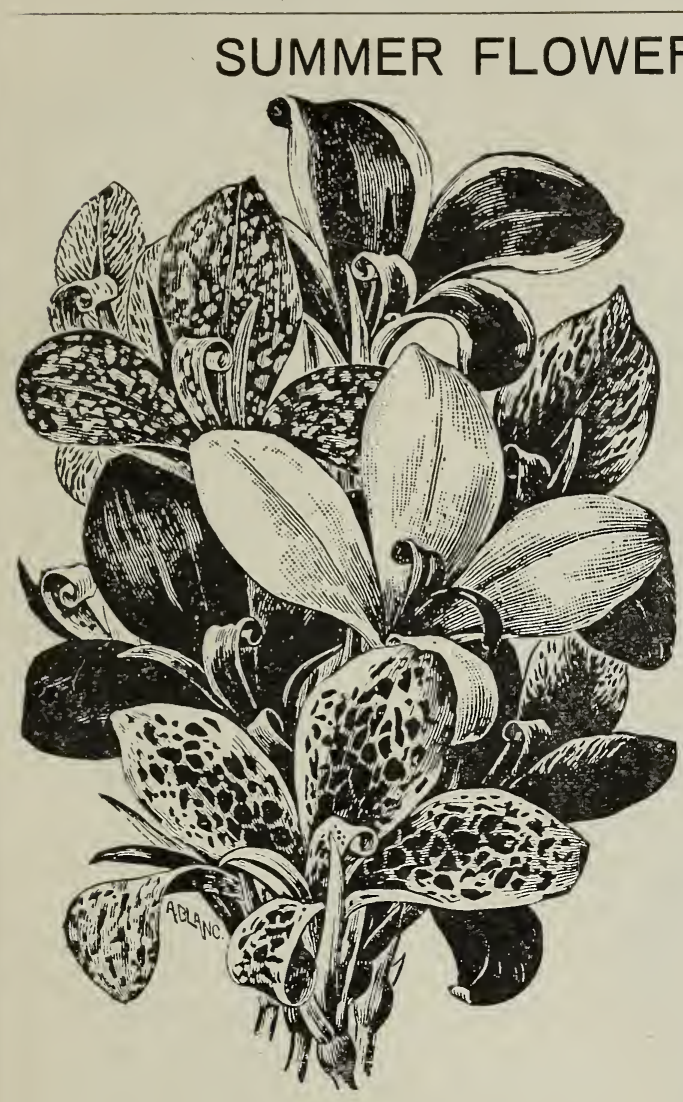

CANNAS

Many of the most showy, attractive and inexpensive and easiest grown of all summer and autumn flowers are contained in this important class. There are scarcely any other flowers that can compare with the noble and brilliant spikes of the Gladiolus, the grace and elegance of the Lily, the purity and sweetness of the Tuberose, the majestic foliage of the Caladium.

Bulbs for spring planting require scarcely any care, and quickly make a gorgeous display, while the bulbs can be kept over winter. and year after year will return a hundred fold in beauty and satisfaction the trifling expense of the original cost.

\section{CANNAS}

Canna tubers should not be put in the ground until the soil has become warm. They commence blooming in June and continue until late in September. Every shoot bears a flower, and these shoots are being constantly produced throughout the blooming season.

Canna Robusta_Of luxuriant dark bronze foliage. Six to eight feet. Fine for hedge or background. $5 \mathrm{c}$ each. $50 \mathrm{c}$ doz.

\section{GLADIOLUS}

The Gladiolus is the most attractive of all the summer flowering bulbs, and deserves a place in every garden, as it it is sure to flower and do well with very little care.

Set the bulbs from six to nine inches apart, and about four inches deep. Plant from middle of April to first of June. It is a good way to plant two or three different times, ten days to two weeks apart. This will give a succession of blooms from July to November.

I MERICA-soft flesh-pink. PRINCFPS-Scarlet. MRS. FRANCIS KING-Light scarlet, new. AUGUSTA-Pure while wi h blue anthers. Blue Jay-Dark blue. I(1c earh. $\$ 1.00$ per coz. posipair. FI N MIXED-4 for $10 \mathrm{c}$, doz. $25 \mathrm{c}$. WXTRA FINE MIXED-3 for 100 , doz. 35e. LEMONIE'S HYBRID MIXED-Each 5e, doz. $50 \mathrm{c}$.

\section{CALADIUM ESCULENTUM}

Elephants Ears - One of the most effective and easily grown plant for the lawn or flower border. Will thrive in any ordinary garden soil, but to get the best results plant in rich soil and give plenty of water. With such treatment a select size bulb will make a plant about five feet high with leaves three feet long and twenty inches wide. First size bulbs 15c. doz. \$1.50.

\section{MADERIA VINE}

A rapid growing, graceful vine, with smooth waxy, dark green leaves, and dainty recemes of tiny fragrant white flowers. Will grow in almost any situation. Two for $5 c$, doz. $25 \mathrm{c}$.

\section{CINNAMON VINE}

In midsummer the plant is covered with a brilliant, glossy foliage and an abundance of fragrant flowers. Extra large roots, $10 \mathrm{c}$ each, three for $25 \mathrm{c}$, doz. $\$ 1.00$.

\section{TUBEROSES}

One of the best known and most easily grown summer flowering bulbs. Easily recognized by its exquisite fragrance and bezutiful flower spikes which are borne on long stems, making it an admirable cut flower for house decoration. Three for $10 \mathrm{c}$, doz. $35 \mathrm{c}$. 


\section{DAHLIAS}

In recent years owing to the introduction of many beautiful new varieties originating in this country, the Dahlia is a great favorite everywhere. Nor is this difficult to understand considering that the Dahlia is easy to grow. commences to bloom in July and are thereafter a mass of bloom until cut down by frost.

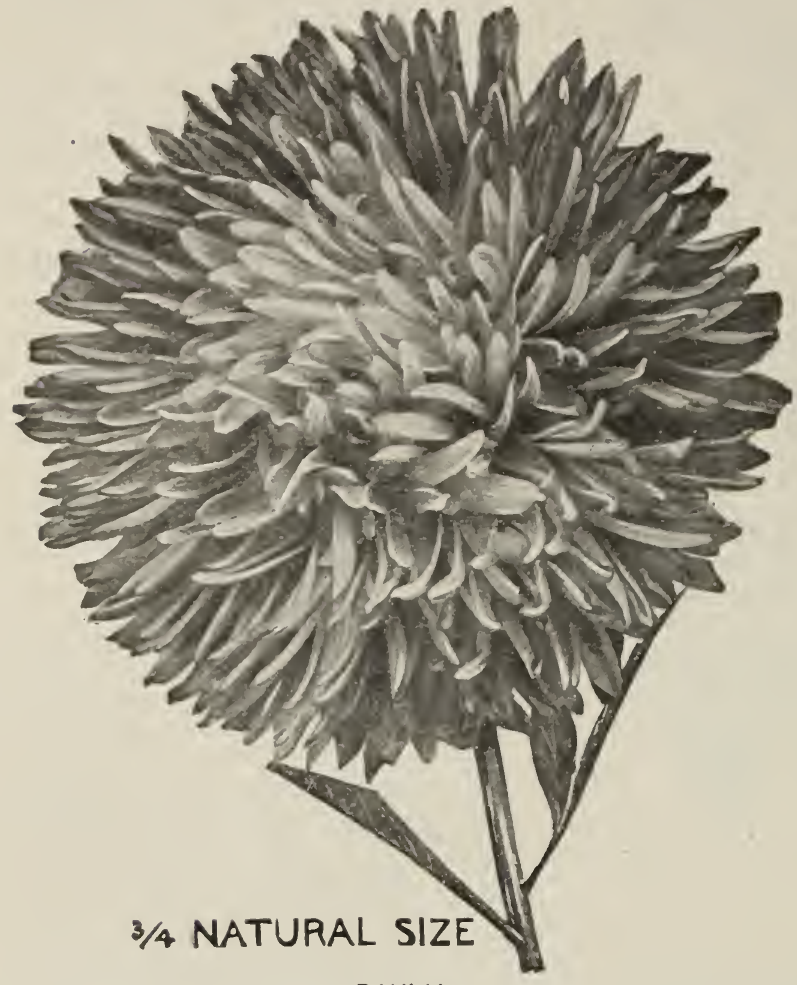

A. D. Lavoni - Beautifu soft pink. with quilled petals.

Gem-Deep crimson. Very double and a good bloomer.

Goliath-Deep garnet red. long stem.

Henry Sherber-Salmon large and fine.

Nymphaa - Light pink. long stems, fine to cut.

Mrs. Winters-The very best pure white.

Kriemhilde-Exquisite shel pink, shading to white.

Paul's Scarlet Brightest scarlet.

Queen of Yellows - A beautiful clear yellow.

Snow -.. White, profuse bloomer.

Sylvia - Flowers white, shaded to soft pink.

Twentieth Century - An intense rosy-crimson tipped with white.

Lyndhurst-The best bright scarlet with long stems.

Red Indian - Deep coralred, long stem, very large.

$\mathbf{W m}$. Agnew-Best intense glistening scarlet crimson. Immense size.

Clifford W. Bruton The finest canary yellow.

Mrs. Hartong Splendid bronze, new and large.

Salmon Queen-Very large, soft salmon.

Progress-Soft rosy lake, beautifully penciled and spotted glowing crimson.

Cathrine Duer-Extra large, scarlet-vermillion.

\section{SPECIAL OFFER No. 1}

Price each $15 \mathrm{c}$, four for $50 \mathrm{c}$, twelve for $\$ 1.50$, postpaid.

\section{SPECIAL OFFER No. 2}

The following superb Dahlias at $10 \mathrm{c}$ each, or set of seven, postpaid for 50c.

American Beauty-Color like an American Beauty Rose.

Water Lily-Pink and resembles a Water Lily.

Golden Queen-Golden yellow and free bloomer. lific.

Crimson King-Ox-Biood red, very pro-

Bride $-A$ good white.

Salmon Prince-A good clear salmon.

Boquet Royal-Rich crimson tipped with white. 


\section{"FIELD GROWN" TWO-YEAR-OLD HARDY HYBRID PERPETUAL ROSES}

THE HYBRID PERPETUALS are considered the most valuable of all Roses. They are chiefly distinguished by their vigorous growth and fine, large flowers and for being entirely hardy. They are particularly valuable for permanent beds or borders in the northern and middle states. Many of them flower the entire summer; others flowering through the month of June and again in August and September. The flowers are large, often measuring five to six inches in diameter; very fragrant and of all the colors known to the rose. If you wish to enjoy a glorious sight, set out a row of these roses in a trench filled with manure and strong soil (mixed together), and you will be repaid. Set these plants fifteen to eighteen inches apart. When planting, care should be taken to set plants deeply, planting them at least two inches above the first joints or branches and pounding the soil firmly around the roots. Cut shapely and keep well trimmed and the dead wood removed.

\section{MADAM PLANTIER}

This grand variety, when once planted, is as permanent as a Hydrangea. It is hardy as an Oak, and for outdoor planting it is the best white Hybrid Perpetual. We recommend it for cemetery planting, because of its permanency. Flowers are pure white. very large and double; it is a profuse and continuous bloomer. Good white, hardy roses are scarce-this is one of the very best. Each $35 \mathrm{c}$ and $50 \mathrm{c}$.

\section{BEST HARDY GARDEN ROSES}

American Beauty-This variety has been rightly described as an ever blooming Hybrid Perpetual. The flowers are very large and double; color, a deep rich rose. The fragrance is delightful. Each shoot produces a bud.

Anna de Diesbach-Bright rosy color; very large and showy; particularly fine in bud; flowers slightly cupped; a vigorous grower; one of the best.

Baron de Bonstetten-Dark red, almost black; very large, double, fragrant flowers.

Clio-The flowers are perfection in form. Color, delicate satin blush with a slight shading of rose pink in the center. Very free blooming.

General Washington-This splendid rose is one of the best; color, bright shining crimson; flowers large and perfectly double; blooms almost constantly.

Kaiserin Augusta Victoria-One of the best white roses for summer bedding. Large flowers produced in great profusion all summer. Should be protected in winter.

Margaret Dickson-The flowers are of the purest white, of extra large size and of grand substances. Free flowering and strong grower.

Madam Charles Wood- $\bar{A}$ continuous bloomer of dwarf compact habit. Flowers are large and very double, of deep crimson shade.

Paul Neyron-Deep shining pink. Flowers often five inches in diameter. It is a good, strong grower; almost thornless. Considered the finest pink rose.

Prince Camille de Rohan-Velvety crimson, shaded scarlet.

Perle des Blanches--A finely formed pure white rose.

General Jacqueminot-Rich velvety crimson; very fine.

Price-Extra strong, two year old field grown plants, each $35 \mathrm{c}$, dozen $\$ 3.00$.

\section{BEAUTIFUL CLIMBING ROSES}

Crimson Rambler-One of the striking characteristics of this Rose is its remarkable color, which is of the brightest crimson and remains so to the end. The flowers with which the plant is covered are produced in large trusses of pyramidal form and carrying thirty or forty flowers, which remain on the plant a long time. The foliage is bright green and glossy and contrasts finely with the bright crimson of the Rose. The plant seems to be as hardy as the old Prairie Queen. Every garden should contain this grand Rose. Price, strong one year old plants, each $25 \mathrm{c}$, selected two year old plants, each $50 \mathrm{c}$.

The Philadelphia Crimson Rambler-It differs from the Crimson Rambler in two important particulars. First, the color is brighter, deeper and more intense. Second, the flowers are perfectly double to the center. It is a strong, healthy grower, free and abundant bloomer. Two year old plants, each 50c.

Dorothy Perkins, New Rambler Rose-As hardy as a Crimson Rambler and same habit of growth. The flowers are about one and one-half inches across; are borne in clusters of from ten to thirty, and are very double; the petals are very prettily rolled back and crinkled. The color is a most beautiful shell pink and holds a long time without fading. Strong two year old plants, each 50c.

Prairie Queen-A favorite with everyone. If you want a Rose for your porch, this is the one. Color, bright red, changing as the flower opens to a deep pink. Each $35 \mathrm{c}$. 


\title{
FARM AND GARDEN TOOLS
}

\author{
A COMPLETE DESCRIPTIVE "IRON AGE" CATALOgUe SENT FREE ON APPLICATION.
}

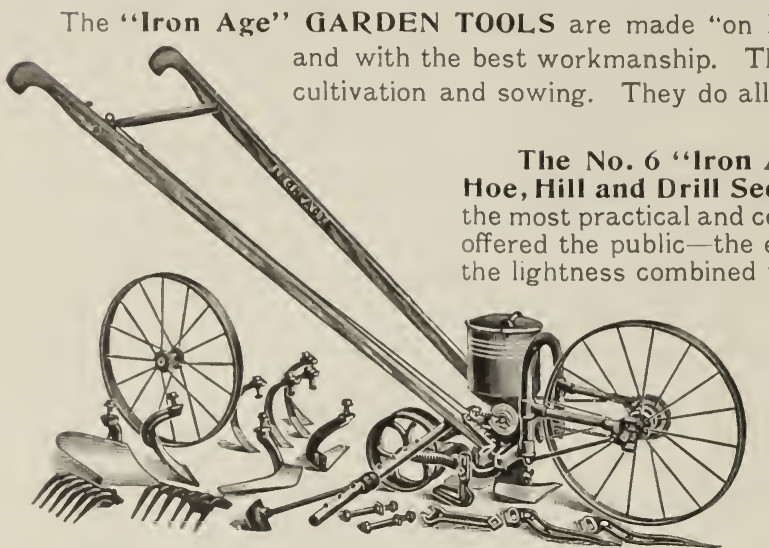

honor" from the best of material and with the best workmanship. They cover all the requirements of cultivation and sowing. They do all that garden tools can do.

The No. 6 "Iron Age" Combined Double Wheel Hoe, Hill and Drill Seeder-This tool is without questior. the most practical and complete combined garden tool ever offered the public - the ease and simplicity of adjustment, the lightness combined with great strength, the accuracy

by which it drills or hills the seed, and the small amount of power required to operate it. are the important features. The wheel is made of steel 16 inches high, the frame of pipe, coupled to malleable castings. In each form, whether a Seed Drill, a Double Wheel Hoe, or a Single Wheel Hoe, it is equal to any tool or tools made especially for the one purpose. It places the seed in drills or in hills at $4,6,8,12$ or 24 inches apart. Complete as in cut. Price \$12.00.

No. 1 "Iron Age", Double and Single Wheel Hoe-Wheel Hoe form of the No. 6. One great advantage which this Double Wheel Hoe possesses is that it can be made into a practical Single Wheel Hoe in a moments time. As a Double Wheel it may be used astride the row and thus cultivate both sides of the row at the same time.

The wheels are 16 inches high, enabling the Wheel Hoe to run easily and without yielding to the inequalities of the soil as a low wheel will do. The frame being made of pipe coupled to malleable castings, gives great strength together with lightness. Price complete, \$7.00. A Seed Drill attachment may be applied for sowing in rows only, or sowing both in rows and hills. \$4.00 and $\$ \mathbf{5 . 0 0}$ respectively. This tool with side hoes only (Iron Age No. 3.) Price \$4.25.

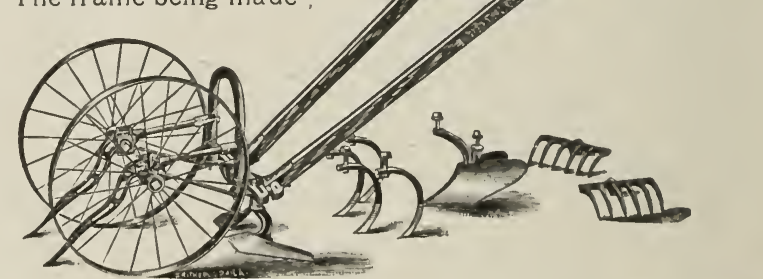

No. 20 "Iron Age" Single Wheel Hoe-The frame of this tool as in all Iron Age combined tools, is made of pipe coupled to malleable castings, thus rendering them light and strong. A pair of side hoes, a set of cultivator teeth, a pair of rakes and a land side plow are furnished with this tool. Price complete. $\$ 6.00$; as with the No. 1 a Seeder attachment may be added at any time.

No. 21 Plain, (Hoes Only)Price $\$ 4.00$.

Ask for Catalogue of "Iron Age" Tools, and price on Special Tools.

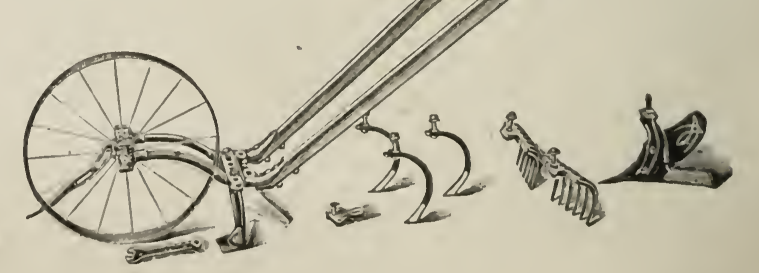




\section{THE No. 6 "IRON AGE"}

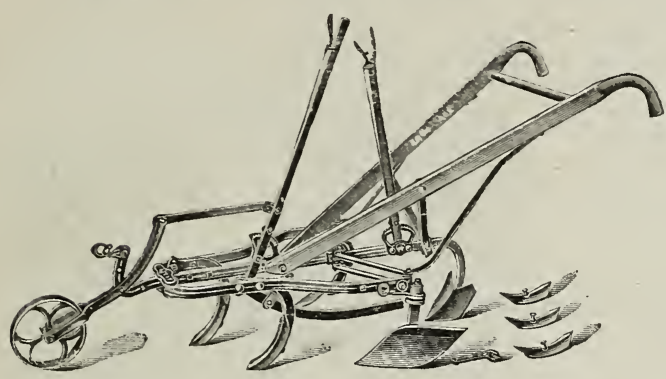

HORSE HOE AND CULTIVATOR

\author{
PRICE AS IN CUT \\ $\$ 7.50$
}

The Frame of this tool is high and long, therefore it runs steady and with excellent clearance of trash. The Horse Hoe standards carry the cultivator teeth as shown, instead of using an additional pair of cultivator standards.

The Horse Hoe Standards are of heavy solid steel and are attached to the bars by means of malleable iron ratchet castings, thus making a very firm connection and one capable of withstanding severe shocks without injury.

The Ratchet Castings are constructed so as to give easy and numerous adjustments to the side hoes, not only sideways but in angle of pitch. This adjustment also permits of the side hoes being entirely reversed for hoeing, or for covering purposes, with point forward, as shown in cut, they can be quickly changed from side to side. Although our No. 6 Horse Hoe, when used as a cultivator expands to a width of 30 inches, and closes sufficiciently for ordinary purposes, the hoe steels, if necessary, can be brought into immediate contact with each other by placing the ratchet casting in a reverse position on the inside of the side bars. In this shape the tool is capable of doing excellent work, opening furrows for manure and other purposes. By the use of this Lever Expander the tool, as a cultivator, can be instantly changed while the motion from the extreme width of 30 inches to 14 inches as its narrowest. Or, the casting of the Hoe Standards can be placed on the inside of the frame and it can be used as a cultivator as narrow as 11 inches.

The Lever Wheel is also extremely simple, the lever handle being of steel, the castings malleable and is attached to the forward part of the Horse Hoe, the two bolts of the hingeplates passing through the malleable ratchet piece.

\section{BROADCAST SEED SOWER}

A PRACTICAL MACHINE FOR SOWING CORRECTLY ALL KINDS OF FARM SEEDS

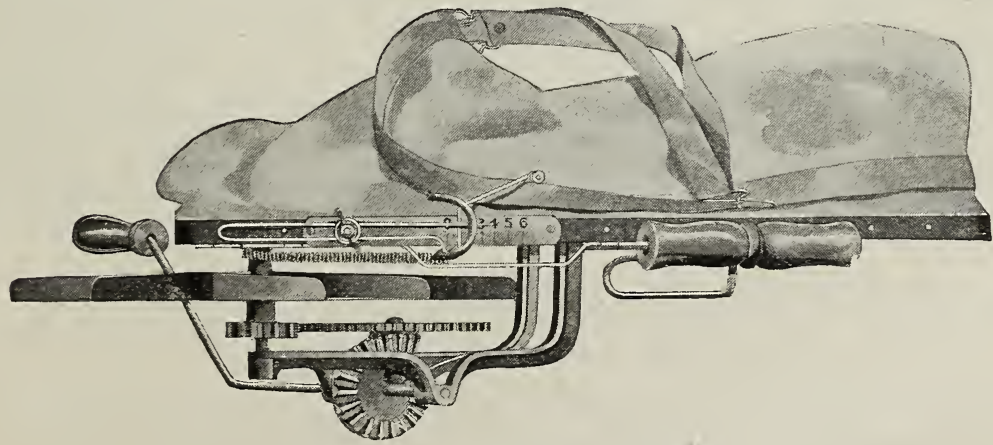

Perfect in distribution. Mechanically constructed. Neatest and most simple. Has Automatic Cut-Off and Regulator. Lightest running of all Seed Sowers. Strongest in construction. The lowest priced Standard Machine manufactured. Price \$2.00. 


\section{NEW BRANDT SPRAYER}

The latest of all devices for exterminating. all kinds of injurious insects on plantations with only one-tenth the labor, cost and time of any other method known. with far better efficiency.

No waste of time by stopping to pump it ahead. Can be done as the operator goes along.

For distributing Paris Green, Bordeaux Mixture, Paris Green and Bordeaux Compound, Spanish Pink, etc.

Will spray one or two rows of potatoes at a time as fast as a man walks.

Will spray a row a mile long with only one filling of three gallons.

Will spray from fifteen to twenty-five hills of potatoes with each stroke of the pump.

Manifold uses for Farm, Orchard, (iarden or Field. Invaluable in Potato and Tomato fields; Gooseberry, Currant and Rose bushes. In Garden on Cabbage. Celery Cucumbers. Squash. Cauliflower, etc. $\$ 5.50$ and $\$ 6.50$.

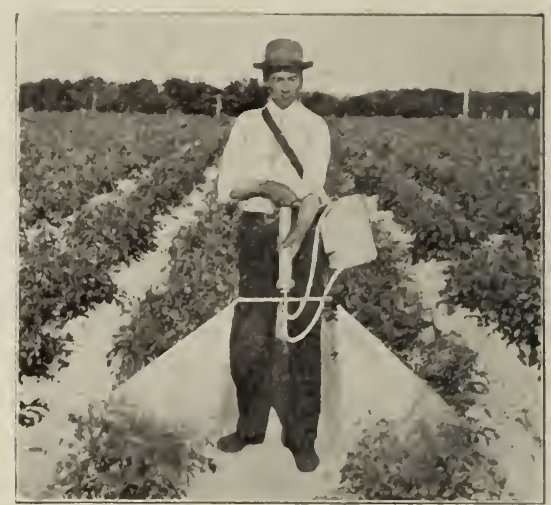

\section{GLASS TANK SPRAYER}

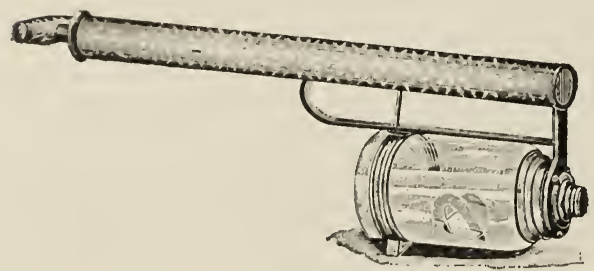

Is vastly different from any other sprayer of this class on the market. It is said by all who know its construction and advantages to be the simplest, most durable. and best hand sprayer ever made. Each 75c.

\section{INSECTICIDES}

Have you ever thought of the loss of profit and labor occasioned by the ravages of insects? Use reliable and tested Insecticides and save this annoyance.

To=bak=ine liquid is a concentrated solution of pure nicotine, making it the most powerful insecticide known for spraying, and without doubt the cheapest insecticide on the market. Bottle $15 \mathrm{c}$ and quarter pt. 60c,

Whale Oil Soap-Used for washing plants and in spray. Half lb. cake $15 \mathrm{c}$.

Sulpho Tobacco Soap -Excellent for freeing ferns and palms from insects. and used as a wash. Cakes $10 \mathrm{c}$ and $20 \mathrm{c}$.

Sure Shot - A fine powder good for all purposes. Used alike on both plants and animals and especially good to use on chickens and setting hens. $10 \mathrm{c}$ and $25 \mathrm{c}$ per box.

Slug Shot-A dust used on cabbage, cucumber and all vines. Five lb. package $30 \mathrm{c}$.

Paris Gireen One lb. 25c, five lbs. $\$ 1.00$. Subject to market change.

Fly Knocker kills every fly it hits and keeps others from alighting on your horses or cows. Used as a spray. Qt. 35c, half gal. 60c, gal. \$1.00.

\section{THE FRENCH BORDEAUX MIXTURE}

\section{IN FINE PULP OR LIQUID) FORM}

Ready for immediate use. Works freely without clogging in any sprayıng machine. To be diluted 25 to 50 times with water and sprayed. This article is so well made that it covers evenly a very large leaf surface, and the even distribution. in ininute mass, is what does the real protective work. The uniformity of its consistence permits of very fine spray and consequent large economical distribution of a small quantity evenly over a large area of surface. It sticks effectively. Qt. 40c. 


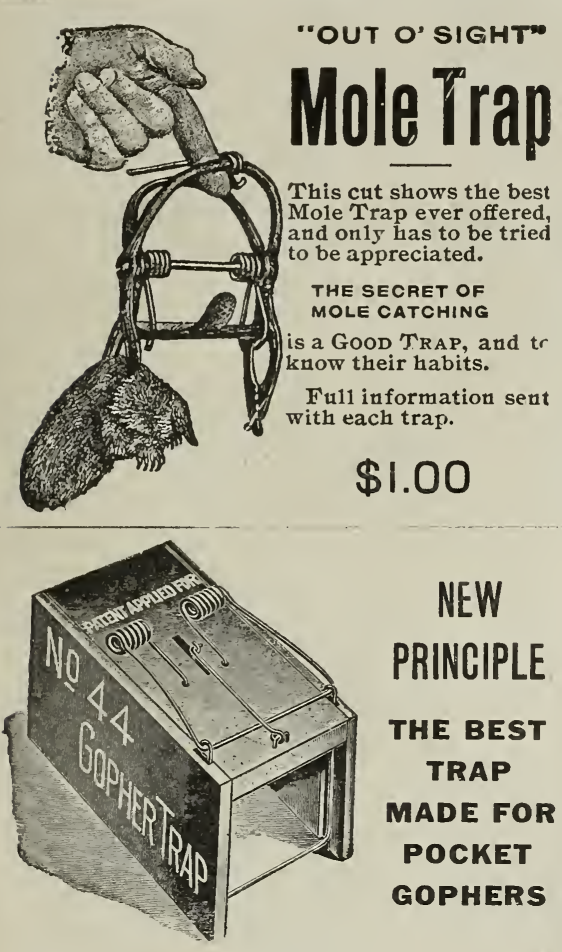

When properly set will catch 19 out of 20 . No danger and easy to set; sure catch. Full directions with each trap. Price 25c.
Corn Planter, "The Eagle"-This is a rotary Planter, having three different sized plates, which can be put in or taken out as needed in the easiest possible manner. One of the most popular. Each \$1.50.

Fork-Digging or spading; angular tines, each $65 \mathrm{c}$.

Trowels, Steel-One solid piece of steel and will outwear all others; each 50c; postpaid, each 60c.

Eureka Weeder-The best little hand Weeder for loosening soil around plants that we know of. $25 \mathrm{c}$.

Steel Bow Garden Rakes-Does not break in the center; 12 teeth, 40c: 14 teeth. $50 \mathrm{c} ; 16$ teeth, $60 \mathrm{c}$.

Dandelion Puller-This is the best Dandelion Puller in the market. It is made of best steel; after an English pattern. $25 \mathrm{c}$.

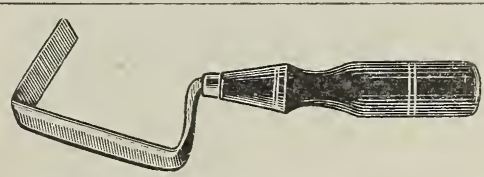

Lang's Hand Weeder-It is, in our opinion, the best Weeder made. It's special advantage over all other Weeders of this class is that it has a band which passes over the fingers, which, when the tool is not in use, gives full use of the hand for pulling weeds and thinning out plants, without laying down the tool. Price 25c: $\$ 2.50$ per dozen.

\section{POULTRY AND PIGEON SUPPLIES}

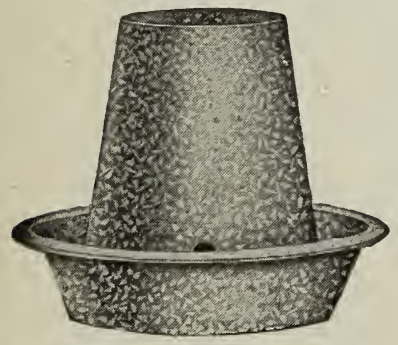

SANITARY DETACHABLE FOUNTAIN

Chickens can drink all around; easily cleaned, 2 quart $30 c, 3$ quart $40 c$.

We handle a complete line of Poultry Supplies of the best quality. Prices are subject to important market changes. We shall be glad to name special figures on large lots.

Mica Crystal Girit-This has proved to be the best on the market. It is hard and sharp, instead of grinding, smooth like an ordinary stone. Price $10 \mathrm{lbs} .15 \mathrm{c}$, 25 lbs. $35 \mathrm{c}, 100$ lbs. $\$ 1.00$.

Crushed Oyster Shell-This is a most important article for the poultry yard, and should be supplied to the fowls liberally. Price 10 lbs. 15c, 25 lbs. $35 \mathrm{c}, 100 \mathrm{lbs}$. $\$ 1.00$.

Crushed Bone-Of the best quality, being made from fresh bones. Price $10 \mathrm{lbs} .40 \mathrm{c}, 100 \mathrm{lbs}$. $\$ 3.00$.

Fine Bone Meal-Ground fine for feeding small chickens, also used as a lawn fertilizer. Price 10 lbs. $30 \mathrm{c}, 100$ lbs. $\$ 2.50$.

Rust's Egg Producer-Greatly increases egg production and makes poultry keeping the most profitable of rural pursuits. Price, 1 pound box $25 \mathrm{c}$, if by mail $45 \mathrm{c}, 2 \frac{1}{2}$ pound box 50 c, if by mail $\$ 1.00$.

Rust's Havens' Climax Condition Powder-Cure for Cholera and Gapes. It is just what every owner of poultry needs to save his fowls and keep them healthy. Price, $13 \mathrm{oz}$. box $25 \mathrm{c}$, if by mail $40 \mathrm{c} ; 32 \mathrm{oz}$. box $50 \mathrm{c}$, if by mail $85 \mathrm{c}$. 
Rust's Havens' Roup Pills-For Roup. Colds. Catarrh. Pigeon Disease. etc. Box of 48 pills 25c; box of 250 pills $\$ 1.00$. Mailed on receipt of price

Germozone for Poultry Diseases-Roup, Canker. Cholera. etc. Price 50c

Conkey's Roup Cure - It is a positive cure for all forms of this disease. We Guarantee this. If it should fail, your money will be refunded no questions. just money. It is placed in the drinking water. the fowl takes its own medicine without knowing it. Price 50c.

Poultry Marker - This is a convenient little spring punch for marking chickens, by making a small hole in the web of the foot. Each 25c. postpaid.

Leg Band - Made of soft, pliable aluminum band. which is far superior to any other material. Numbered with plain figures. Price $15 \mathrm{c}$ per dozen: $85 \mathrm{c}$ per 100. postpaid.

Glass Nest Eggs - Each 5c: per dozen 35c; four dozen \$1.00.

Medicated Nest Eggs-Each 5c: per dozen 50c.

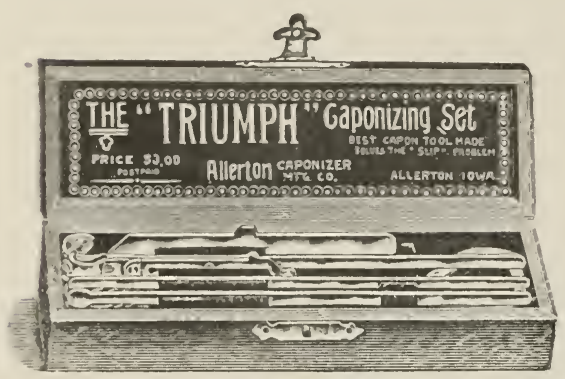

\section{The "Triumph" Caporizing Set}

There is no doubt in the minds of up-to-date poultrymen as to the advantages of caponizing. Caponizıng does away with the troublesome cockerei, and transforms him into a tranquil, majestic fowl moving at leisure about the yard and only growing fatter and heavier every day. The operation is very simple, and with a "Triumph Caponizing Set" any boy of 12 years of age can perform it with safety and thoroughness.

\section{PRICES:}

Set in plush-lined. cloth-covered. . . . . . . . . . . . . . . . . . \$3.00

Set in polished hard wood box....................... 2.75

Set in Japanned wood box

We pay transportation charges within the United States.

Chamberlain's Perfect Chick Feed is the original dry chick feed. Hundreds have used it from our store, and all commend it in the highest terms. $100 \mathrm{lb}$. sacks $\$ 2.75$.

Beef Scraps - These are pure, sweet and free from taint, and are fine ground. $100 \mathrm{lb}$. sacks \$3.00, or 4c per pound.

Meat Meal-Causes the young bird to feather quickly. grow fast and mature early. It is fine for moulting fowls. $100 \mathrm{lb}$. sack $\$ 3.00$. or $4 \mathrm{c}$ per pound. price.

Kaffir Corn - A fine feed for both pigeons and fowls. Sold at market

Alfalfa Meal-Supplies the green feed in winter for Chickens. Ducks. Pigeons or Geese. Sold at market price.

Canada Peas-Small green, for Pigeons. Sold at market price.

Granulated Charcoal-Fine for all birds. Made for feeding purposes, not for fuel. Sold in bulk at $\$ 3.00$ per 100 pounds.

Hemp and Sunflower Seed are fine to give the bird fine plumage. Sold at market price.

:The above quotations are subject to market changes. 


\section{How are Your Horses, Dong and Pèts?}

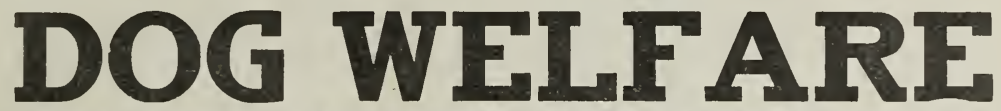

OR
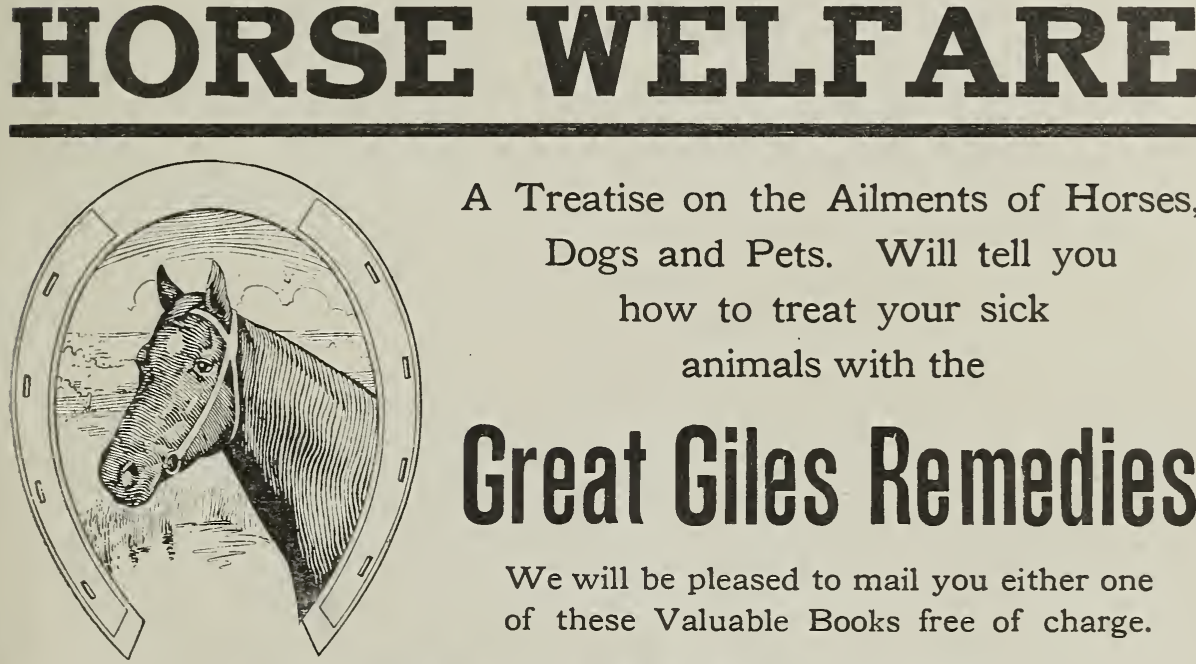

A Treatise on the Ailments of Horses,

Dogs and Pets. Will tell you

how to treat your sick

animals with the

\section{Great Giles Remedies}

We will be pleased to mail you either one of these Valuable Books free of charge.

\section{GIIES REIMEDIFS}

Have stood the most severe tests at the hands of conservative and discriminating animal fanciers for the past thirty years, and its wonderful efficiency as a preventive and cure for nearly every ailment, has abundantly proven its superiority over every other treatment.

We have successfully used "Giles" on our own sick dogs, and do not hesitate to recommend it. It gives universal satisfaction.

\section{GIIESS WIIII OUTRE}

DISTEMPER, WORMS, PNEUMONIA, MANGE, and in fact all ailments, as it works directly on the blood and removes the one cause, congestion.

Be Sure and Send for these Books:

DOG WELFARE oR HORSE WELFARE 


\section{INIEX}

\section{Vegetables}

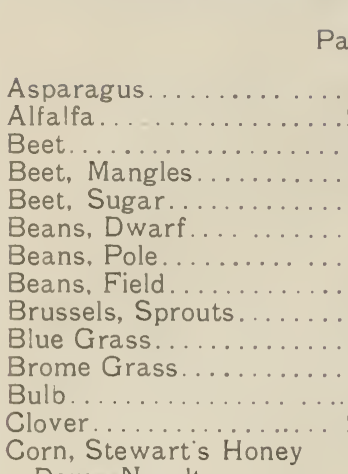

Dew - Novelty......

Corn, Golden Bantam.

Cabbage.

Celery

Celeriac............. 8

Cress............... 6

Carrot......... ... 8

Corn, Sugar............ 9

Corn, Field............20

Corn, Pop............20

Cucumber............. 8

Cucumber, Davis Perfect 3

Cane, Sorgum.........20

Egg Plant............... 9

Endive.............. 9

English Rye Grass......21

Fertilizer for Lawn and

Quantity to Use.........22

Grass Seed Mixture.....21

Grass, Lawn............22

Grass, for shady places . 22

Herbs................19

Kale..............99

Kohl-Rabi............... 9

Lettuce .............10

Leek..................10

Mushroom Spawn... . . . 10

Mustard.............10

Melon, Musk or Cantaloupe..............11

Melon, Water............ 11

Millet.............20

Onion................12

Okra..................13

Onion Sets . ........19

Orchard Grass ........21

Parsnip..............13

Parsley..............13

Pumpkin............15

Pepper..............15

Peas................. 14

Potatoes..............20

Radish, Stewart's White Wonder-Novelty..... 3
Page

Radish, Perpetual Crimson Globe Novelty.... 3

Radish.................. 15

Rhubarb............15

Rye Grass...........21

Rape, Dwarf Essex .... 20

Red Top . ......... 21

Slug Shot.... ......43

Spınach . ..........16

Salsify, or Oyster Plant...17

Squash ............17

Sweet Potato......... . 19

Turnip........... 17

Tomato..............18

Timothy............21

Vegetable Plants..... . 19

White Dutch Clover.....21

\section{Flower Seeds}

Aster, Gloria, or Buttonhole. ............23

Aster..............23

Alyssum, Sweet $\quad \cdots \cdot 24$

Amaranthus ..........24

Antirrhinum..........24

Ageratum : ......... 24

Butterfly Flower . ...24

Balsam.............24

Baloon Vine.... ......24

Balsam Apple.........24

Bachelors' Button . . ..24

Candytuft ..........24

Chrysanthemum........25

Calendula, Pot Mariagold 25

Coleus.............25

Cobaea.............25

Cosmos..............25

Cosmos-Novelty ...... 1

Canna.............25

Cypress Vine..........25

Calliopsis -Coreopsis ...225

Cockscomb ..........26

Cucumber, Wild........2 26

Carnations.... .....26 26

Campanula, Canterbury Bell...............26

Dahlia, Burbank's Novelty ............ . 2 Dahlia................27

Digitalis, Foxglove......26

Daisy, Double.........26

Daisy, New Shasta......27

Dianthus......... . . 27

Forget-Me-Not........27

Four O'Clock, Marvel of

Peru ............22

Gourds, Ornamental .....27

Gaillardia............28

Gypsophila .............2 2

Hollyhock. New Annual..28
Page

Hollyhock............28

Hyacinth Bean........28

Humulus ..........28

Heliotrope...........28

Hibiscus ...........28

Job's Tears..........28

Kochia, Burning Bush....28

Larkspur............28

Linum............ . 29

Lobelia....... . ...29

Mignonette.... . . ...29

Moon Flower.........29

Nasturtiums - Novelty .... 1

Nicotiana...........2929

Nasturtıums..........30

Poppy, Dwarf Shirley

Novelty............ 2

Poppy, Santa Rosa Novelty ... $\quad \ldots \ldots . .2$

Petunia, Howard StarNovelty......... . 2

Portulaca ..

Pansy................ 3]

Poppy................. 3]

Petunia..............32

Phlox ...............32

Ricinus.................32

Shrubs.............37

Sweet Peas Novelty.... 1

Sweet William..........32

Smilax................32

Salvia ........... 32

Sweet Peas............33

Verbena.................34

Wild Flower Garden.....34

Zinnia..............34

\section{Summer Flowering Bulbs}

Caladium........... 39

Hardy Parennial. . . . . . 35

Canna.................39

Cinnamon Vine.........39

Dahlias................40

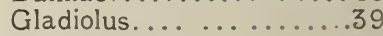

Maderia Vine.............39

Paeonies................37

Roses, Hybrid. ........41

Tube Rose............... 39

\section{Miscellaneous}

Farm and Garden Tools ..............4 42 and 43

Sprayers.............44

Insecticides...........44

Mole and Gopher Traps...45

Hand Garden Tools.....45

Poultry and Pigeon

Supplies. 


\section{LAWN SEED}

It will produce an even dense growth of permanent sward as early in the season as it is possible to do. This mixture contains no annual grasses for making quick show to the detriment of a good lawn, but only those of lasting value and hardiness, which when once established, need no reseeding for years. Our seed, which we know to be as pure as can be found anywhere, is of the best varieties, best suited for even and permanent growth; it is carefully cleaned, Lb. $35 \mathrm{c}, 3$ lbs. $\$ 1.00$.

\section{FOR SHADED LAWNS}

A selection of the fine grasses which thrive naturally under the shade of trees or buildings, or are suitable for light, sandy soil. This mixture was extensively used on the World's Fair grounds, where it gave splendid results. Lb. $35 \mathrm{c}, 3$ Ibs. $\$ 1.00$.

\section{QUANTITIES TO USE}

One pound for 400 square feet....... \$ 35 Five pounds for 2000 square feet.... 1.60 Ten pounds for 4000 square feet..... 3.00
Fifteen pounds for 6000 square feet. $\$ 4.30$ Twenty-five pounds for one-fourth acre 7.25 Fifty pounds for one-half acre........14.25

Kentucky Blue Grass-Many-prefer this to a mixture of grasses, and the fact cannot be denied that a lawn of Blue Grass only is magnificent. - It takes longer, however to get it established. Lb. 40c.

\section{White Clover-Extra choice seed. Lb. $40 \mathrm{c}$.}

Red Top Grass-Fancy clean seed. Where an immediate effect for one season is deaired there is none better than the Red Top Grass, as it comes up quickly and makes a beautiful lawn, but the grass is liable to winter-kill. Lb. czo.

\section{LAWN FERTILIZER}

Lawn grass is a very voracious feeder and will not thrive and hold its beautiful dark green and velvety appearance unless it receives a sufficient supply of suitable food. Because 80 few appregiate this fact is the reason there are so many poor, rusty-looking lawns. Stable manure is unpleasant to handle, ill looking and decidedly odorous, and it is also full of waste material. It contains weed seeds which are obnoxious and it often takes years to radicate the weeds, causing an unnecessary amount of labor. All these objections are obviated by the use of our Lawn Fertilizer. If the lawn is in fair condition it is only necessary to rake off the dead leaves and grass in the early spring and scatter broadcast over its surface, some of our Lawn Fertilizer with a little Lawn Seed over the thin spots, and thewerk is done.

Directions for Use-The first application should be made early in the spring, as soon as the frost is out of the ground, at the rate of twenty-five pounds of fertilizer to every 1000 square feet of lawn, evenly distributed. For seeding down a new lawn scatter double the amount, say fifty. pounds of fertilizer, broadcast on every 1000 square feet and rake it in thoroughly before sowing the seed. Lb. $5 \mathrm{c}$, eight lbs. $35 \mathrm{c}$, twenty-five lbs. $\$ 1.00$, fifty lbs. $\$ 1.75$, one hundred lbs. $\$ 2.75$. 


\section{IN A NUT SHELL-A Few Items of Interest}

The native home of the Dahlia is Central America and Southern Mexico. Its earliest known history dates back to 1657 , and at this date was called Acoctli by the Aztec Indians. Later its name was changed to Georgina, after Prof. Georgi of St. Petersburg, which name is still used in some of the German catalogs. Again the name was changed to Dablia, after Dr. Dahl, a Swedish botanist. The Dahlia in its native state is single. The first double forms appeared in 1814 and are credited to M. Donkelaar. The first double forms were of the types now known as SHOW and FANCY. The POM-

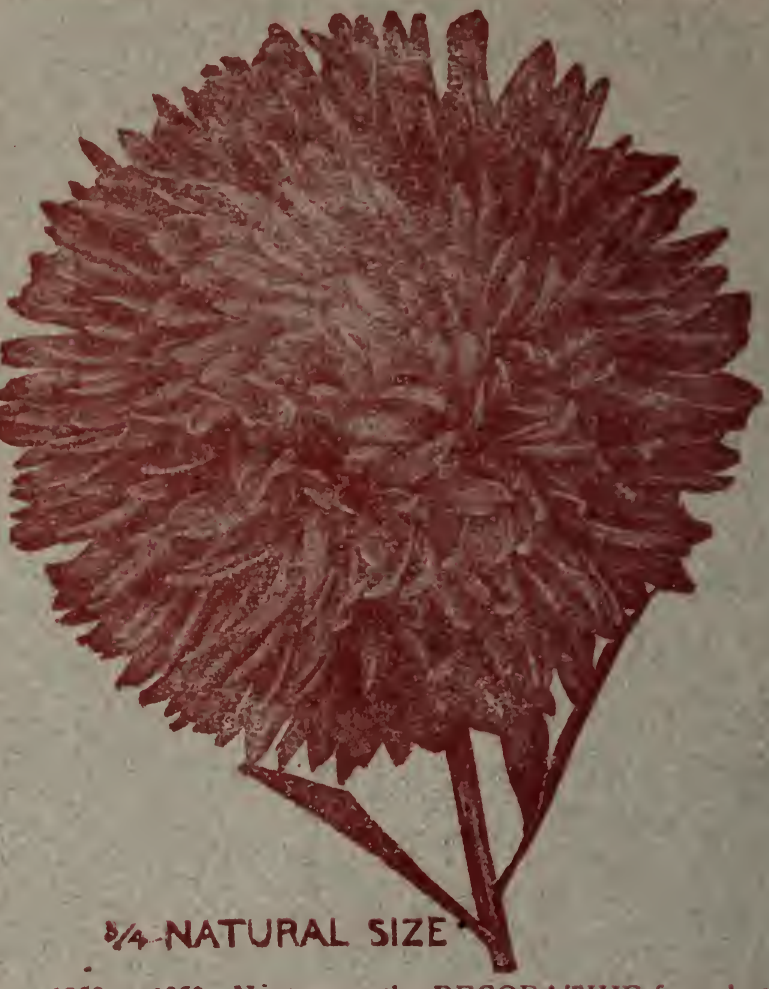
PON form appeared about 1858 to 1860 . Next came the DECORA'TIVE form, but its origin is not clearly defined, but probably dates back some forty or fifty years. The first CACTUS Dahlia originated in 1872, but was not placed on the market until 1880. It was named Juarezi after President Juarez of Mexico. This is the popular type of the present day and there are some 2000 named varieties of Cactus Dahlias today that have descended from the original Juarezi. The PEONY FLOWERED type is of quite recent origin, dating back but a few years.

\section{How to Grow and Care for Dahlias}

If possible plant in an open, sunny situation. Prepare the soil thoroughly by deep digging. Be moderate in the use of both manure and water. Never plant when the soil is wet. Lay the tuber flat on its side and cover it four inches deep, pressing the soil firmly on the tuber. Keep the soil loose and mellow by frequent hoeing, drawing the soil to a slight hillock around the plant.

Tall growing varieties may be kept fairly dwarf by pinching out the tip when the first shoot is six inches high. All varieties growing above four feet should be tied to stout stakes to hold them in position.

Keep all dead flowers trimmed off.

Dablia blooms keep much better if cut in the evening, about sunset, and the less foliage taken off with the flowers the better for both plant and flower. Is. green is desired, use some other green of better keeping qualities. 